\title{
Review
}

\section{Urban wastewater treatment plants as hotspots for the release of antibiotics in the environment: A review}

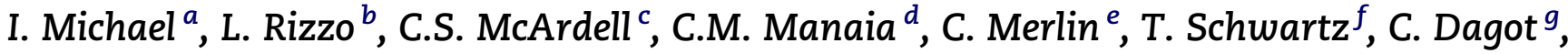 \\ D. Fatta-Kassinos ${ }^{a, *}$
}

${ }^{a}$ Nireas-International Water Research Centre, University of Cyprus, P.O. Box 20537, 1678 Nicosia, Cyprus

${ }^{\mathrm{b}}$ Department of Civil Engineering, University of Salerno, 84084 Fisciano (SA), Italy

${ }^{c}$ Eawag, Swiss Federal Institute of Aquatic Science and Technology, 8600 Dübendorf, Switzerland

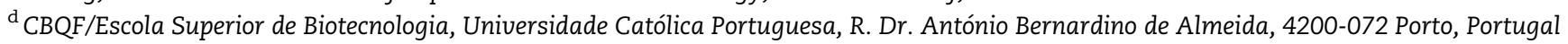

${ }^{\mathrm{e}}$ Laboratoire de Chimie Physique et Microbiologie pour l'Environnement (LCPME), UMR 7564 CNRS-Université de Lorraine, 15 Avenue du Charmois, 54500 Vandoeuvre-les-Nancy, France

${ }_{\mathrm{f}}$ Department of Microbiology at Interfaces, Karlsruhe Institute of Technology (KIT), Northern Campus, Institute of Functional Interfaces (IFG), D-76344 Eggenstein-Leopoldshafen, Germany

${ }^{\mathrm{g}}$ Université of Limoges, EA4330, GRESE, ENSIL, F87000 Limoges, France

\section{A R T I C L E I N F O}

\section{Article history:}

Received 20 June 2012

Received in revised form

15 November 2012

Accepted 17 November 2012

Available online 28 November 2012

\section{Keywords:}

Advanced wastewater treatment

Activated sludge

Antibiotics

Disinfection

Pharmaceuticals

Wastewater

\begin{abstract}
A B S T R A C T
Urban wastewater treatment plants (UWTPs) are among the main sources of antibiotics' release into various compartments of the environment worldwide. The aim of the present paper is to critically review the fate and removal of various antibiotics in wastewater treatment, focusing on different processes (i.e. biological processes, advanced treatment technologies and disinfection) in view of the current concerns related to the induction of toxic effects in aquatic and terrestrial organisms, and the occurrence of antibiotics that may promote the selection of antibiotic resistance genes and bacteria, as reported in the literature. Where available, estimations of the removal of antibiotics are provided along with the main treatment steps. The removal efficiency during wastewater treatment processes varies and is mainly dependent on a combination of antibiotics' physicochemical properties and the operating conditions of the treatment systems. As a result, the application of alternative techniques including membrane processes, activated carbon adsorption, advanced oxidation processes (AOPs), and combinations of them, which may lead to higher removals, may be necessary before the final disposal of the effluents or their reuse for irrigation or groundwater recharge.
\end{abstract}

(c) 2012 Elsevier Ltd. All rights reserved.

\section{Contents}

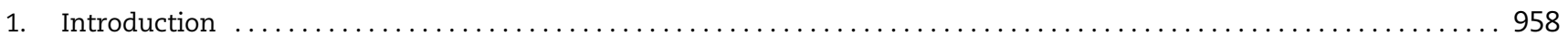

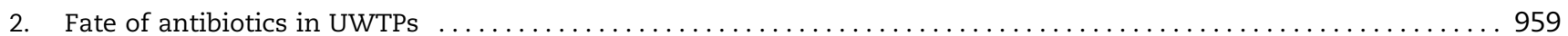

\footnotetext{
* Corresponding author. Tel.: +357 22893515; fax: +357 22895080.

E-mail address: dfatta@ucy.ac.cy (D. Fatta-Kassinos).

0043-1354/\$ - see front matter @ 2012 Elsevier Ltd. All rights reserved.

http://dx.doi.org/10.1016/j.watres.2012.11.027
} 


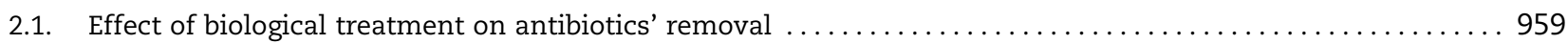

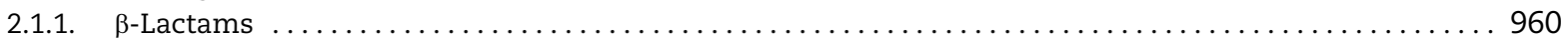

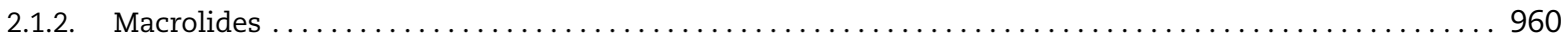

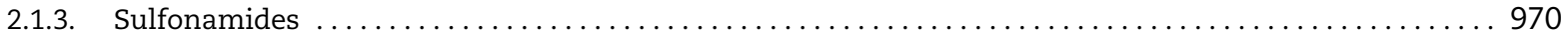

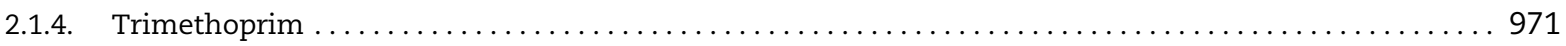

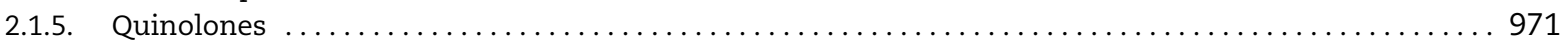

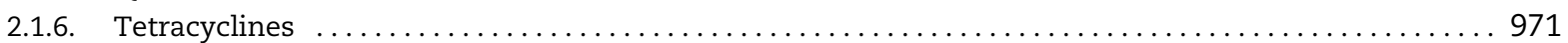

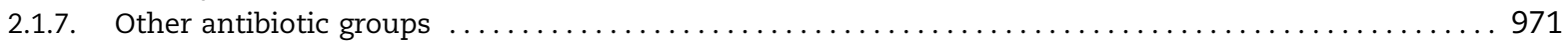

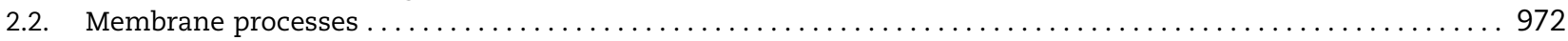

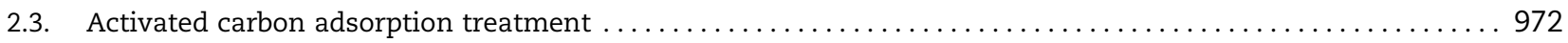

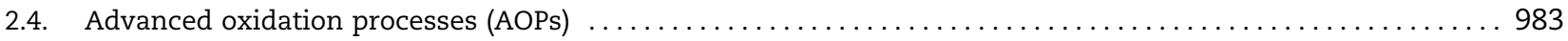

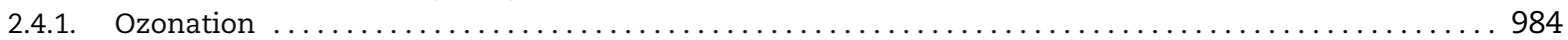

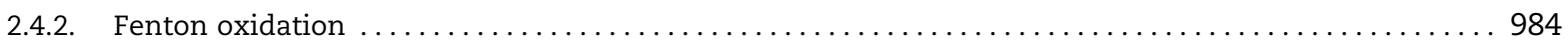

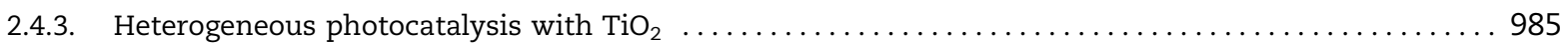

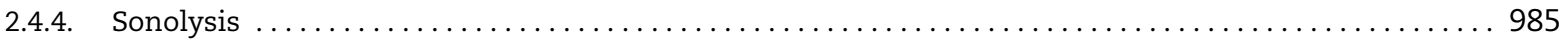

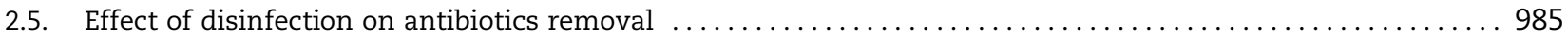

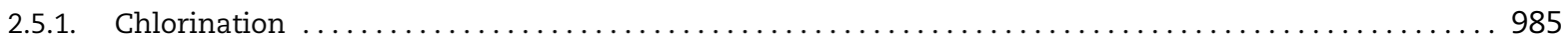

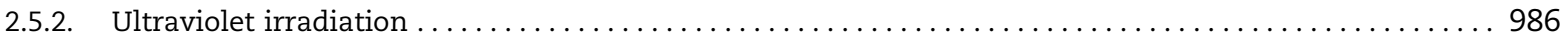

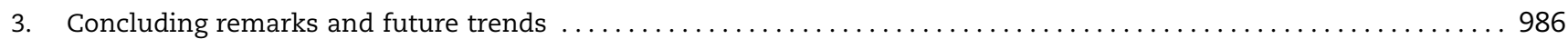

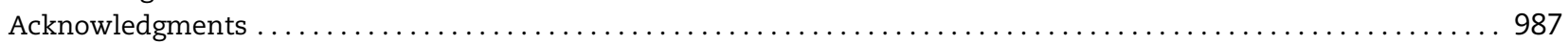

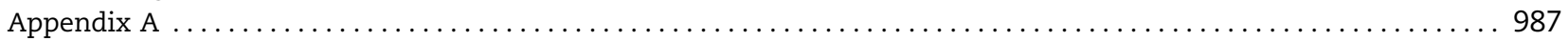

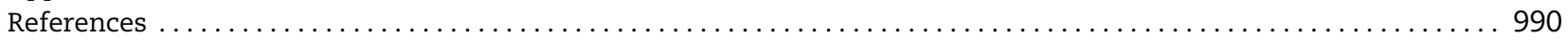

\section{Introduction}

During the last years, it is recognized that antibiotics constitute a new class of water contaminants of emerging concern with adverse effects on the aquatic life (Kolpin et al., 2002; Kümmerer, 2009; Fatta-Kassinos et al., 2011a). The generic term "antibiotic" is used herein to denote any class of organic molecule that inhibits or kills microbes by specific interactions with bacterial targets, without any consideration of the source of the particular compound or class (Davies and Davies, 2010). Investigations for the occurrence of various antibiotics in wastewater effluents have been conducted in several European countries (Jones et al., 2001; Heberer, 2002; Miao et al., 2004; Batt et al., 2007; Gulkowska et al., 2008; Kümmerer, 2009; Fatta-Kassinos et al., 2011a). Because of the intensive use of antibiotics for human (domestic and hospital use), veterinary and agriculture purposes, these compounds are continuously released into the environment from anthropogenic sources, such as urban wastewater treatment plants (UWTPs), which are considered as one of the main 'hotspots' of potential evolution and spreading of antibiotic resistance into the environment (Hirsch et al., 1999; Diaz-Cruz et al., 2003; Brown et al., 2006; Kümmerer, 2009; Czekalski et al., 2012; Le Corre et al., 2012). The presence of antibiotics in environmentally relevant concentration levels has been associated to chronic toxicity and the prevalence of resistance to antibiotics in bacterial species (Schwartz et al., 2006; Kümmerer, 2009).

The number of studies focusing on the chronic toxicological assessment of antibiotics in the environment is constantly increasing with the aim to bridge the various knowledge gaps (i.e. relevant endpoints to be considered in chronic bioassays) associated with these issues. Boxall (2004) and Kümmerer (2009) represent two comprehensive review articles regarding the ecotoxicity of antibiotics. Thomulka and McGee (1993) determined for example the toxicity of a number of antibiotics (e.g. novobiocin, tetracycline, chloramphenicol, nalidixic acid, ampicillin, streptomycin) on Vibrio harveyi in two bioassay methods. Almost no toxic effects were found after short incubation times when luminescence was used as an endpoint. However, in a long-term assay using reproduction as the endpoint, a toxic effect in environmentally relevant concentrations was detected for almost all the examined antibiotics. These results are in accordance with the observations of Froehner et al. (2000) concerning chloramphenicol, nalidixic acid and streptomycin. The chronic toxicity of several groups of antibiotics toward Vibrio fischeri is also presented in a study by Backhaus and Grimme (1999). The chronic bioluminescence inhibition assay was shown to be sensitive against many of the high volume antibiotics used for veterinary purposes and in aquaculture. Furthermore, exposure to antibiotics may have adverse effects on the reproductive system in the early life stages of different organisms like the freshwater flea Daphnia magna and the crustacean Artemia salina (Macrì et al., 1988; Wollenberger et al., 2000). In the study by Kim et al. (2007), sulfonamides (i.e. sulfamethoxazole, sulfachloropyridazine, sulfathiazole, sulfamethazine, sulfadimethoxine), and trimethoprim, were examined for their acute aquatic toxicity by employing a marine bacterium (V. fischeri), a freshwater flea (D. magna) and the Japanese medaka fish (Oryzias latipes). In this study, D. magna was in general the most susceptible in terms of effective/lethal concentrations-E/ $\mathrm{LC}_{50}$, among the test organisms.

Moreover, the extensive use of antibiotics has contributed to the development of antibiotic resistance genes and bacteria, reducing the therapeutic potential against human and animal pathogens (Kemper, 2008). The consequences are particularly worrying as bacteria in the aquatic environment can be continually exposed to antibiotic residues (Rosal et al., 2010). The biological treatment process creates an environment potentially suitable for resistance development and spreading, because bacteria are continuously exposed to 
environmentally relevant levels of antibiotics. However, it remains unclear where most of the resistant bacteria have been selected, and in particular if the low antibiotic concentrations that are present in natural environments or in human/animal body compartments during therapeutic use, are important for the selection and enrichment of resistant mutants (Gullberg et al., 2012). The extent to which human activities contribute to the development of resistant bacterial strains is still poorly understood (Auerbach et al., 2007). The number of studies, focusing exclusively on wastewater treatment systems regarding the removal of antibiotic resistance, is still however limited.

Gao et al. (2012) investigated the relationship between concentrations of tetracyclines and sulfonamides and the number of antibiotic resistance genes and antibiotic resistant bacteria in a conventional UWTP located in Michigan. Significant reductions (2-3 logs) of antibiotic resistance genes and antibiotic resistant bacteria were observed between raw influent and final effluent whereas no apparent decrease was observed in the concentrations of tetracycline resistance genes (tetO and tetW) and sulfonamide resistance gene (sulI) by chlorine disinfection. Moreover, Dodd (2012) provide a comprehensive overview on the significance of antibiotic resistant genes (ARG) and bacteria occurrence in environmental systems, and a discussion on the role that commonly used water and wastewater disinfection processes may play in minimizing ARG transport and dissemination.

Zhang et al. (2009) reported the impact of the wastewater treatment process on the prevalence of antibiotic resistance in Acinetobacter spp. in the wastewater and the possible spread of antibiotic resistance to receiving water bodies. It was found that the prevalence of antibiotic resistance was significantly higher in the downstream samples than in the upstream samples, with the higher values occurred for trimethoprim (97\%), followed by rifampin (74\%). Other studies have reported that the prevalence of resistant bacteria in sewage may significantly vary, depending on the plant (initial quality characteristics of sewage, type of treatment, plant operation, etc.), the target bacterial population, and the antimicrobial agent under study, as well as on the methods and the breakpoint values used to determine antimicrobial resistance (Guardabassi et al., 2002).

Another issue related to the use of reclaimed wastewater for irrigation is the plant uptake of antibiotics. The accumulation may or may not affect the growth and development of plants; however, the uptake into plants may represent an important exposure pathway of these compounds to humans and other biota (European Medicines Agency-EMEA). Migliore et al. (2003) determined the phytotoxicity of enrofloxacin on crop plants Cucumis sativus, Lactuca sativa, Phaseolus vulgaris and Raphanus sativus in a laboratory model. Between 50 and $5000 \mu \mathrm{g} \mathrm{L} \mathrm{L}^{-1}$, enrofloxacin induced hormetic effect in plants, with a dose-dependant stimulation or toxicity on the length of primary root, hypocotyl, cotyledons and the number/length of leaves. There are also new concerns that antibiotics decrease the biodegradation of leaf and other plant materials, which serves as the primary food source for aquatic life in rivers and streams (Richardson and Ternes, 2011).

The aim of the present paper is to introduce a critical review on the removal efficiency of various antibiotics in wastewater treatment during the application of different processes, namely biological processes, advanced treatment technologies and disinfection. An effort to include as many studies as possible was made in order to highlight important findings and present the knowledge currently available on the removal efficiency of antibiotics from wastewater through a variety of treatment processes.

\section{Fate of antibiotics in UWTPs}

The conventional wastewater treatment generally consists of a primary, secondary and sometimes a tertiary stage, with different biological and physicochemical processes available for each stage of the treatment. Primary treatment intends to reduce the solid content of the wastewater (oils and fats, grease, sand, grit and settleable solids). This step is performed entirely mechanically by means of filtration and sedimentation and is common at all UWTPs. However, the secondary treatment, which typically relies on a biological process to remove organic matter and/or nutrients with aerobic or anaerobic systems, can differ substantially. Several biological treatments are being used in modern municipal UWTPs, but the most common method is conventional activated sludge (CAS). Membrane bioreactors (MBR), moving bed biofilm reactor (MBBR), or fixed bed bioreactors (FBR) are less common. Activated sludge plants use dissolved oxygen to promote the growth of a biological floc that substantially removes the organic material and nitrogen at given conditions. In the final step, tertiary wastewater treatment processes can be applied to remove phosphorus by precipitation and particles on a filter (Batt et al., 2007). In some UWTPs the effluent is also disinfected before it is released into the environment, typically by chlorination or ultraviolet irradiation.

The effect of biological treatments, membrane filtration, activated carbon adsorption, advanced oxidation processes (AOPs), and disinfection on different classes of antibiotics has been widely investigated in the last years; several of these studies are presented in the subsequent paragraphs.

\subsection{Effect of biological treatment on antibiotics' removal}

Elimination and transformation of antibiotics during the biological treatment is the result of different processes. These processes can be biotic (biodegradation, mainly by bacteria and fungi) and non-biotic or abiotic (e.g. sorption, hydrolysis, photolysis).

The removal of antibiotics mainly depends on their sorption on the sewage sludge and their degradation or transformation during the treatment. Hydrolysis can play a role for some compounds, while photolysis is not very likely to occur due to the low exposure of the substances to light during the wastewater treatment.

Hydrophobic (or non-polar) antibiotic residues are expected to occur at higher concentration in primary and secondary sludge than hydrophilic ones because they have a greater affinity to solids and hence, concentrate in the organic-rich sewage sludge (Le-Minh et al., 2010). Antibiotics can also be removed from aqueous solutions onto solid 
particulates by ion exchange, complex formation with metal ions and polar hydrophilic interactions (Diaz-Cruz et al., 2003). Antibiotics that are sorbed to flocs, suspended solids and activated sludge, are removed from the aqueous phase by sedimentation and subsequent disposal of excess sludge. The affinity of antibiotics sorbed to sludge is most often represented by sludge sorption constants $K_{d}\left(\mathrm{~L} \mathrm{~kg}^{-1}\right)$. The higher $K_{d}$ values the higher sorption of the compounds to sludge. A review on $K_{d}$ values of several antibiotics is provided in Kovalova et al. (2012). It is important to note that the sludge is often used as fertilizer on agriculture fields, but in several European countries this is forbidden and the sludge is incinerated. Using sludge as fertilizer can therefore be considered as another input pathway for various antibiotics into the environment.

The tendency to accumulate in sludge solids can be assessed using the octanol-water partition coefficient ( $\left.\mathrm{K}_{\mathrm{OW}}\right)$. Rogers (1996) proposed the following guide to assess the sorption potential of organic contaminants: $\log \mathrm{K}_{\mathrm{ow}}<2.5$ : low sorption potential (e.g. tetracyclines, sulfonamides, aminoglycosides); $2.5<\log K_{\mathrm{ow}}<4.0$ (e.g. $\beta$-lactams, macrolides): medium sorption potential and $\log K_{\mathrm{OW}}>4.0$ (e.g. glycopeptides): high sorption potential. However, it should be emphasized that the prediction of the antibiotics sorption onto solids or sludge is mainly possible for non-polar compounds, while the prediction of the behavior of polar or charged compounds is often not correct. In some cases, the use of $\log K_{\text {Ow }}$ values lead to an underestimation of the sorption of e.g. fluoroquinolones (Golet et al., 2003) or tetracyclines (Kim et al., 2005) to sludge. For instance, ciprofloxacin (fluoroquinolone) has a $K_{\mathrm{OW}}$ value of 1.8 , but nevertheless sorbs onto sludge by $80 \%$, indicating that sorption is the main elimination process.

However, antibiotics are mostly hydrophilic and were designed to be biologically resistant; they are therefore expected to mainly remain in the aqueous phase of the wastewater.

The main operational factors that can influence the biological removal of antibiotic residues in wastewater treatment are biochemical oxygen demand $\left(\mathrm{BOD}_{5}\right)$, existence and size of anoxic and anaerobic compartments, suspended solids (SS) loading, hydraulic retention time (HRT), sludge retention time (SRT), food-microorganism ratio (F/M ratio), mixed liquorsuspended solids (MLSS), pH and temperature (Drewes, 2008; Kovalova et al., 2012).

The SRT is related to the growth rate of microorganisms. High SRTs allow the enrichment of slowly growing bacteria and therefore, provide greater diversity of enzymes, some of which are capable of degrading the antibiotic compounds (Jones et al., 2007; Le-Minh et al., 2010). High SRT can be reached with a membrane bioreactor (MBR), where the suspended activated sludge is retained in the reactor by utilizing a membrane for solid/liquid separation instead of a settling tank as used in CAS. Commonly, micro- or ultrafiltration membranes are used in MBRs, which do not retain the antibiotics on the filter. Some studies have been performed to investigate if higher SRTs enhance the elimination of antibiotics, which will be discussed in detail below (Joss et al., 2005; Göbel et al., 2007; Radjenovic et al., 2009b; Tadkaew et al., 2011; Kovalova et al., 2012).
The performance (expressed as \% removal) of some UWTPs applying biological treatment for removing antibiotics as reported in the literature is summarized in Table 1. The removal is highly variable for many substances (from nearly complete to very little). Frequently, however, operational details are not provided in the studies available in the literature on the fate and transport of antibiotic residues during wastewater treatment or have not been systematically investigated. This poses a major challenge for the comparison and discussion of results. Moreover, differences in reported efficiencies may, in some cases, be attributed to limitations of employed mass balance techniques (Le-Minh et al., 2010). For example, short-term variations of pharmaceuticals loads in influent can be significant (Göbel et al., 2005; Khan and Ongerth, 2005), thus consideration must be taken when comparing influent and effluent concentrations.

Antibiotics can be grouped by either their chemical structure or mechanism of action. The main groups of antibiotics and their potential removal during conventional wastewater treatment are discussed in the following sections.

\subsection{1. $\beta$-Lactams}

$\beta$-lactams are not very stable due to hydrolysis of the betalactam ring (Hirsch et al., 1999; Längin et al., 2009). $\beta$-lactams have been reported to be significantly reduced during biological treatment with removals higher than $90 \%$ (Watkinson et al., 2007, 2009). According to Li et al. (2009) the observed removals at an UWTP in Hong Kong were between 30.4 and $100 \%$. $\beta$-lactams were also eliminated significantly at both Shatin and Stanley UWTPs as described in the work of Li and Zhang (2011). Cha et al. (2006) investigated the fate of four $\beta$ lactams (ampicillin, cloxacillin, cephapirin, oxacillin) and the estimated removals were between 17 and 43\%. Ampicillin was removed by $82 \%$ in an activated sludge process (Li and Zhang, 2011). High removal of ampicillin ( $>94 \%$ ) was also achieved in MBR treatment (SRT 3-60 days, Xia et al., 2012). A significant removal (96\%) of cephalexin from $2000 \mathrm{ng} \mathrm{L}^{-1}$ to $78.2 \mathrm{ng} \mathrm{L}^{-1}$ has been reported to occur through conventional UWTP processes in Australia (Costanzo et al., 2005). Analysis of amoxicillin conducted by Zuccato et al. (2010) in UWTPs in Italy and Switzerland showed that it is efficiently removed by CAS $(100 \%)$. Similarly, Watkinson et al. (2009) showed that amoxicillin is quite susceptible to microbial degradation with removal higher than $99 \%$ and therefore it is not likely to remain in significant concentration after biological treatment systems. Cephalexin was removed by $53 \%$ at the Shatin UWTP, while it was removed by $91 \%$ at the Stanley UWTP (Li and Zhang, 2011). Cephalexin was also removed by $36-99.8 \%$ in four Taiwanese UWTPs combining biological treatment and disinfection process (UV or chlorination) (Lin et al., 2009a,b) and by $99.6 \%$ in an Australian UWTP using CAS (Watkinson et al., 2009). Therefore, cephalexin is relatively easily eliminated in UWTPs with biological processes, whereas cefotaxime, which was only detected in Shatin UWTP, was removed by only $43 \%$ (Li and Zhang, 2011).

\subsubsection{Macrolides}

Li and Zhang (2011) reported that roxithromycin was degraded by $40-46 \%$ during CAS. Slightly lower removal $(33 \%)$ was reported for one German UWTP (Ternes et al., 2007). In the 
Table 1 - Removal of antibiotics from wastewater effluents through biological treatment.

Antibiotic group

Initial concentration

Effluent concentration $\left(\mathrm{ng} \mathrm{L}^{-1}\right)$ / (ng L ${ }^{-1}$ ) (\% Removal efficiency)

Reference Antibiotic

\begin{tabular}{|c|c|c|}
\hline \multicolumn{3}{|l|}{$\beta$-Lactams } \\
\hline \multirow[t]{4}{*}{ Amoxicillin } & 280 & Primary/270 $\left(3.6 \%{ }^{*}\right)$ \\
\hline & & $\mathrm{CAS} / \mathrm{nd}\left(100 \%^{*}\right)$ \\
\hline & 18 & CAS/nd $\left(100 \%^{* *}\right)$ \\
\hline & 6940 & $50(99 \% *)$ \\
\hline \multirow[t]{9}{*}{ Ampicillin } & 17 & $13\left(23.5 \%{ }^{*}\right)$ \\
\hline & $n d-389.5$ & CAS/126.4 $\pm 6.6\left(67.5 \%{ }^{* *}\right)$ \\
\hline & & CAS + chlorination $/ n d$ \\
\hline & $(<34.4)$ & $\mathrm{CAS}_{\text {Shatin }}(n e)$ \\
\hline & $77.2-383$ & $\mathrm{CAS}_{\text {Stanley }}\left(82 \%{ }^{* *}\right)$ \\
\hline & & Disinfection $(91 \% * *)$ \\
\hline & & Final $(97 \% * *)$ \\
\hline & $5^{*} 10^{5}$ & MBR \\
\hline & & $(94.4,99.6,99.9,99.9 \% * *)_{[\mathrm{STR}}=3,10,30,60$ days $]$ \\
\hline \multirow[t]{12}{*}{ Cephalexin } & 2000 & $78.2\left(96 \%{ }^{*}\right)$ \\
\hline & 5600 & Primary/3900 (30\%*) \\
\hline & & CAS/nd $(100 \% *)$ \\
\hline & $670-2900$ & $240-1800(\sim 9-89 \% * *)$ \\
\hline & $1563-4367$ & $10-994(36-99.8 \% * *)$ \\
\hline & 64000 & $250\left(99.6 \%{ }^{*}\right)$ \\
\hline & $175.4-534.9$ & CAS/375.6 $\pm 19.7\left(30.4 \%^{* *}\right)$ \\
\hline & & CAS + chlorination $/ n d\left(100 \%{ }^{* *}\right)$ \\
\hline & 658-1718; & $\mathrm{CAS}_{\text {Shatin }}(53 \% * *)$ \\
\hline & $65.7-525$ & $\operatorname{CAS}_{\text {Stanley }}\left(91 \%^{* *}\right)$ \\
\hline & & Disinfection $(99 \% * *)$ \\
\hline & & Final $(100 \% * *)$ \\
\hline \multirow[t]{2}{*}{ Penicillin G } & 29 & $n a\left(<\mathrm{LOD}^{* *}\right)$ \\
\hline & 10 & $300(29 \% *)$ \\
\hline \multirow[t]{3}{*}{ Penicillin V } & 160 & Primary/10 (94\%*) \\
\hline & & CAS/20 $\left(87.5 \%{ }^{*}\right)$ \\
\hline & 13800 & $2000(86 \% *)$ \\
\hline \multirow[t]{4}{*}{ Cloxacillin } & 320 & Primary/nd $\left(100 \%{ }^{*}\right)$ \\
\hline & & CAS/nd $\left(100 \%{ }^{*}\right)$ \\
\hline & 13 & $9\left(31 \%^{*}\right)$ \\
\hline & 4600 & $700(85 \% *)$ \\
\hline \multirow[t]{3}{*}{ Cefaclor } & 980 & Primary/800 (18\%*) \\
\hline & & CAS/nd $(100 \% *)$ \\
\hline & 6150 & $1800\left(71 \%^{*}\right)$ \\
\hline \multirow[t]{5}{*}{ Cefotaxime } & $24-1100$ & $34\left(<\mathrm{LOD}^{* *}\right)$ \\
\hline & 38.4-93.0; & $\operatorname{CAS}_{\text {Shatin }}\left(\sim 43 \%{ }^{* *}\right)$ \\
\hline & nd & $\mathrm{CAS}_{\text {Stanley }}(n e)$ \\
\hline & & Disinfection (ne) \\
\hline & & Final (ne) \\
\hline Cephapirin & 18 & $15(17 \% *)$ \\
\hline Oxacillin & 14 & $8(43 \% *)$ \\
\hline \multicolumn{3}{|l|}{ Macrolides } \\
\hline \multirow[t]{15}{*}{ Roxithromycin } & 18 & Primary/9 (50\%*) \\
\hline & & $\mathrm{CAS} / 60\left(<0 \%{ }^{*}\right)$ \\
\hline & $10-40$ & Primary/10-50 $\left(3-9 \%{ }^{* *}\right)$ \\
\hline & & CAS $/ 10-30\left(-18\right.$ to $\left.38 \%^{* *}\right)$ \\
\hline & & $\operatorname{MBR}\left(38,60,57 \%{ }^{*}\right)_{[\text {SRT }} 16,33,60-80$ days] \\
\hline & & $\operatorname{FBR}(\sim 24 \% *)$ \\
\hline & $26-117$ & CAS/36-69 $\left(<0^{*}\right)$ \\
\hline & & $\begin{array}{l}\mathrm{MBR} /(n d, 31,42)_{[\mathrm{SRT}}=10,27,55 \text { days] } \\
\left(100,52,64 \%^{*}\right)\end{array}$ \\
\hline & 500 & $500(0 \% *)$ \\
\hline & $3.5-25.3$ & CAS $/ 14.2 \pm 1.1(43.9 \% * *)$ \\
\hline & & CAS + chlorination $/ 2.9 \pm 0.0\left(17.1 \%^{* *}\right)$ \\
\hline & $810 \pm 420$ & $540 \pm 70(33 \% * *)$ \\
\hline & $102 \pm 32 ; 164 \pm 31$ & CAS + chlorination $/ 36 \pm 21(65 \% *)$ \\
\hline & $75 \pm 14 ; 156 \pm 29$ & Oxidation ditch $+\mathrm{UV} / 278 \pm 46\left(<0 \%{ }^{*}\right)$ \\
\hline & & CAS $/ 35 \pm 8\left(53 \%{ }^{*}\right)$ \\
\hline
\end{tabular}

Watkinson et al., 2007

Zuccato et al., 2010

Watkinson et al., 2009

Cha et al., 2006

Li et al., 2009

Li and Zhang, 2011

Xia et al., 2012

Costanzo et al., 2005

Watkinson et al., 2007

Gulkowska et al., 2008

Lin et al., 2009

Watkinson et al., 2009

Li et al., 2009

Li and Zhang, 2011

Gulkowska et al., 2008

Watkinson et al., 2009

Watkinson et al., 2007

Watkinson et al., 2009

Watkinson et al., 2007

Cha et al., 2006

Watkinson et al., 2009

Watkinson et al., 2007

Watkinson et al., 2009 Gulkowska et al., 2008 Li and Zhang, 2011

Cha et al., 2006

Cha et al., 2006

Watkinson et al., 2007

Göbel et al., 2005;

Göbel et al., 2007

Clara et al., 2005

Watkinson et al., 2009

Li et al., 2009

Ternes et al., 2007

Xu et al., 2007 
Table 1 - (continued)

Antibiotic group Antibiotic

Initial concentration (ng L ${ }^{-1}$ )

50

35.6-135; 4.2-141

$\mathrm{Na}$

600

500-1000

$10^{4}$

$5^{*} 10^{4}$

Azithromycin

$\begin{array}{ll} & 139 \\ & 500-1000 \\ & 110-142 \\ & 55 \\ & 60 \\ & 1150 \pm 70 \\ \text { Clarithromycin } & 59-1433 \\ & 330-660 \\ & \\ & 319 \\ & 105.7-724.2 \\ 460 \pm 100 \\ \mathrm{Na} \\ 1500\end{array}$

Erythromycin
152

90-380

$4.5-53$

1150 (UWTP I);

$660_{\text {(UWTP II); }}$

$1680_{\text {(UWTP III) }}$

1500

2555

500-1000

$700-2720$

$71-141$

12

$380_{\text {(UWTP I); }}$;

$280_{\text {(UWTP II) }}$

$700_{\text {(UWTP III) }}$
Effluent concentration $\left(\mathrm{ng} \mathrm{L}^{-1}\right)$ / (\% Removal efficiency)
Reference

Chemically enhanced

+ Chlorination/37 $\pm 11\left(76 \%{ }^{*}\right)$

$\left(40,60,55 \%{ }^{*}\right)_{[\mathrm{STR}}=16,33,60-80$ days]

$\mathrm{CAS}_{\text {Shatin }}\left(46 \%{ }^{* *}\right)$

$\operatorname{CAS}_{\text {Stanley }}\left(40 \%^{* *}\right)$

Disinfection $\left(18 \%^{* *}\right)$

Final $\left(53 \%^{* *}\right)$

$<(5)-31$

MBR/RO

MBR $\left(89.5 \pm 7.7 \% * *{ }^{* *}[\right.$ [RT $>40$ days]

RO $\left(99.6 \pm 0.4 \%^{* *}\right)$

CAS-UF/RO

UF $\left(81.4 \pm 10.1 \%^{* *}\right)$

RO $(99.9 \pm 0.1 \% * *)$

$\operatorname{MBR}\left(>50 \%{ }^{* *}\right)_{[\mathrm{STR}}>100$ days]

$\left(77 \%^{* *}\right)_{\text {[SRT }}=44-72$ days]

$\operatorname{MBR}\left(57 \%^{* *}\right)$ [SRT $=15$ days]

$\operatorname{MBR}\left(81 \%^{* *}\right)$ [SRT $=30$ days]

$96\left(37 \%{ }^{*}\right)$

Primary $/ 80-320\left(10-33 \%^{* *}\right)$

CAS $/ 40-380\left(-26\right.$ to $\left.55 \%^{* *}\right)$

$\operatorname{MBR}\left(<0,5,25 \%{ }^{*}\right)_{\text {[SRT } 16,33,60-80 \text { days] }}$

FBR $\left(12.5 \%{ }^{*}\right)$

4-23 (11-57\%*)

Secondary

UWTP I/1600 $\left(<0^{*}\right)$

UWTP II/300 (55\%*)

UWTP III/530 (68\%*)

Outlet

UWTP I/180 (84\%*)

UWTP II/200 (70\%*)

UWTP III/30 (98\%*)

$\operatorname{MBR}\left(21 \%^{* *}\right)_{\text {[STR }}=30-50$ days]

$\operatorname{MBR}\left(>50 \%^{* *}\right)_{[\text {[TR }}>100$ days]

MBR-RO $\left(75 \%^{* *}\right)_{\text {[STR }}=45$ days]

Primary/nd $\left(100 \%{ }^{*}\right)$

CAS/20 (64\%*)

$3400\left(<0 \%{ }^{*}\right)$

$60 \pm 4\left(95 \%{ }^{*}\right)$

12-32 (99\%**)

Primary/160-440 (11-14\%**)

CAS/150-460 (-45 to $\left.20 \%{ }^{* *}\right)$

MBR $\left(54,40,90 \%{ }^{*}\right)_{[S R T} 16,33,60-80$ days]

$\operatorname{FBR}\left(\sim 10 \%{ }^{*}\right)$

CAS/117 $\left(13 \%{ }^{* *}\right)$

$(<\mathrm{LOQ})-610.6\left(16 \%{ }^{*}\right)$

$210 \pm 40\left(54 \%{ }^{* *}\right)$

$57-328$

MBR/RO

MBR $\left(91.4 \pm 5.4 \%^{* *}\right)_{[S R T}>40$ days]

RO $\left(99.2 \pm 0.8 \%{ }^{* *}\right)$

CAS-UF/RO

UF $\left(93.2 \pm 5.0 \%{ }^{* *}\right)$

RO $\left(99.2 \pm 0.8 \%^{* *}\right)$

$\operatorname{MBR}\left(50 \%{ }^{* *}\right)_{\text {[STR }}=30-50$ days]

$\operatorname{MBR}\left(>50 \% *{ }^{* *}\right)_{[\mathrm{STR}}>100$ days]

MBR-RO $\left(87 \%^{* *}\right)_{\text {[STR }}=45$ days]

$145-290\left(79 \% *{ }^{*}\right)$

$\mathrm{CAS} / 52(0 \% * *)$

Secondary

UWTP I/200 (47\%*)

UWTP II/250 (11\%*)

UWTP III/420 (40\%*)
Joss et al., 2005

Li and Zhang, 2011

McArdell et al., 2003

Sahar et al., 2010

Abegglen et al., 2009

Reif et al., 2008

Tambosi et al., 2010

Gros et al., 2006

Göbel et al., 2005;

Göbel et al., 2007

Loganathan et al., 2009

Fatta et al., 2010

Kovalova et al., 2012

Abegglen et al., 2009

Dolar et al., 2012

Watkinson et al., 2007

Watkinson et al., 2009

Yang et al., 2004

Lin et al., 2009

Göbel et al., 2005;

Göbel et al., 2007

Zuccato et al., 2010

Spongberg and Witter, 2008

Ternes et al., 2007

McArdell et al., 2003

Sahar et al., 2010

Kovalova et al., 2012

Abegglen et al., 2009

Dolar et al., 2012

Roberts and Thomas, 2006

Zuccato et al., 2010

Fatta et al., 2010 
Table 1 - (continued)

Antibiotic group

Initial concentration

Effluent concentration $\left(\mathrm{ng} \mathrm{L}^{-1}\right) /$

Reference Antibiotic $\left(\mathrm{ng} \mathrm{L}^{-1}\right)$ (\% Removal efficiency)

\begin{tabular}{|c|c|c|c|}
\hline & & $\begin{array}{l}\text { Outlet } \\
\text { UWTP I/30 }\left(92 \%^{*}\right) \\
\text { UWTP II/400 }\left(<0^{*}\right) \\
\text { UWTP III/<LOD }\left(100 \%^{*}\right)\end{array}$ & \\
\hline & $830 \pm 270$ & $620 \pm 440(25 \% * *)$ & Ternes et al., 2007 \\
\hline & $751 \pm 109$ & CAS + chlorination $/ 430 \pm 73\left(43 \%{ }^{*}\right)$ & Xu et al., 2007 \\
\hline & $1978 \pm 233$ & Oxidation ditch $+\mathrm{UV} / 2054 \pm 386\left(<0^{*}\right)$ & \\
\hline & $253 \pm 22$ & $\mathrm{CAS} / 216 \pm 34\left(15 \%^{*}\right)$ & \\
\hline & $469 \pm 38$ & $\begin{array}{l}\text { Chemically enhanced } \\
+ \text { chlorination/259 } \pm 20\left(45 \%^{*}\right)\end{array}$ & \\
\hline & 1000 & $\mathrm{MBR} / \mathrm{RO}$ & Sahar et al., 2010 \\
\hline & & $\operatorname{MBR}\left(90.4 \pm 8.2 \%^{* *}\right)_{[\mathrm{SRT}>40}$ days] & \\
\hline & & RO $\left(99.3 \pm 0.7 \%^{* *}\right)$ & \\
\hline & & CAS-UF/RO & \\
\hline & & $\mathrm{UF}\left(72.2 \pm 6.8 \%^{* *}\right)$ & \\
\hline & & $\mathrm{RO}\left(99.3 \pm 0.7 \%^{* *}\right)$ & \\
\hline & $32-80$ & MBR-RO $\left(80 \%{ }^{* *}\right)_{[S T R=45}$ days] & Dolar et al., 2012 \\
\hline & $10^{4}$ & $\left(91 \%^{* *}\right)_{[\mathrm{SRT}=44-72 \text { days] }}$ & Reif et al., 2008 \\
\hline Erythromycin- $\mathrm{H}_{2} \mathrm{O}$ & $470-810$ & $510-850\left(-12\right.$ to $\left.19 \%{ }^{* *}\right)$ & Gulkowska et al., 2008. \\
\hline & $226-1537$ & $361-811(56 \% * *)$ & Lin et al., 2009 \\
\hline & $(<50)-1300$ & $(<50)-300(43.8-100 \% * *)$ & Karthikeyan and Meyer, 2006 \\
\hline & 60-190 & Primary/40-190 ( -8 to $\left.4 \%^{* *}\right)$ & Göbel et al., 2005; \\
\hline & & $\mathrm{CAS} / 50-140\left(-22\right.$ to $\left.7 \%^{* *}\right)$ & Göbel et al., 2007 \\
\hline & & 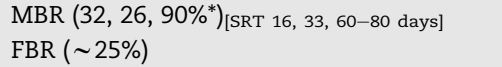 & \\
\hline & $16.7-51.3$ & CAS/96.3 $\pm 6.0\left(55.6 \%^{* *}\right)$ & Li et al., 2009 \\
\hline & & CAS + chlorination/37.9 $\pm 0.6\left(26.1 \%^{* *}\right)$ & \\
\hline & $200 \pm 10$ & $80 \pm 5(60 \% *)$ & Yang et al., 2004 \\
\hline & $258-409 ; 169-374$ & $\operatorname{CAS}_{\text {Shatin }}(15 \% * *)$ & Li and Zhang, 2011 \\
\hline & & $\mathrm{CAS}_{\text {Stanley }}\left(26 \%^{* *}\right)$ & \\
\hline & & Disinfection $(24 \% * *)$ & \\
\hline & & Final $\left(43 \%{ }^{* *}\right)$ & \\
\hline & na & $<(20)-199$ & McArdell et al., 2003 \\
\hline & 820 & CAS $(35.4 \pm 50.5 \% * *)$ & Radjenovic et al., 2009b \\
\hline & & MBR HF-UF $\left(25.2 \pm 108.9 \%^{* *}\right)_{[S R T}>60$ days] & \\
\hline & & MBR FS-MF $\left(43.0 \pm 51.5 \%^{* *}\right)_{[S R T}>60$ days] & \\
\hline & 188 & $\operatorname{MBR}\left(<60 \% * *{ }_{[S T R}=30-50\right.$ days] & Kovalova et al., 2012 \\
\hline & $242-6755$ & Trickling filter beds/292-2841 $\left(0 \%{ }^{* *}\right)$ & Kasprzyk-Hordern et al., 2009 \\
\hline & $144-10025$ & $\mathrm{CAS} / 23-2772(50 \% * *)$ & \\
\hline Spiramycin & 603 & CAS/454 $(25 \% * *)$ & Zuccato et al., 2010 \\
\hline Sulfonamides & & & \\
\hline Sulfamethoxazole & 500 & Primary/570 (<0\%*) & Watkinson et al., 2007 \\
\hline & & CAS/200 $(60 \% *)$ & \\
\hline & $179-1760$ & $47-964\left(26-88 \%{ }^{* *}\right)$ & Lin et al., 2009 \\
\hline & 1090 & $210(\sim 81 \% * *)$ & Yang et al., 2005 \\
\hline & 450 & $(<30)\left(>93 \%{ }^{*}\right)$ & Choi et al., 2007 \\
\hline & 590 & $390\left(34 \%{ }^{*}\right)$ & Gros et al., 2006 \\
\hline & 390 & $310\left(20 \%{ }^{* *}\right)$ & Brown et al., 2006 \\
\hline & $n d-145$ & CAS/18-50 & Clara et al., 2005 \\
\hline & & $\begin{array}{l}\left.\mathrm{MBR} /(56, n d, n d)_{[\mathrm{SRT}}=10,27,55 \text { days }\right] \\
\left(61,100,100 \%{ }^{*}\right)\end{array}$ & \\
\hline & $5450_{(\text {GZ-UWTP1) }}$ & GZ-UWTP $_{1}$ & Peng et al., 2006 \\
\hline & $7910_{(\mathrm{GZ}-\mathrm{UWTP2})}$ & Primary/9460 $\left(<0^{*}\right)$ & \\
\hline & & Secondary/nq & \\
\hline & & Tertiary/nd & \\
\hline & & GZ-UWTP 2 & \\
\hline & & Primary/nq & \\
\hline & & Secondary/nq & \\
\hline & & Tertiary/nd & \\
\hline & $(<80)-674$ & $(<80)-304(42 \% * *)$ & Lindberg et al., 2005 \\
\hline & 20 & $70\left(<0^{* *}\right)$ & Bendz et al., 2005 \\
\hline
\end{tabular}


Table 1 - (continued)

Antibiotic group Antibiotic

\begin{tabular}{|c|c|c|c|}
\hline & $(<50)-1250$ & $(<50)-370(17.8-100 \% * *)$ & Karthikeyan and Meyer, 2006 \\
\hline & $250-640$ & $250(67 \% * *)$ & Carballa et al., 2004 \\
\hline & $230-570$ & Primary/90-640 (-21 to $\left.(-5) \%^{* *}\right)$ & Göbel et al., 2005; \\
\hline & & Secondary/130-840 (-138 to $\left.60 \%{ }^{* *}\right)$ & Göbel et al., 2007 \\
\hline & & $\operatorname{MBR}\left(38,40,37 \%{ }^{*}\right)_{[S R T} 16,33,60-80$ days] & \\
\hline & & $\operatorname{FBR}\left(\sim 62.5 \%^{*}\right)$ & \\
\hline & 246 & CAS/46 $(81 \% * *)$ & Zuccato et al., 2010 \\
\hline & 3000 & $200(93 \% *)$ & Watkinson et al., 2009 \\
\hline & $146.5-355.5$ & $\mathrm{CAS} / 46.6 \pm 2.6\left(68.2 \%^{* *}\right)$ & Li et al., 2009 \\
\hline & & CAS + chlorination $/ 15.3 \pm 0.3(95.7 \% * *)$ & \\
\hline & $500-10000$ & $(65-96 \% * *)$ & Yu et al., 2009 \\
\hline & na & UWTP I & Renew and Huang, 2004 \\
\hline & & Secondary $/(<60)-640$ & \\
\hline & & Chlorination $/(<50)-70$ & \\
\hline & & UWTP II & \\
\hline & & Secondary/100-1600 & \\
\hline & & $\mathrm{UV} / 330-2140$ & \\
\hline & $13-155$ & $4-39(69-75 \% *)$ & Pailler et al., 2009 \\
\hline & na & $\begin{array}{l}\text { Amherst (Primary/2800 } \pm 300 ; C A S / 1200 \pm 3 \\
\text { Nitrification/700 } \pm 40 ; \text { Tertiary } / 630 \pm 60 ; \\
\text { Final/680 } \pm 30 \text { ) } \\
\text { East Aurora (Primary } / 880 \pm 80 ; \\
\text { Secondary } / 200 \pm 3 ; \\
\text { Tertiary } / 190 \pm 5 ; \text { Final } / 220 \pm 20 \text { ) } \\
\text { Holland (Primary } / 750 \pm 40 ; \\
\text { Secondary } / 480 \pm 30 ; \\
\text { Tertiary } / 450 \pm 20 ; \text { Final } / 500 \pm 60) \\
\text { Lackawana (Primary } / 720 \pm 60 ; \\
\text { Secondary } / 460 \pm 40 ; \text { Final } / 380 \pm 30 \text { ) }\end{array}$ & Batt et al., 2007 \\
\hline & $820 \pm 230$ & $620 \pm 90\left(24 \%^{* *}\right)$ & Ternes et al., 2007 \\
\hline & $16 \pm 5 ; 118 \pm 17$ & CAS + chlorination/16 $\pm 7(0 \%)$ & Xu et al., 2007 \\
\hline & $10 \pm 3 ; 25 \pm 7$ & Oxidation ditch + UV/78 $\pm 13\left(34 \%^{*}\right)$ & \\
\hline & & $\mathrm{CAS} / 12 \pm 3\left(<0^{*}\right)$ & \\
\hline & & Chemically enhanced & \\
\hline & & + chlorination $/ 9 \pm 4\left(64 \%^{*}\right)$ & \\
\hline & $52.0-127 ; 163-230$ & CAS $_{\text {Shatin }}(90 \% * *)$ & Li and Zhang, 2011 \\
\hline & & $\mathrm{CAS}_{\text {Stanley }}\left(62 \%^{* *}\right)$ & \\
\hline & & Disinfection $(27 \% * *)$ & \\
\hline & & Final $\left(73 \%{ }^{* *}\right)$ & \\
\hline & 93 & $\operatorname{CAS}\left(73.8 \pm 12.7 \%^{* *}\right)$ & Radjenovic et al., 2009b \\
\hline & & MBR HF-UF $\left(78.3 \pm 13.9 \%^{* *}\right)_{[S R T}>60$ days] & \\
\hline & & MBR FS-MF $\left(80.8 \pm 12.2 \%^{* *}\right)[$ SRT $>60$ days] & \\
\hline & 500 & $\mathrm{MBR} / \mathrm{RO}$ & Sahar et al., 2010 \\
\hline & & $\operatorname{MBR}\left(69.6 \pm 7.3 \%^{*}\right)_{[\mathrm{SRT}}>40$ days] & \\
\hline & & $\mathrm{RO}\left(97.6 \pm 2.4 \%^{*}\right)$ & \\
\hline & & CAS-UF/RO & \\
\hline & & UF $\left(60.3 \pm 21.7 \%^{*}\right)$ & \\
\hline & & $\mathrm{RO}\left(97.6 \pm 2.4 \%^{*}\right)$ & \\
\hline & 3476 & $(7 \% * *)$ & Kovalova et al., 2012 \\
\hline & $500-1000$ & $\operatorname{MBR}(75-90 \% * *)_{[S T R}>100$ days] & Abegglen et al., 2009 \\
\hline & $5^{*} 10^{5}$ & MBR & Xia et al., 2012 \\
\hline & & $\left(88.5,96.9,99.3,99.5 \%^{* *}\right)_{[\mathrm{STR}}=3,10,30,60$ days $]$ & \\
\hline & $20-268$ & MBR-RO $\left(69 \%^{* *}\right)_{[\mathrm{STR}}=45$ days] & Dolar et al., 2012 \\
\hline & $10^{4}$ & $\operatorname{MBR}\left(52 \%{ }^{* *}\right)_{[\mathrm{SRT}}=44-72$ days] & Reif et al., 2008 \\
\hline & $5 * 10^{4}$ & $\operatorname{MBR}\left(55 \%^{* *}\right)_{[\mathrm{SRT}}=15$ days] & Tambosi et al., 2010 \\
\hline & & $\operatorname{MBR}\left(86 \%^{* *}\right)[\mathrm{SRT}=30$ days] & \\
\hline & $<3-150 ; 20-274$ & Trickling filter beds $/<3-23(0 \% * *)$ & Kasprzyk-Hordern et al., 2009 \\
\hline & & $\mathrm{CAS} / 4-44\left(70 \%^{* *}\right)$ & \\
\hline $\mathrm{N}^{4}$-Acetylsulfamethoxazole & $850-1600$ & Primary/570-1200 (9-21\%**) & Göbel et al., 2005; \\
\hline & & $\mathrm{CAS} /<20-150\left(81-96 \%{ }^{* *}\right)$ & Göbel et al., 2007 \\
\hline & & 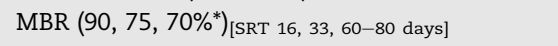 & \\
\hline & 1000 & $\left(92,75,68 \%^{*}\right)_{[\mathrm{STR}}=16,33,60-80$ days $]$ & Joss et al., 2005 \\
\hline & 2394 & $\operatorname{MBR}\left(81 \%^{* *}\right)_{[\mathrm{STR}}=30-50$ days $]$ & Kovalova et al., 2012 \\
\hline
\end{tabular}

\section{Effluent concentration (ng L $\left.\mathrm{L}^{-1}\right) /$ \\ Reference} (\% Removal efficiency) 
Table 1 - (continued)

Antibiotic group

Initial concentration (ng L ${ }^{-1}$ )

\begin{tabular}{|c|c|c|}
\hline \multirow[t]{16}{*}{ Sulfamethazine } & 150 & $(<30)\left(>80 \%{ }^{*}\right)$ \\
\hline & 4010 & $(<30)(>99 \% *)$ \\
\hline & $110-210$ & $(<50)(100 \% * *)$ \\
\hline & $2000-10000$ & $(32-85 \% * *)$ \\
\hline & $(<\mathrm{LOQ})-26.9$ & $<$ LOQ $(100 \% *)$ \\
\hline & $3.2-54.7 ; 17.8$ & $\operatorname{CAS}_{\text {Shatin }}(100 \% * *)$ \\
\hline & & $\operatorname{CAS}_{\text {Stanley }}(100 \% * *)$ \\
\hline & & Disinfection (ne) \\
\hline & & Final $\left(100 \%^{* *}\right)$ \\
\hline & 3 & $\mathrm{MBR} / \mathrm{RO}$ \\
\hline & & $\operatorname{MBR}\left(90.2 \pm 9.8 \%^{*}\right)_{[\mathrm{SRT}}>40$ days] \\
\hline & & $\mathrm{RO}\left(93.5 \pm 6.5 \%^{*}\right)$ \\
\hline & & CAS-UF/RO \\
\hline & & UF $(73.5 \pm 16.2 \% *)$ \\
\hline & & $\mathrm{RO}\left(93.5 \pm 6.5 \%^{*}\right)$ \\
\hline & $500-1000$ & $\operatorname{MBR}\left(75-90 \%{ }^{* *}\right)_{[S T R}>100$ days] \\
\hline \multirow[t]{19}{*}{ Sulfadiazine } & $5100_{(\mathrm{GZ}-\mathrm{UWTP} 1)}$ & GZ-UWTP $_{1}$ \\
\hline & $5150_{(\text {GZ-UWTP2) }}$ & Primary/4180 (19\%*) \\
\hline & & Secondary/nd \\
\hline & & Tertiary /nd \\
\hline & & GZ-UWTP 2 \\
\hline & & Primary/nd \\
\hline & & Secondary/nd \\
\hline & & Tertiary/nd \\
\hline & nd-73.0 & $\mathrm{CAS} / 16.2 \pm 0.0(72.8 \% * *)$ \\
\hline & & $\mathrm{CAS}+$ chlorination $/ n d$ \\
\hline & $72 \pm 22$ & CAS + chlorination $/ 36 \pm 13\left(50 \%^{*}\right)$ \\
\hline & $36.0-55.4$ & $\operatorname{CAS}_{\text {Shatin }}\left(100 \%^{* *}\right)$ \\
\hline & $4.4-530$ & $\operatorname{CAS}_{\text {Stanley }}\left(87 \%{ }^{* *}\right)$ \\
\hline & & Disinfection $\left(4 \%^{* *}\right)$ \\
\hline & & Final $\left(88 \%{ }^{* *}\right)$ \\
\hline & 1896 & $\operatorname{MBR}\left(-23 \%^{* *}\right)_{[\mathrm{STR}}=30-50$ days] \\
\hline & $500-1000$ & $\operatorname{MBR}\left(75-90 \%{ }^{* *}\right)_{[S T R}>100$ days] \\
\hline & $5 * 10^{5}$ & MBR \\
\hline & & $\left(93.8,97.5,99.6,99.7 \%^{* *}\right)_{[\mathrm{STR}}=3,10,30,60$ days $]$ \\
\hline \multirow[t]{5}{*}{ Sulfathiazole } & 40 & Primary/nd $\left(100 \%{ }^{*}\right)$ \\
\hline & & $\mathrm{CAS} /$ nd $\left(100 \%{ }^{*}\right)$ \\
\hline & 10570 & $180\left(98 \%{ }^{*}\right)$ \\
\hline & 300 & $600\left(<0 \%{ }^{*}\right)$ \\
\hline & $(1.0)-2.0$ & $(<1.0)\left(100 \%{ }^{*}\right)$ \\
\hline Sulfamerazine & 1530 & $(<30)\left(>98 \% *^{*}\right)$ \\
\hline Sulfachloropyridazine & 1560 & $60\left(>93 \%{ }^{*}\right)$ \\
\hline \multirow[t]{5}{*}{ Sulfadimethoxine } & 70 & $(<30)(>57 \% *)$ \\
\hline & 460 & $(<30)\left(>93 \% *^{*}\right)$ \\
\hline & $2000-10000$ & $\left(61-96 \%{ }^{* *}\right)$ \\
\hline & $(<(\mathrm{LOQ})-2.6)$ & $(<\mathrm{LOQ})-1.9\left(27 \%{ }^{*}\right)$ \\
\hline & $(1.0)-26$ & $(1.0)-9.0\left(65 \%^{*}\right)$ \\
\hline \multirow[t]{5}{*}{ Sulfapyridine } & $60-150$ & Primary ( -29 to $\left.20 \%{ }^{* *}\right)$ \\
\hline & & CAS $\left(-107\right.$ to $\left.72 \%^{* *}\right)$ \\
\hline & & $\operatorname{MBR}\left(60,48,55 \%^{*}\right)_{[\operatorname{SRT}} 16,33,60-80$ days] \\
\hline & & FBR $\left(72 \%{ }^{*}\right)$ \\
\hline & $500-1000$ & $\operatorname{MBR}(75-90 \% * *){ }_{[\text {STR }}>100$ days] \\
\hline \multirow[t]{3}{*}{ Sulfasalazine } & 60 & Primary/15 $\left(75 \%^{*}\right)$ \\
\hline & & CAS/nd $(100 \% *)$ \\
\hline & 100 & $150(<0 \% *)$ \\
\hline Sulfamonomethoxine & 3110 & $(<30)(>99 \% *)$ \\
\hline Sulfisoxazole & $(<\mathrm{LOQ})-22.1)$ & $(<\mathrm{LOQ})-11.9\left(46 \%{ }^{*}\right)$ \\
\hline \multirow[t]{2}{*}{ Sulfadimidine } & $25 \pm 12 ; 696 \pm 212$ & CAS + chlorination/12 $\pm 6\left(52 \%^{*}\right)$ \\
\hline & & Oxidation ditch + UV/346 $\pm 54\left(50 \%{ }^{*}\right)$ \\
\hline \multicolumn{3}{|l|}{ Quinolones } \\
\hline Norfloxacin & na & 210 \\
\hline
\end{tabular}

Effluent concentration (ng L $\left.{ }^{-1}\right) /$

Reference

Yang et al., 2005

Choi et al., 2007

Karthikeyan and Meyer, 2006 Yu et al., 2009

Spongberg and Witter, 2008

Li and Zhang., 2011

Sahar et al., 2010

Abegglen et al., 2009

Peng et al., 2006

Li et al., 2009

Xu et al., 2007

Li and Zhang, 2011

Kovalova et al., 2012

Abegglen et al., 2009

Xia et al., 2012

Watkinson et al., 2007

Choi et al., 2007

Watkinson et al., 2009

Pailler et al., 2009

Choi et al., 2007

Choi et al., 2007

Yang et al., 2005

Choi et al., 2007

Yu et al., 2009

Spongberg and Witter, 2008

Pailler et al., 2009

Göbel et al., 2005;

Göbel et al., 2007

Abegglen et al., 2009

Watkinson et al., 2007

Watkinson et al., 2009

Choi et al., 2007

Spongberg and Witter, 2008

$\mathrm{Xu}$ et al., 2007

Costanzo et al., 2005 
Table 1 - (continued)

Antibiotic group Antibiotic

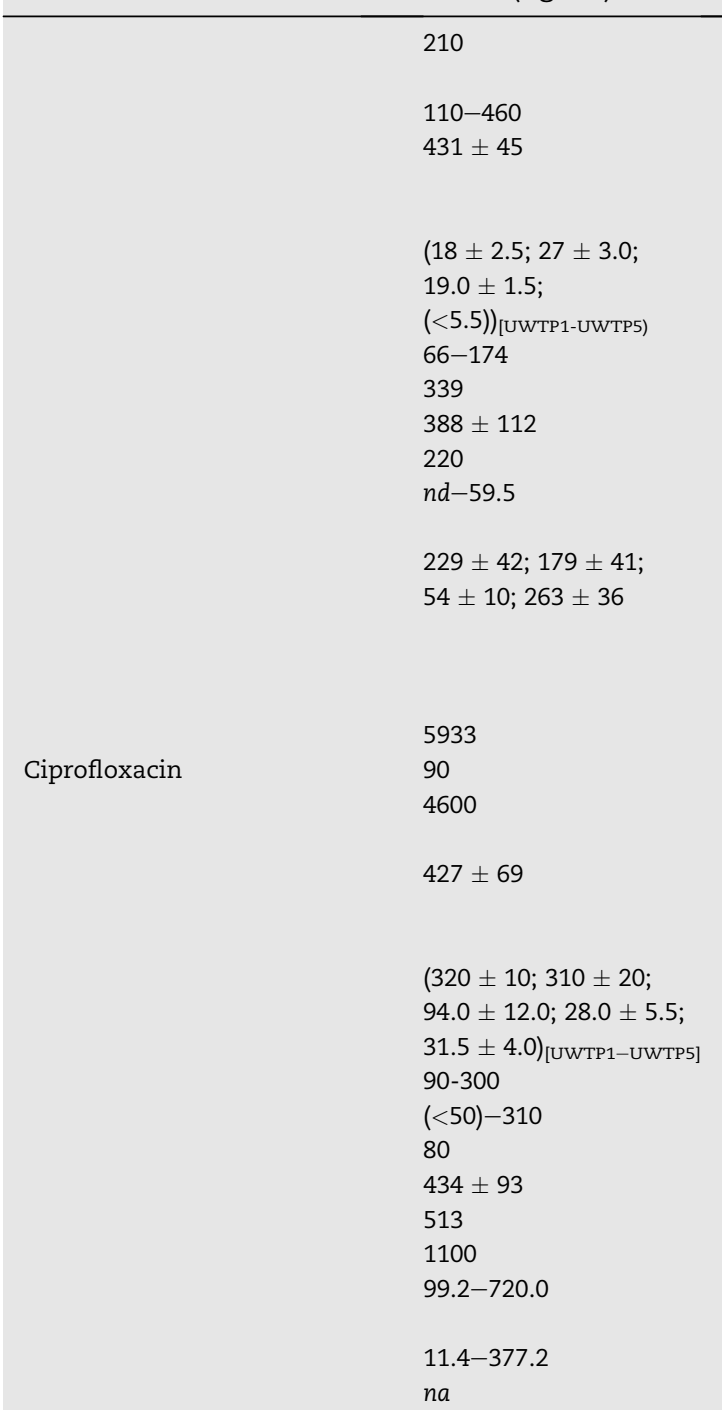

na

1674.20

555-1033; 98.6-235

31980
Effluent concentration $\left(\mathrm{ng} \mathrm{L}^{-1}\right)$ / (\% Removal efficiency)
Primary/145 (31\%*)

CAS/15 (93\%*)

$85-320$ ( -20 to $\left.78 \%{ }^{* *}\right)$

Primary/383 $\pm 61\left(11 \%{ }^{*}\right)$

Secondary/69 $\pm 15\left(84 \%{ }^{*}\right)$

Tertiary/51 \pm 7 (88\%*)

$(>70 \% * *)$

$(<7)-37\left(87 \%{ }^{* *}\right)$

$85\left(75 \%{ }^{*}\right)$

$57 \pm 12\left(82 \pm 3 \%{ }^{* *}\right)$

$250\left(<0 \%{ }^{*}\right)$

CAS/13.9 $\pm 0.5\left(76.6 \%^{* *}\right)$

CAS + chlorination/nd

CAS + chlorination/44 \pm 19 (81\%*)

Oxidation ditch + UV/62 $\pm 13(65 \% *)$

CAS $/ 27 \pm 6\left(50 \%{ }^{*}\right)$

Chemically enhanced

+ chlorination/85 $\pm 12\left(68 \%{ }^{*}\right)$

$\operatorname{MBR}\left(47 \%^{* *}\right)_{\text {[STR }=30-50 \text { days] }}$

$138.2(<0 \% *)$

Primary/6900 (<0\%*)

CAS/742 (84\%*)

Primary/331 \pm 53 (22\%*)

Secondary/95 $\pm 15\left(78 \%{ }^{*}\right)$

Tertiary/71 \pm 11 (83\%*)

$(>90 \% * *)$

7-60 (87\%**)

$(<50)-60(22.2-100 \% * *)$

$27\left(66 \%{ }^{*}\right)$

$72 \pm 14\left(82 \pm 3 \%{ }^{* *}\right)$

CAS/147 (71\%**)

nd $(100 \% *)$

CAS/73.3 $\pm 3.0\left(89.8 \%{ }^{* *}\right)$

CAS + chlorination/7.6 $\pm 0.7\left(92.3 \%{ }^{* *}\right)$

88-109.9 (71\%*)

UWTP I

Secondary $/(<30)-100$

Chlorination $/(<20)$

UWTP II

Secondary/80-370

$\mathrm{UV} /(<20)$

Amherst (Primary/1100 $\pm 100 ; \mathrm{CAS} / 450 \pm 1$;

Nitrification/450 \pm 4 ; Tertiary/450 \pm 3 ;

Final/540 \pm 5 )

East Aurora (Primary/610 \pm 30 ;

Secondary $/ 290 \pm 30$

Tertiary/220 \pm 9; Final/220 \pm 7 )

Holland (Primary/1400 \pm 300 ;

Secondary/590 \pm 10 ;

Tertiary/450 $\pm 60 ;$ Final/340 \pm 60 )

Lackawana (Primary/920 \pm 50 ;

Secondary/460 $\pm 10 ;$ Final/270 \pm 20 )

$626.50\left(63 \%{ }^{*}\right)$

CAS $_{\text {Shatin }}\left(18 \%{ }^{* *}\right)$

CAS $_{\text {Stanley }}\left(55 \% \%^{* *}\right)$

Disinfection (18\%**)

Final $\left(66 \%{ }^{* *}\right)$

$\operatorname{MBR}\left(51 \%^{* *}\right)_{[\text {STR }}=30-50$ days]
Reference

Watkinson et al., 2007

Gulkowska et al., 2008

Golet et al., 2003

Zorita et al., 2009

Lindberg et al., 2005

Xiao et al., 2008

Golet et al., 2002

Watkinson et al., 2009

Li et al., 2009

Xu et al., 2007

Kovalova et al., 2012

Costanzo et al., 2005

Watkinson et al., 2007

Golet et al., 2003

Zorita et al., 2009

Lindberg et al., 2005

Karthikeyan and Meyer, 2006

Xiao et al., 2008

Golet et al., 2002

Zuccato et al., 2010

Watkinson et al., 2009

Li et al., 2009

Spongberg and Witter, 2008 Renew and Huang, 2004

Batt et al., 2007

Castiglioni et al., 2008

Li and Zhang, 2011

Kovalova et al., 2012 
Table 1 - (continued)

Antibiotic group Antibiotic

Initial concentration $\left(\mathrm{ng} \mathrm{L}^{-1}\right)$

Effluent concentration (ng L ${ }^{-1}$ )/ (\% Removal efficiency)

\begin{tabular}{|c|c|c|}
\hline \multirow[t]{3}{*}{ Enrofloxacin } & 100 & Primary/20 (80\%*) \\
\hline & & CAS/5 (95\%*) \\
\hline & 40 & $50(<0 \% *)$ \\
\hline \multirow[t]{44}{*}{ Ofloxacin } & $115-1274$ & $53-991(2-88 \% * *)$ \\
\hline & 470 & $110(77 \% * *)$ \\
\hline & $\begin{array}{l}(22.5 \pm 2.5 ; 30.0 \pm 3.0 \\
19.5 \pm 3.0 ; 9.0 \pm 1.5 \\
10.0 \pm 1.0) \text { [UWTP1-UWTP5] }\end{array}$ & $\left(56 \%^{* *}\right)$ \\
\hline & $5560_{(\mathrm{GZ}-\mathrm{UWTP} 1)}$ & GZ-UWTP $_{1}$ \\
\hline & $3520_{\text {(GZ-UWTP2) }}$ & Primary/5700 (<0*) \\
\hline & & Secondary/860 (85\%*) \\
\hline & & Tertiary/740 (87\%*) \\
\hline & & GZ-UWTP 2 \\
\hline & & Primary/nq \\
\hline & & Secondary/nd (100\%*) \\
\hline & & Tertiary/nd (100\%*) \\
\hline & $7-287$ & $7-52\left(86 \%{ }^{* *}\right)$ \\
\hline & 1208 & $503\left(58 \%{ }^{*}\right)$ \\
\hline & 463 & CAS/235 $(49 \% * *)$ \\
\hline & $104.4-335.9$ & CAS/556.4 $\pm 28.7(-65.6 \% * *)$ \\
\hline & & CAS + chlorination/2.1 $\pm 0.3\left(98.0 \%^{* *}\right)$ \\
\hline & na & UWTP I \\
\hline & & Secondary/(<30)-350 \\
\hline & & Chlorination/ $(<20)-50$ \\
\hline & & UWTP II \\
\hline & & Secondary/140-260 \\
\hline & & $\mathrm{UV} / 100-210$ \\
\hline & $122620_{\text {(UWTP I) }}$ & Secondary \\
\hline & $34740_{(\text {UWTP II) }}$ & UWTP I/3020 (87\%*) \\
\hline & 59380 (UWTP III) & UWTP II/5930 (83\%*) \\
\hline & & UWTP III/3330 (94\%*) \\
\hline & & Outlet \\
\hline & & UWTP I/1290 (94\%*) \\
\hline & & UWTP II/4820 (86\%*) \\
\hline & & UWTP III/1900 (97\%*) \\
\hline & 539.80 & $183.10\left(66 \%{ }^{*}\right)$ \\
\hline & $137 \pm 58 ; 359 \pm 52$ & CAS + chlorination/41 $\pm 8(70 \% *)$ \\
\hline & $80 \pm 12 ; 368 \pm 23$ & Oxidation ditch $+\mathrm{UV} / 137 \pm 28\left(62 \%{ }^{*}\right)$ \\
\hline & & CAS/48 $\pm 7(40 \% *)$ \\
\hline & & Chemically enhanced \\
\hline & & + chlorination/165 $\pm 15\left(55 \%{ }^{*}\right)$ \\
\hline & $478-1042 ; 188-327$ & $\mathrm{CAS}_{\text {Shatin }}\left(26 \%{ }^{* *}\right)$ \\
\hline & & CAS $_{\text {Stanley }}(59 \% * *)$ \\
\hline & & Disinfection $\left(39 \%{ }^{* *}\right)$ \\
\hline & & Final $(74 \% * *)$ \\
\hline & 10500 & CAS $\left(75.8 \pm 13.8 \%{ }^{* *}\right)$ \\
\hline & & MBR HF-UF $\left(91.3 \pm 10.8 \%^{* *}\right)_{[S R T}>60$ days \\
\hline & & MBR FS-MF $\left(95.2 \pm 2.8 \%{ }^{* *}\right)_{[S R T}>60$ days] \\
\hline & $n d-2900$ & MBR-RO $(0 \% * *)_{[S T R=45 \text { days] }}$ \\
\hline \multirow[t]{4}{*}{ Nalidixic acid } & 200 & Primary/ nd (100\%*) \\
\hline & & CAS/1 (100\%*) \\
\hline & $26-372$ & $40-200(37-46 \% * *)$ \\
\hline & 200 & $450\left(<0 \%{ }^{*}\right)$ \\
\hline Pipemidic acid & 54 & $12(78 \% *)$ \\
\hline Flerofloxacin & 28 & $5.8(79 \% *)$ \\
\hline Lomefloxacin & 98 & $17(83 \% *)$ \\
\hline Gatifloxacin & 111 & $56(50 \% *)$ \\
\hline \multirow{4}{*}{$\begin{array}{l}\text { Moxifloxacin } \\
\text { Trimethoprim }\end{array}$} & 44 & $17(61 \% *)$ \\
\hline & 930 & Primary/480 (48\%*) \\
\hline & & CAS/30 (97\%*) \\
\hline & $120-320$ & $120-230\left(\sim-17\right.$ to $\left.62 \%^{* *}\right)$ \\
\hline
\end{tabular}

Reference

Watkinson et al., 2007

Watkinson et al., 2009

Lin et al., 2009

Brown et al., 2006

Zorita et al., 2009

Peng et al., 2006

Lindberg et al., 2005

Xiao et al., 2008

Zuccato et al., 2010

Li et al., 2009

Renew and Huang, 2004

Fatta et al., 2010

Castiglioni et al., 2008

$\mathrm{Xu}$ et al., 2007

Li and Zhang, 2011

Radjenovic et al., 2009b

Dolar et al., 2012

Watkinson et al., 2007

Lin et al., 2009

Watkinson et al., 2009

Xiao et al., 2008

Xiao et al., 2008

Xiao et al., 2008

Xiao et al., 2008

Xiao et al., 2008

Watkinson et al., 2007

Gulkowska et al., 2008

(continued on next page) 
Table 1 - (continued)

Antibiotic group Antibiotic
Initial concentration $\left(\mathrm{ng} \mathrm{L}^{-1}\right)$
Effluent concentration (ng L ${ }^{-1}$ )/ (\% Removal efficiency)
Reference

\begin{tabular}{|c|c|c|}
\hline $259-949$ & $203-415\left(\sim 22-56 \%^{* *}\right)$ & Lin et al., 2009 \\
\hline 1172 & $290\left(75 \%{ }^{*}\right)$ & Gros et al., 2006 \\
\hline 590 & $180(69 \% * *)$ & Brown et al., 2006 \\
\hline $99-1300$ & $66-1340(3 \% * *)$ & Lindberg et al., 2005 \\
\hline $140-1100$ & $(<50)-550(50-100 \% * *)$ & Karthikeyan and Meyer, 2006 \\
\hline 80 & $40(49 \% * *)$ & Bendz et al., 2005 \\
\hline $213-300$ & $218-322\left(3 \%^{* *}\right)$ & Roberts and Thomas., 2006 \\
\hline \multirow[t]{4}{*}{$210-440$} & Primary/80-340 ( -13 to $\left.31 \%^{* *}\right)$ & Göbel et al., 2005; \\
\hline & $\mathrm{CAS} / 80-400\left(-40\right.$ to $\left.20 \%^{* *}\right)$ & Göbel et al., 2007 \\
\hline & $\operatorname{MBR}\left(28,33,87 \%^{*}\right)_{[\text {SRT } 16,33,60-80 \text { days] }}$ & \\
\hline & FBR $\left(\sim 20 \%^{*}\right)$ & \\
\hline \multirow[t]{2}{*}{400} & Primary $\left(\sim 20 \%{ }^{* *}\right)$ & Sui et al., 2010 \\
\hline & Secondary $(76 \pm 24 \% * *)$ & \\
\hline 4300 & $250(94 \% *)$ & Watkinson et al., 2009 \\
\hline \multirow[t]{2}{*}{$128.7-161.2$} & CAS/ $66.2 \pm 0.7\left(48.6 \%^{* *}\right)$ & Li et al., 2009 \\
\hline & CAS + chlorination $/ 10.8 \pm 1.1\left(93.3 \%{ }^{* *}\right)$ & \\
\hline 1000 & $\left(74 \%{ }^{* *}\right)$ & Yu et al., 2009 \\
\hline \multirow[t]{6}{*}{ na } & UWTP I & Renew and Huang, 2004 \\
\hline & Secondary/30-1210 & \\
\hline & Chlorination/ $(<40)$ & \\
\hline & UWTP II & \\
\hline & Secondary/270-1220 & \\
\hline & $\mathrm{UV} /(<40)-1760$ & \\
\hline \multirow[t]{12}{*}{ na } & Amherst (Primary/7900 \pm 400 & Batt et al., 2007 \\
\hline & $\mathrm{CAS} / 7600 \pm 500 ;$ Nitrification $/ 2500 \pm 300$ & \\
\hline & Tertiary $/ 2600 \pm 200$ & \\
\hline & Final $/ 2400 \pm 200)$ & \\
\hline & East Aurora (Primary/7000 \pm 1000 & \\
\hline & Secondary $/ 300 \pm 30$ & \\
\hline & Tertiary/270 $\pm 20 ;$ Final/210 \pm 9 ) & \\
\hline & Holland (Primary/2300 \pm 500 & \\
\hline & Secondary $/ 580 \pm 20$ & \\
\hline & Tertiary $/ 570 \pm 10 ;$ Final $/ 540 \pm 50$ ) & \\
\hline & Lackawana (Primary/2100 \pm 400 & \\
\hline & Secondary $/ 590 \pm 3 ;$ Final $/ 360 \pm 40$ ) & \\
\hline $50_{\text {(UWTP I) }} ; 140_{\text {(UWTP II); }}$; & Secondary & Fatta et al., 2010 \\
\hline \multirow[t]{7}{*}{350 (UWTP III) } & UWTP I/<LOD (100\%*) & \\
\hline & UWTP II/90 (36\%*) & \\
\hline & UWTP III/60 (83\%*) & \\
\hline & Outlet & \\
\hline & UWTP I/<LOD (100\%*) & \\
\hline & UWTP II/<LOD (100\%*) & \\
\hline & UWTP III/<LOD (100\%*) & \\
\hline $1100 \pm 260$ & $340 \pm 80\left(69 \%^{* *}\right)$ & Ternes et al., 2007 \\
\hline 100-154; & $\operatorname{CAS}_{\text {Shatin }}\left(13 \%{ }^{* *}\right)$ & Li and Zhang., 2011 \\
\hline \multirow[t]{3}{*}{$136-172$} & $\mathrm{CAS}_{\text {Stanley }}\left(42 \%^{* *}\right)$ & \\
\hline & Disinfection $\left(40 \%{ }^{* *}\right)$ & \\
\hline & Final $\left(65 \%{ }^{* *}\right)$ & \\
\hline \multirow[t]{3}{*}{204} & $\operatorname{CAS}\left(40.4 \pm 25.4 \%^{* *}\right)$ & Radjenovic et al., 2009b \\
\hline & MBR HF-UF $\left(47.5 \pm 22.5 \%^{* *}\right)_{[\text {SRT }}>60$ days] & \\
\hline & MBR FS-MF $\left(66.7 \pm 20.6 \%^{* *}\right)_{[\text {SRT }}>60$ days] & \\
\hline \multirow[t]{6}{*}{30} & $\mathrm{MBR} / \mathrm{RO}$ & Sahar et al., 2010 \\
\hline & $\operatorname{MBR}\left(96 \pm 4 \%{ }^{*}\right)_{[\mathrm{SRT}}>40$ days] & \\
\hline & $\mathrm{RO}\left(97.2 \pm 2.8 \%^{*}\right)$ & \\
\hline & CAS-UF/RO & \\
\hline & UF $\left(66.4 \pm 20.5 \%{ }^{*}\right)$ & \\
\hline & $\mathrm{RO}\left(93.2 \pm 6.8 \%^{*}\right)$ & \\
\hline 930 & $\operatorname{MBR}\left(96 \%{ }^{* *}\right)_{[\mathrm{STR}}=30-50$ days] & Kovalova et al., 2012 \\
\hline $10^{4}$ & $\operatorname{MBR}\left(36 \%{ }^{* *}\right)_{[\mathrm{SRT}}=44-72$ days] & Reif et al., 2008 \\
\hline \multirow[t]{2}{*}{$5^{*} 10^{4}$} & $\operatorname{MBR}\left(55 \%^{* *}\right)_{[\mathrm{SRT}}=15$ days] & Tambosi et al., 2010 \\
\hline & $\operatorname{MBR}\left(86 \%^{* *}\right)_{[\mathrm{SRT}}=30$ days] & \\
\hline 464-6769; & Trickling filter beds/625-3052 (40\%**) & Kasprzyk-Hordern et al., 2009 \\
\hline $1514-4673$ & CAS/385-1218 $\left(70 \%{ }^{* *}\right)$ & \\
\hline
\end{tabular}


Table 1 - (continued)

Antibiotic group

Initial concentration $\left(\mathrm{ng} \mathrm{L}^{-1}\right)$
Effluent concentration ( $\mathrm{ng} \mathrm{L}^{-1}$ )/ (\% Removal efficiency)

\begin{tabular}{|c|c|c|}
\hline \multicolumn{3}{|l|}{ Tetracyclines } \\
\hline \multirow[t]{29}{*}{ Tetracycline } & 35 & Primary/nd (100\%*) \\
\hline & & CAS/20 $\left(43 \%{ }^{*}\right)$ \\
\hline & $96-1300$ & $180-620(-88$ to $73 \% * *)$ \\
\hline & $46-234$ & $16-38\left(66-90 \%{ }^{* *}\right)$ \\
\hline & 200 & $(<30)\left(>\sim 85 \%{ }^{*}\right)$ \\
\hline & 110 & $(<30)\left(>73 \%{ }^{*}\right)$ \\
\hline & $240-790$ & $(<50)-160(67.9-100 \% * *)$ \\
\hline & 100 & $20\left(80 \%{ }^{*}\right)$ \\
\hline & $134.5-270.8$ & CAS/89.4 $\pm 4.2\left(67.0 \%{ }^{* *}\right)$ \\
\hline & & CAS + chlorination $/$ nd $\left(100 \%{ }^{* *}\right)$ \\
\hline & $29.3-38.9$ & $(<\mathrm{LOQ})-34.4\left(12 \%^{*}\right)$ \\
\hline & $(1.0)-85$ & $(1.0)-24\left(72 \%{ }^{*}\right)$ \\
\hline & na & Amherst (Primary/1100 \pm 100 \\
\hline & & $\mathrm{CAS} / 410 \pm 20 ;$ Nitrification $/ 170 \pm 10$ \\
\hline & & Tertiary/170 $\pm 2 ;$ Final/160 \pm 1$)$ \\
\hline & & East Aurora (Primary $/ 320 \pm 30$ \\
\hline & & Secondary/75 $\pm 3 ;$ Tertiary $/ 61 \pm 9$ \\
\hline & & Final/ $61 \pm 3)$ \\
\hline & & Holland (Primary/580 \pm 20 \\
\hline & & Secondary $/ 240 \pm 20$ \\
\hline & & Tertiary/220 $\pm 40 ;$ Final $/ 210 \pm 2$ ) \\
\hline & & Lackawana (Primary/430 \pm 200 \\
\hline & & Secondary $/ 240 \pm 20 ;$ Final $/ 290 \pm 30)$ \\
\hline & 221-353; & $\operatorname{CAS}_{\text {Shatin }}\left(24 \%^{* *}\right)$ \\
\hline & $59.8-110$ & $\operatorname{CAS}_{\text {Stanley }}(36 \% * *)$ \\
\hline & & Disinfection $\left(13 \%{ }^{* *}\right)$ \\
\hline & & Final $\left(39 \%{ }^{* *}\right)$ \\
\hline & $5^{*} 10^{5}$ & MBR \\
\hline & & $\left(83.6,89.7,92.6,93.6 \%^{* *}\right)_{[\mathrm{STR}=3,10,30,60 \text { days }]}$ \\
\hline \multirow[t]{9}{*}{ Chlortetracycline } & 270 & $60(\sim 78 \% * *)$ \\
\hline & 970 & $40(>96 \% *)$ \\
\hline & 200 & $250\left(<0 \%{ }^{*}\right)$ \\
\hline & $155 ; 178$ & $\operatorname{CAS}_{\text {Shatin }}\left(85 \% \%^{* *}\right)$ \\
\hline & & $\mathrm{CAS}_{\text {Stanley }}\left(82 \%{ }^{* *}\right)$ \\
\hline & & Disinfection $\left(6 \%{ }^{* *}\right)$ \\
\hline & & Final $\left(83 \%{ }^{* *}\right)$ \\
\hline & $5^{*} 10^{5}$ & MBR \\
\hline & & $(82.9,84.4,81.5,77.6 \%)_{[\mathrm{STR}}=3,10,30,60$ days $]$ \\
\hline \multirow[t]{6}{*}{ Doxycycline } & 65 & Primary/40 $\left(78 \%{ }^{*}\right)$ \\
\hline & & CAS/20 (69\%*) \\
\hline & 210 & $70(\sim 67 \% * *)$ \\
\hline & 220 & $30(86 \% *)$ \\
\hline & $(<64)-2480$ & $(<64)-915(\sim 70 \% * *)$ \\
\hline & 650 & $150(77 \% *)$ \\
\hline \multirow[t]{6}{*}{ Oxytetracycline } & 240 & $(<30)(>88 \% *)$ \\
\hline & 350 & $70(80 \% *)$ \\
\hline & $(1.0)-7.0$ & $(1.0)-5.0(29 \% *)$ \\
\hline & $53.5-107 ;$ nd & $\operatorname{CAS}_{\text {Shatin }}\left(44 \%{ }^{* *}\right)$ \\
\hline & $5^{*} 10^{5}$ & MBR \\
\hline & & $\left(79.7,84.4,87.9,88.6 \%^{* *}\right)_{[\mathrm{STR}}=3,10,30,60$ days $]$ \\
\hline Minocycline & 380 & $(<30)\left(>92 \%{ }^{*}\right)$ \\
\hline Democlocycline & 270 & $30(89 \% *)$ \\
\hline Meclocycline-Sulfosalicylate & 500 & $180\left(64 \%{ }^{*}\right)$ \\
\hline \multicolumn{3}{|l|}{ Lincosamides } \\
\hline \multirow[t]{5}{*}{ Lincomycin } & 80 & Primary/70 (12.5\%*) \\
\hline & & $\mathrm{CAS} / 50\left(37.5 \%{ }^{*}\right)$ \\
\hline & 9.7 & CAS/6.1 $\left(37 \%^{* *}\right)$ \\
\hline & 500 & $300\left(40 \%{ }^{*}\right)$ \\
\hline & 3.9 & $3.70(5 \% *)$ \\
\hline \multirow[t]{3}{*}{ Clindamycin } & 5 & Primary/5 (0\%*) \\
\hline & & $\mathrm{CAS} / 5\left(0 \%{ }^{*}\right)$ \\
\hline & 60 & $70(<0 \% *)$ \\
\hline
\end{tabular}

Watkinson et al., 2007

Gulkowska et al., 2008

Lin et al., 2009

Yang et al., 2005

Choi et al., 2007

Karthikeyan and Meyer, 2006

Watkinson et al., 2009

Li et al., 2009

Spongberg and Witter, 2008

Pailler et al., 2009

Batt et al., 2007

Li and Zhang, 2011

Xia et al., 2012

Yang et al., 2005

Choi et al., 2007

Watkinson et al., 2009

Li and Zhang, 2011

Xia et al., 2012

Watkinson et al., 2007

Yang et al., 2005

Choi et al., 2007

Lindberg et al., 2005

Watkinson et al., 2009

Choi et al., 2007

Watkinson et al., 2009

Pailler et al., 2009

Li and Zhang, 2011

Xia et al., 2012

Choi et al., 2007

Choi et al., 2007

Choi et al., 2007

Watkinson et al., 2007

Zuccato et al., 2010

Watkinson et al., 2009

Castiglioni et al., 2008

Watkinson et al., 2007

Watkinson et al., 2009 
Table 1 - (continued)

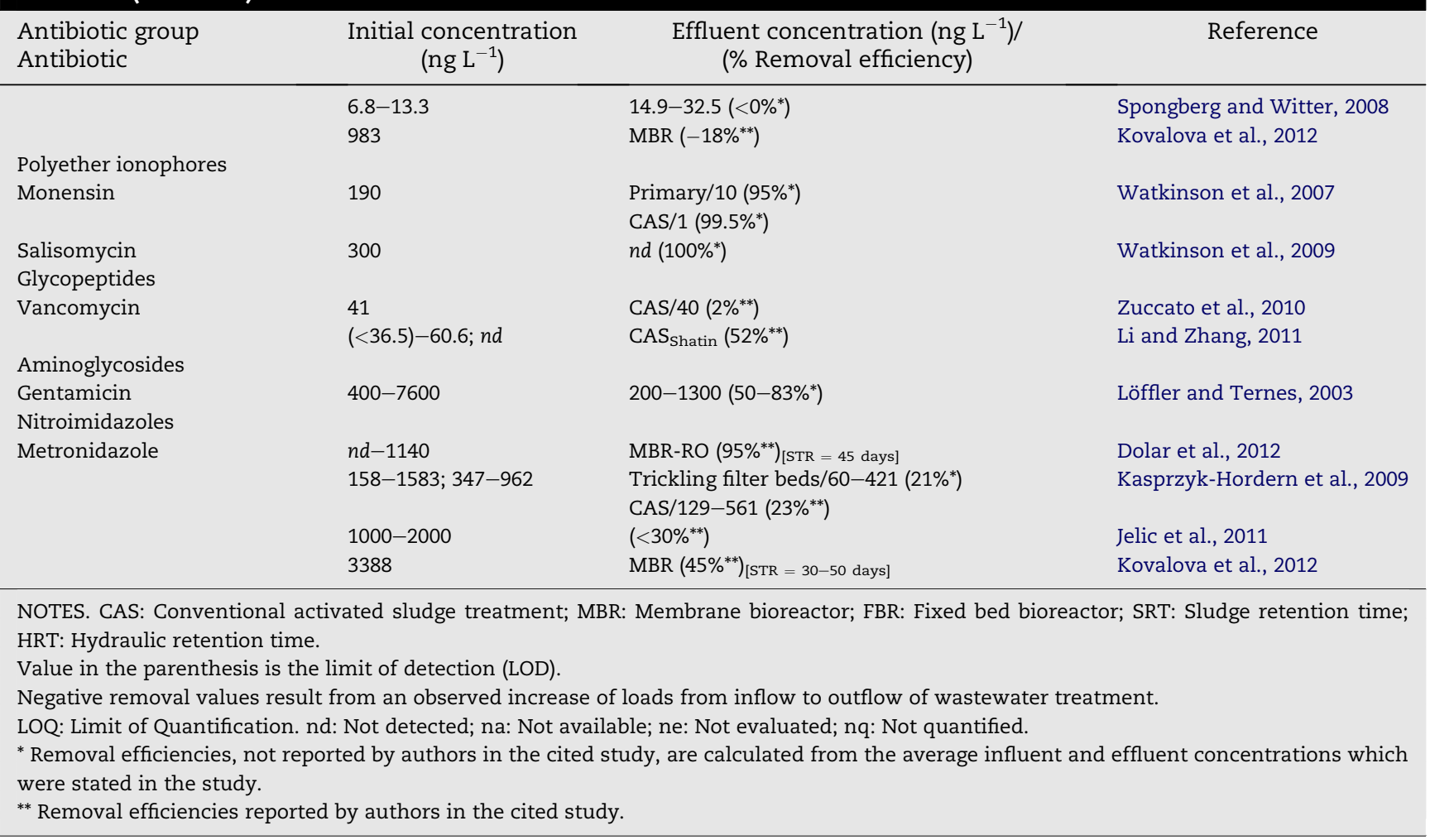

studies of Göbel et al. (2007) and Joss et al. (2005), roxithromycin was removed at two UWTPs in Switzerland by $38 \%$ during secondary treatment and by $38-57 \%$ during MBR treatment (SRT $=16,33,60-80$ days). Moreover, roxithromycin removal was reported to be higher than $53 \%$ for four UWTPs in south China (Xu et al., 2007). Clara et al. (2005) reported a removal range for roxithromycin of $52-100 \%$ during MBR treatment (SRT $=10-55$ days).

Erythromycin is frequently detected as its main human metabolite, the dehydrated product with an apparent loss of one molecule of water, erythromycin- $\mathrm{H}_{2} \mathrm{O}$. Erythromycin- $\mathrm{H}_{2} \mathrm{O}$ was degraded by $15 \%$ and $26 \%$ in activated sludge processes at Shatin and Stanley UWTP, respectively (Li and Zhang, 2011), and up to $10 \%$ in two Swiss UWTPs (Göbel et al., 2007). Higher removals were reported in other studies, that is, $56 \%$ in four Taiwanese UWTPs (Lin et al., 2009a,b) and 43.8-100\% in an UWTP in USA (Karthikeyan and Meyer, 2006) by secondary wastewater treatment processes both employing activated sludge.

For clarithromycin highly variable elimination rates are reported, from $\leq 20 \%$ (Göbel et al., 2007; Spongberg and Witter, 2008) up to $80 \%$ (Dolar et al., 2012; Lin et al., 2009a,b). For clarithromycin and erythromycin- $\mathrm{H}_{2} \mathrm{O}$ an influence of sludge age was observed with enhanced eliminations at higher SRTs (26-40\% at SRT $=33$ days, $90 \%$ at SRT $=60-80$ days in Göbel et al., 2007). Reif et al. (2008) also found high removals of roxithromycin and erythromycin (77\% and 91\%, respectively) in an MBR with SRT of 44-72 days.

Macrolides may be sorbed to biomass via cation exchange processes due to the fact that under typical wastewater conditions $(\mathrm{pH}=7-8)$, many are positively charged through the protonation of the basic dimethylamino group $\left(p K_{a}=7.1-9.2\right)$ while the surface of activated sludge is predominantly negatively charged (Le-Minh et al., 2010). Analysis of sludge, however, showed that sorption of macrolides is of minor importance for the elimination in conventional UWTPs with $K_{d}$ of below $400 \mathrm{~L} \mathrm{~kg}^{-1}$ (Göbel et al., 2005; Kovalova et al., 2012). Abegglen et al. (2009) observed a slightly higher affinity of MBR sludge to macrolides than conventional activated sludge ( $K_{d}=1400 \mathrm{~L} \mathrm{~kg}^{-1}$ for azithromycin).

\subsubsection{Sulfonamides}

The concentrations of these antibiotics in UWTP influents and effluents vary significantly, depending on consumption patterns and the types of wastewater treatment processes employed. For example, sulfamethoxazole has been reported at concentrations as high as 5450-7910 $\mathrm{ng} \mathrm{L}^{-1}$ in sewage influent in China and was completely removed during the treatment (Peng et al., 2006). In a Taiwanese UWTP, sulfamethoxazole was detected in influent at concentration range of 500-10,000 ng L $\mathrm{L}^{-1}$ and the removal was $65-96 \%$ after the biological treatment (Yu et al., 2009). Sulfamethoxazole has been reported to be removed up to $81 \%$ (initial concentration $1090 \mathrm{ng} \mathrm{L}^{-1}$ ) (Yang et al., 2005), 69-75\% (initial concentration in the range 13-155 $\mathrm{ng} \mathrm{L}^{-1}$ ) (Pailler et al., 2009), 68.2-95.7\% (initial concentration in the range $146-355 \mathrm{ng} \mathrm{L}^{-1}$ ) (Li et al., 2009) and 93\% (initial concentration in the range $3000 \mathrm{ng} \mathrm{L}^{-1}$ ) (Watkinson et al., 2009). However, in other studies lower removal rates of 20-24\% were reported (Brown et al., 2006; Ternes et al., 2007).

At this point it is worth mentioning that, there is only little knowledge on the environmental fate of humans' metabolites of antibiotics, which are excreted from the human body, often in considerable amounts and can be found predominantly in 
the environment (Hollender et al., 2008). Humans' metabolites are often omitted when analyzing antibiotics; a notable exception is the sulfamethoxazole's acetylated metabolite. $\mathrm{N}_{4}$-acetylsulfamethoxazole usually accounts for more than $50 \%$ of an administered dose in human excretion and can occur in UWTP influents at concentrations of 2.5-3.5 times higher than concentrations of the parent compound (Göbel et al., 2007). Significant removal efficiencies (81-96\% and 68-92\%, respectively) of $\mathrm{N}_{4}$-acetylsulfamethoxazole during secondary treatment were reported by Göbel et al. (2007) and Joss et al. (2005). $\mathrm{N}_{4}$-acetylsulfamethoxazole can also deconjugate into sulfamethoxazole during wastewater treatment (Göbel et al., 2007), leading to an underestimation of removal efficiency for sulfamethoxazole if this metabolite is not considered. This might be a reason for the highly varying observed elimination rates.

Higher removal rates were observed for sulfadiazine during activated sludge process at Shatin $(72.8 \%, 100 \%)$ and Stanley (87\%) UWTPs (Li et al., 2009; Li and Zhang, 2011). However, the removal rate for sulfadiazine was only $50 \%$ in a Chinese UWTP (Xu et al., 2007).

Sulfamethazine was removed to concentrations below detection in the study of Li and Zhang (2011), Karthikeyan and Meyer (2006), Choi et al. (2007) and Yang et al. (2005), achieving removal rates higher than $80 \%$. Yu et al. (2009) reported a removal of $32-85 \%$ in a UWTP in Colorado. Many other sulfonamides were eliminated during conventional processes with removal efficiencies varying from $<0$ to $100 \%$, but sorption to sludge was found to be negligible for sulfonamides (Yang et al., 2005; Choi et al., 2007; Göbel et al., 2007; Watkinson et al., 2007, 2009; Spongberg and Witter, 2008; Abegglen et al., 2009; Pailler et al., 2009; Tambosi et al., 2010).

The variation of sulfonamides removal may possibly be explained not only by the deconjugation of metabolites, but also by the differences in UWTP operating conditions such as HRT and the presence of an anaerobic compartment. Higher SRT, though, was not found to increase the elimination of sulfamethoxazole and sulfapyridine (Göbel et al., 2007; Radjenovic et al., 2009b).

\subsubsection{Trimethoprim}

The presence of trimethoprim can generally be correlated to that of sulfamethoxazole since the two drugs are often administered in combination (Göbel et al., 2005). The removal of trimethoprim has been reported as $13 \%$ and $42 \%$ by Li and Zhang (2011). The removal of this compound was found to fluctuate within the same levels in various UWTPs in USA (50-100\%), in Germany (69\%) and in Taiwan (74\%) (Brown et al., 2006; Karthikeyan and Meyer, 2006; Ternes et al., 2007; Yu et al., 2009). Higher removals were obtained in five UWTPs in Australia yielding 94\% (Watkinson et al., 2009) and 93.3\% (Li et al., 2009). In contrast, the removal of trimethoprim was negligible as reported in the studies of Lindberg et al. (2005) and Roberts and Thomas (2006).

Some studies have indicated that nitrifying microorganisms appear to be capable of degrading trimethoprim. This suggests an important role for aerobic conditions for the biotransformation of trimethoprim (Perez et al., 2005; Batt et al., 2006). Moreover, trimethoprim elimination was found to be increased at higher SRTs (Göbel et al., 2007; Radjenovic et al., 2009b; Tambosi et al., 2010; Kovalova et al., 2012).

\subsubsection{Quinolones}

Removal efficiencies of quinolones during wastewater treatment in Sweden were reported to be $87 \%$ for norfloxacin and ciprofloxacin and $86 \%$ for ofloxacin (Lindberg et al., 2005). A later study reported the removal of ciprofloxacin (>90\%), ofloxacin (56\%), and norfloxacin (>70\%) during activated sludge treatment followed by chemical coagulation/flocculation (Zorita et al., 2009). Sorption to sewage sludge has been suggested by Golet et al. (2003) as the primary removal mechanism for fluoroquinolones (ciprofloxacin and norfloxacin) during secondary wastewater treatment, resulting in the removal of $78-84 \%$ of the aforementioned fluoroquinolones from the aqueous phase. High removals of ofloxacin were achieved in UWTPs in Cyprus (>83\%) (Fatta-Kassinos et al., 2010) and in China (100\%) (Peng et al., 2006). Removal of ciprofloxacin in an MBR treating hospital wastewater (SRT $=30-50$ days) was only 51\% (Kovalova et al., 2012). This relatively low removal might have been caused by the lower sludge production in MBR than in conventional activated sludge, leading to lower sorption.

\subsubsection{Tetracyclines}

Tetracycline is one of the most frequently detected antibiotics in wastewater (Watkinson et al., 2007). According to the study of Yang et al. (2005) tetracycline was removed by $85 \%$ in an UWTP in Colorado. Li and Zhang (2011) reported removals of 24-36\% at two plants while higher removals (67.9-100\%) were reported by Karthikeyan and Meyer (2006) and four Taiwanese UWTPs (66-90\%) by Lin et al. (2009a,b)

The removal rates for chlortetracycline as reported by $\mathrm{Li}$ and Zhang (2011) were in the range of $82 \%$ and $85 \%$. Furthermore, for chlortetracycline and doxycycline, after secondary treatment and chlorination, the removal efficiencies were reported to be $78 \%$ and $67 \%$, respectively (Yang et al., 2005). Choi et al. (2007) reported even higher removal values for minocycline and democlocycline (92 and $89 \%$, respectively). High removal was also achieved for tetracyclines in MBR treatment (SRT $=3-60$ days, Xia et al., 2012).

Tetracyclines have complexing properties and can easily bind to calcium and similar ions, thus forming stable complexes, which can bind to suspended matter or sewage sludge (Drewes, 2008). Kim et al. (2005) found no evidence of tetracycline biodegradation during the biodegradability test, but sorption was found to be the principal removal mechanism in activated sludge. These properties might explain why tetracyclines are detected in many cases in low concentration levels $\left(\mathrm{ng} \mathrm{\textrm {L } ^ { - 1 }}\right.$ ) in treated secondary effluents.

\subsubsection{Other antibiotic groups}

Several studies reported the occurrence of lincosamides antibiotics such as lincomycin and clindamycin in wastewater influents and effluents with maximum removal efficiencies of 67\% (Zuccato et al., 2010; Kovalova et al., 2012). Clindamycin may be transformed back from the main human metabolite 
clindamycin sulfoxide in the denitrification process, resulting in increased concentration (Kovalova et al., 2012). A study by Watkinson et al. (2009) showed that removals of polyether ionophores (monensin and salinomycin) in wastewater were up to $95 \%$. Metronidazole, an imidazole antibiotic, was removed up to $23 \%$ during CAS (Kasprzyk-Hordern et al., 2009; Jelic et al., 2011) and $45 \%$ in an MBR treating hospital wastewater (SRT $=30-50$ days, Kovalova et al., 2012). Metronidazole is rapidly transformed into 1-(2-hydroxyethyl)-2-hydroxymethyl5-nitroimidazole (Mahugo-Santana et al., 2010). Limited information on the behavior of polyether ionophores through UWTP processes is available, due to the less likely occurrence of these antibiotics in urban wastewater except where there is runoff from agricultural lands into sewers. Glycopeptides such as vancomycin was analyzed by Li and Zhang (2011) and the removal after the activated sludge process was found to be as high as $52 \%$. The aminoglycoside gentamicin was found in hospital wastewater, although is a compound that is adsorbed very strongly (Loffler and Ternes, 2003).

In summary, biological treatment cannot completely remove antibiotics in wastewater treatment. Accordingly, alternative treatment processes are considered as necessary in order to provide further elimination of these compounds from wastewater effluents and to better manage environmental and human exposure to these contaminants.

In the following sections, other techniques including membrane filtration, activated carbon adsorption and advanced oxidation processes (AOPs) are discussed. The removal of antibiotics by these processes is depicted in Table 2 along with other relevant and important information. The upgrading of UWTPs and the application of such technologies is regarded as a possible optimization of the biological treatment with regard to antibiotics' removal.

\subsection{Membrane processes}

Removal of antibiotics in membrane processes can occur through multiple mechanisms. First, removal can be governed by adsorption where antibiotics that are hydrophobic or have strong hydrogen-bonding characteristics, readily adsorb to membranes at the initial stages of filtration. In many cases though, removal can occur through steady-state rejection due to either steric effects for uncharged solutes or combined steric and electrostatic effects for charged solutes. These mechanisms are dependent on the physicochemical properties of the compound (molecular weight cut-off (MWCO), $p K_{a}$, hydrophobicity/hydrophilicity), the solution ( $\mathrm{pH}$, ionic strength), and the membrane characteristics (material, surface morphology, pore size) (Le-Minh et al., 2010).

While the pores in micro- and ultrafiltration are too large to reject micropollutants, the lower membrane pore size used in nanofiltration (NF, pore size range: $0.001 \mu \mathrm{m}$ ) and reverse osmosis (RO, pore size range $<0.001 \mu \mathrm{m}$ ) have been shown in recent years to effectively remove low-molecular-weight pharmaceutical compounds, including antibiotics, during wastewater treatment. Various studies showed up to $90 \%$ removal of several antibiotics including quinolones, sulfonamides, tetracyclines and trimethoprim (Kimura et al., 2004; Morse and Jackson, 2004). A study undertaken by Kosutíc et al. (2007) on the treatment of model wastewater of a manufacturing plant producing pharmaceuticals for veterinary use showed that sulfonamides were effectively removed by NF and RO. Zhang et al. (2006) reported a high removal efficiency (98.5-99.7\%) for amoxicillin from wastewater, which contains high level of TOC using RO. In a study of $\mathrm{Li}$ et al. (2004) oxytetracycline at very high concentration (1000 $\mathrm{mg} \mathrm{L}^{-1}$ ) in wastewater from pharmaceutical manufacturing was reduced to $80 \mathrm{mg} \mathrm{L}^{-1}$ ( $<92 \%$ removal).

Given the complementary treatment capacity of MBR and $\mathrm{NF} / \mathrm{RO}$ membrane filtration, there is significant scope for the coupling of these two treatment processes to achieve an overall enhanced performance (Alturki et al., 2010; Dolar et al., 2012). Excellent overall removal of target antibiotics with removal rates above $99 \%$ was achieved with MBR/RO (Dolar et al., 2012).

Some investigations reveal that the fouling of membranes can also lead to improved rejection of many solutes (Schafer et al., 1994; Drewes et al., 2006; Xu et al., 2006). This interesting observation is believed to be due to increased negative surface charge leading to increased electrostatic rejection of ionic species; along with simultaneously increased adsorptive capacity for non-ionic solutes (Xu et al., 2006).

\subsection{Activated carbon adsorption treatment}

Adsorptive treatment with activated carbon can be used for removing many hydrophobic and also some charged pharmaceuticals from water (Le-Minh et al., 2010). The adsorption mainly involves the following steps: (i) solute transport in the bulk-adsorbate movement by the stagnant liquid film surrounding the adsorbent, (ii) film diffusion-adsorbate transport along the film, (iii) pores diffusion-adsorbate diffusion through the porous structure to the active sites (molecular diffusion in the pore and/or in the adsorbent surface), (iv) adsorption-interaction between adsorbate and porous structure (Homem and Santos, 2011).

The removal effectiveness of the activated carbon adsorptive treatment system depends on the properties of the adsorbent (e.g. specific surface area, porosity, surface polarity and physical shape of the material), and the characteristics of the compound (e.g. shape, size, charge and hydrophobicity). Moreover, the sorption efficiencies of antibiotics to activated carbon may be significantly altered by the initial concentrations of the target compounds, the $\mathrm{pH}$, the temperature and the presence of other species in the solution (Aksu and Tunç, 2005). Non-specific dispersive interactions (e.g. van der Waals interactions) are the dominant mechanism of removal for organic compounds, including antibiotics, in activated carbon adsorption systems, removing most non-polar antibiotics with $\log K_{\mathrm{Ow}}>2$. However, electrostatic interactions between ionic antibiotics and the charged groups on the surface of activated carbon can result in removal of polar antibiotics (Snyder et al., 2003). The removal of antibiotics by activated carbon has been reported during wastewater treatment in some studies (Adams et al., 2002; Westerhoff et al., 2005; Putra et al., 2009; Rivera-Utrilla et al., 2009; McArdell et al., 2011; Boehler et al., 2012). A post-treatment with powdered activated carbon (PAC) after biological treatment has been mostly investigated. The concentrations of several antibiotics in wastewater with PAC dosages between 10 and $20 \mathrm{mg} \mathrm{L}^{-1}$ have been reduced by $49-99 \%$ after $4 \mathrm{~h}$ contact time (Adams et al., 
Table 2 - Removal of antibiotics from wastewater effluents through advanced treatment processes.

treatment

\begin{tabular}{ccc} 
& Membrane flltation \\
\hline Type of & Initial & Treatment proces
\end{tabular}

Results/findings

(Removal efficiency)

Reference

Antibiotic Group

$\beta$-Lactams

Amoxicillin

Simulated wastewater (USA)

$10 \mathrm{mg} \mathrm{L}^{-1}$

RO: plate and frame configuration, ACM-LP fully aromatic polyamide low pressure advanced composite membrane

CAS effluent (Australia)

Wastewater from plant

manufacturing AMX (China)

$280 \mathrm{ng} \mathrm{L}^{-1}$

MF/RO plant: receives $\sim 10 \%$ of CAS effluent

Laboratory-scale cross flow RO unit. Two high-pressure

cross flow membrane cells (SS316, $155 \mathrm{~cm}^{2}$ ) mounted with

a flat-sheet polyamide RO membrane.

$\mathrm{TOC}=18925 \mathrm{mg} \mathrm{L}^{-1} \mathrm{COD}=80000 \mathrm{mg} \mathrm{L}^{-1}$

Cefaclo

Cephalexin

Penicillin V

Cloxacillin

Macrolides

Roxithromycin

Tylosin

Sulfonamides

Sulfamethoxazole

\begin{abstract}
CAS effluent (Australia)
CAS effluent (Australia)

CAS effluent (Australia)

CAS effluent (Australia)

CAS effluent (Australia)

CAS effluent (Australia)
\end{abstract}

CAS effluent (Australia)

Sulfadiazine

Model wastewater for veterinary

use (Croatia)

$980 \mathrm{ng} \mathrm{L}^{-1}$

$5600 \mathrm{ng} \mathrm{L}^{-1}$

$160 \mathrm{ng} \mathrm{L}^{-1}$

$320 \mathrm{ng} \mathrm{L}^{-1}$

$100 \mathrm{ng} \mathrm{L}^{-1}$

$55 \mathrm{ng} \mathrm{L}^{-1}$

$1 \mathrm{mg} \mathrm{L}^{-1}$

$500 \mathrm{ng} \mathrm{L}^{-1}$

$10 \mathrm{mg} \mathrm{L}^{-1}$

MF/RO plant: receives $\sim 10 \%$ of CAS effluent MF/RO plant: receives $\sim 10 \%$ of CAS effluent MF/RO plant: receives $\sim 10 \%$ of CAS effluent MF/RO plant: receives $~ 10 \%$ of CAS effluent

MF/RO plant: receives $\sim 10 \%$ of CAS effluent $\mathrm{MF} / \mathrm{RO}$ plant: receives $\sim 10 \%$ of CAS effluent

RO membranes: Polyamide (XLE); Cellulose acetate (SC-3100). Cross flow membrane unit with a flat-sheet membrane cell

Effective membrane area in the cell $=32 \mathrm{~cm}^{2}$ MF/RO plant: receives $\sim 10 \%$ of CAS effluent RO membranes: XLE; HR95PP; TFC-S.

NF membranes: NF90; HL Desal, Osmonics

Surface area of membranes: $10.8 \mathrm{~cm}^{2}$

Sulfaguanidine

Model wastewater for veterinar use (Croatia)

$10 \mathrm{mg} \mathrm{L}^{-1}$

RO membranes: XLE; HR95PP; TFC-S.

NF membranes: NF90; HL Desal, Osmonic

Surface area of membranes: $10.8 \mathrm{~cm}^{2}$

Sulfamethazine

Model wastewater for veterinary

use (Croatia)

$10 \mathrm{mg} \mathrm{L}^{-1}$

RO membranes: XLE; HR95PP; TFC-S.

NF membranes: NF90; HL Desal, Osmonics

Surface area of membranes: $10.8 \mathrm{~cm}^{2}$

Missouri River water (Jefferson City)

$50 \mu g \mathrm{~L}^{-1}$

Barnstead RO system: Model D2716, Cellulose acetat membrane D2731, Flow: 1.9 L min $^{-1}$

$50 \mu \mathrm{g} \mathrm{L}^{-1} \quad$ Barnstead RO system: Model D2716, Cellulose acetate membrane D2731, Flow: $1.9 \mathrm{~L} \mathrm{\text {min } ^ { - 1 }}$

Sulfathiazole

Missouri River water (Jefferson City)

Sulfamerazine

CAS effluent (Australia)

Missouri River water (Jefferson City)

$40 \mathrm{ng} \mathrm{L}^{-1}$

MF/RO plant: receives $\sim 10 \%$ of CAS effluent

Barnstead RO system: Model D2716, Cellulose acetate membrane D2731, Flow: $1.9 \mathrm{~L} \mathrm{~min}^{-1}$

Sulfachloropyridazin

Missouri River water (Jefferson City)
$50 \mu \mathrm{g} \mathrm{L} \mathrm{L}^{-1}$

$50 \mu \mathrm{g} \mathrm{L}{ }^{-1}$
Barnstead RO system: Model D2716,

membrane D2731, Flow: $1.9 \mathrm{~L} \mathrm{~min}^{-1}$
$(100 \%)$

Morse and Jackson, 2004

MF: $n d ;$ RO: $n d$

$\mathrm{RO}_{1}$

$\mathrm{TOC}=283.9 \mathrm{mg} \mathrm{L}^{-1}(98.5 \%)$

$\mathrm{COD}=800 \mathrm{mg} \mathrm{L}^{-1}(99.0 \%)$

$\mathrm{RO}_{2}$

TOC $=56.8 \mathrm{mg} \mathrm{L}^{-1}(99.7 \%)$

$\mathrm{COD}=240 \mathrm{mg} \mathrm{L}^{-1}(99.7 \%)$

$\mathrm{MF}: n d ; \mathrm{RO}: n d$

$\mathrm{MF}: n d ; \mathrm{RO}: n d$

MF: $125 \mathrm{ng} \mathrm{L}^{-1}$; RO: $15 \mathrm{ng} \mathrm{L}^{-1}$

MF: $10 \mathrm{ng} \mathrm{L}^{-1}$. RO: $5 \mathrm{ng} \mathrm{L}^{-1}$

XLE $(70 \%)$

SC-3100 (82\%)

MF: $445 \mathrm{ng} \mathrm{L}^{-1}$; RO: nd

XLE $(99.4 \%)$

HR95PP $(99.4 \%)$

TFC-S $(100 \%)$

NF90 (99.4 \%)

HL (88.5\%)

XLE (99.3\%)

HR95PP $(98.9 \%)$

TFC-S (100\%)

NF90 $(99.1 \%)$

HL $(67.3 \%)$

XLE (99.1\%)

HR95PP $(99.3 \%)$

TFC-S (100\%)

NF90 (99.4\%)

HL (96.3\%)

$(90.3 \%)$

$(90.3 \%)$

et al., 2007

Zhang et al., 2006

Watkinson et al., 2007 Watkinson et al., 2007

Watkinson et al., 2007

Watkinson et al., 2007 Watkinson et al., 2007

Kimura et al., 2004

Watkinson et al., 2007 Kosutíc et al., 2007

MF: nd; RO: nd

(90.3\%)

$(90.3 \%)$
Adams et al., 2002

Adams et al., 2002

Watkinson et al., 2007

Adams et al., 2002

Adams et al., 2002

(continued on next page) 
Table 2 - (continued)

\begin{tabular}{|c|c|c|c|c|c|}
\hline \multirow{2}{*}{$\begin{array}{l}\text { Advanced } \\
\text { treatment } \\
\text { process } \\
\text { Antibiotic Group }\end{array}$} & \multicolumn{5}{|c|}{ Membrane filtration } \\
\hline & $\begin{array}{c}\text { Type of } \\
\text { wastewater (location) }\end{array}$ & $\begin{array}{l}\text { Initial } \\
\text { concentration }\end{array}$ & Treatment process & $\begin{array}{l}\text { Results/findings } \\
\text { (Removal efficiency) }\end{array}$ & Reference \\
\hline Sulfadimethoxine & $\begin{array}{l}\text { Missouri River water } \\
\text { (Jefferson City) }\end{array}$ & $50 \mu g \mathrm{~L}^{-1}$ & $\begin{array}{l}\text { Barnstead RO system: Model D2716, Cellulose acetate } \\
\text { membrane D2731, Flow: } 1.9 \mathrm{~L} \mathrm{~min}^{-1} \text {. }\end{array}$ & $(90.3 \%)$ & Adams et al., 2002 \\
\hline $\begin{array}{l}\text { Sulfasalazine } \\
\text { Ouinolones }\end{array}$ & CAS effluent (Australia) & $60 \mathrm{ng} \mathrm{L}^{-1}$ & MF/RO plant: receives $\sim 10 \%$ of CAS effluent & MF: $55 \mathrm{ng} \mathrm{L}^{-1} ; \mathrm{RO}: n d$ & Watkinson et al., 2007 \\
\hline \multirow[t]{2}{*}{ Enrofloxacin } & $\begin{array}{l}\text { Model wastewater for veterinary } \\
\text { use (Croatia) }\end{array}$ & $10 \mathrm{mg} \mathrm{L}^{-1}$ & $\begin{array}{l}\text { RO membranes: XLE (Dow/FilmTec, Midland MI); HR95PP } \\
\text { (Dow/FilmTec, Midland MI); TFC-S (Koch Membrane } \\
\text { Systems, Wilmington, MA). } \\
\text { NF membranes: NF90 (Dow/FilmTec); HL Desal, Osmonics } \\
\text { (GE Infrastructure Water Process Techn.,Vista, CA). } \\
\text { Surface area of membranes: } 10.8 \mathrm{~cm}^{2}\end{array}$ & $\begin{array}{l}\text { XLE }(97.2 \%) \\
\text { HR95PP }(98.8 \%) \\
\text { TFC-S (100\%) } \\
\text { NF90 (99.1\%) } \\
\text { HL }(99.4 \%)\end{array}$ & Kosutíc et al., 2007 \\
\hline & CAS effluent (Australia) & $100 \mathrm{ng} \mathrm{L}^{-1}$ & MF/RO plant: receives $\sim 10 \%$ of CAS effluent & MF: $240 \mathrm{ng} \mathrm{L}^{-1} ; \mathrm{RO}: 10 \mathrm{ng} \mathrm{L}^{-1}$ & Watkinson et al., 2007 \\
\hline Norfloxacin & CAS effluent (Australia) & $240 \mathrm{ng} \mathrm{L}^{-1}$ & MF/RO plant: receives $\sim 10 \%$ of CAS effluent & MF: $190 \mathrm{ng} \mathrm{L}^{-1} ; \mathrm{RO}: 15 \mathrm{ng} \mathrm{L}^{-1}$ & Watkinson et al., 2007 \\
\hline Ciprofloxacin & CAS effluent (Australia) & $4600 \mathrm{ng} \mathrm{L}^{-1}$ & MF/RO plant: receives $\sim 10 \%$ of CAS effluent & MF: $170 \mathrm{ng} \mathrm{L}^{-1} ; \mathrm{RO}:$ nd & Watkinson et al., 2007 \\
\hline Nalidixic acid & CAS effluent (Australia) & $200 \mathrm{ng} \mathrm{L}^{-1}$ & MF/RO plant: receives $\sim 10 \%$ of CAS effluent & MF: $260 \mathrm{ng} \mathrm{L}^{-1}$; RO: $75 \mathrm{ng} \mathrm{L}^{-1}$ & Watkinson et al., 2007 \\
\hline & Missouri River water (Jefferson City) & $50 \mu g \mathrm{~L}^{-1}$ & $\begin{array}{l}\text { Barnstead RO system: Model D2716, Cellulose acetate } \\
\text { membrane D2731, Flow: } 1.9 \mathrm{~L} \mathrm{~min}^{-1} \text {. }\end{array}$ & $(90.3 \%)$ & Adams et al., 2002 \\
\hline & CAS effluent (Australia) & $930 \mathrm{ng} \mathrm{L}^{-1}$ & MF/RO plant: receives $\sim 10 \%$ of CAS effluent & MF: $85 \mathrm{ng} \mathrm{L}^{-1} ; \mathrm{RO}: 10 \mathrm{ng} \mathrm{L}^{-1}$ & Watkinson et al., 2007 \\
\hline & Secondary effluent ( Beijing, China) & $400 \mathrm{ng} \mathrm{L}^{-}$ & $\begin{array}{l}\text { UF: Dead-end ultrafiltration system (Zenon GE), } 6 \text { trains } \\
\text { of Zee-Weed } 1000 \text { membrane, pore size of } 0.02 \mu \mathrm{m} \text { (PVDF), } \\
\text { flow }=23 \mathrm{~L}\left(\mathrm{~m}^{2} \mathrm{~h}\right)^{-1} \\
\text { MF/RO: Spiral-wound cross flow module (Filmtec, DOW). }\end{array}$ & $\begin{array}{l}\text { UF }(0-50 \%) \\
\operatorname{MF} / \operatorname{RO}(>90 \%)\end{array}$ & Sui et al., 2010 \\
\hline \multicolumn{6}{|l|}{ Tetracyclines } \\
\hline \multirow[t]{2}{*}{ Oxytetracycline } & $\begin{array}{l}\text { Model wastewater for veterinary } \\
\text { use (Croatia) }\end{array}$ & $10 \mathrm{mg} \mathrm{L}^{-1}$ & $\begin{array}{l}\text { RO membranes: XLE (Dow/FilmTec, Midland MI); HR95PP } \\
\text { (Dow/FilmTec, Midland MI); TFC-S (Koch Membrane } \\
\text { Systems, Wilmington, MA). } \\
\text { NF membranes: NF90 (Dow/FilmTec); HL Desal, Osmonics } \\
\text { (GE Infrastructure Water Process Techn,Vista, CA). } \\
\text { Surface area of membranes: } 10.8 \mathrm{~cm}^{2}\end{array}$ & $\begin{array}{l}\text { XLE }(99.2 \%) \\
\text { HR95PP }(99.3 \%) \\
\text { TFC-S (100\%) } \\
\text { NF90 (99.0\%) } \\
\text { HL }(99.2 \%)\end{array}$ & Kosutíc et al., 2007 \\
\hline & $\begin{array}{l}\text { Waste liquor from the crystallization } \\
\text { unit in a pharmaceutical company } \\
\text { (Chi Feng, Inner Mongolia, China). }\end{array}$ & $1000 \mathrm{mg} \mathrm{L}^{-1}$ & $\begin{array}{l}\text { RO: SEPA CELL flat sheet membrane apparatus; } \\
\text { membrane area of } 155 \mathrm{~cm}^{2} . \\
\text { UF: } 0.3 \mathrm{MPa} \text {; UF membranes } \\
\text { of different molecular weight cut-off } \\
(3,10,30,50 \mathrm{~K} \mathrm{Da})\end{array}$ & $<80 \mathrm{mg} \mathrm{L}^{-1}(>92 \%)$ & Li et al., 2004 \\
\hline \multicolumn{6}{|l|}{ Lincosamides } \\
\hline Clindamycin & CAS effluent (Australia) & $5 \mathrm{ng} \mathrm{L}^{-1}$ & MF/RO plant: receives $\sim 10 \%$ of CAS effluent & $\begin{array}{l}\text { MF: } 10 \mathrm{ng} \mathrm{L}^{-1} \\
\text { RO: } 5 \mathrm{ng} \mathrm{L}^{-1}\end{array}$ & Watkinson et al., 2007 \\
\hline Lincomycin & CAS effluent (Australia) & $80 \mathrm{ng} \mathrm{L}^{-1}$ & MF/RO plant: receives $\sim 10 \%$ of CAS effluent & $\begin{array}{l}\text { MF: } 35 \mathrm{ng} \mathrm{L}^{-1} \\
\mathrm{RO}: 1 \mathrm{ng} \mathrm{L}^{-1}\end{array}$ & Watkinson et al., 2007 \\
\hline
\end{tabular}




\begin{tabular}{|c|c|c|c|c|c|}
\hline \multirow{2}{*}{$\begin{array}{l}\text { Advanced } \\
\text { treatment process } \\
\text { Antibiotic Group }\end{array}$} & \multicolumn{5}{|c|}{ ACTIVATED CARBON ADSORPTION } \\
\hline & $\begin{array}{c}\text { Type of } \\
\text { wastewater (location) }\end{array}$ & $\begin{array}{c}\text { Initial } \\
\text { concentration }\end{array}$ & Treatment process & $\begin{array}{l}\text { Results/findings } \\
\text { (Removal efficiency) }\end{array}$ & Reference \\
\hline \multicolumn{6}{|l|}{$\beta$-Lactams } \\
\hline Amoxicillin & $\begin{array}{l}\text { Real wastewater (P.T. Coronet } \\
\text { Crown) }\end{array}$ & $317 \mathrm{mg} \mathrm{L}^{-1}$ & $\begin{array}{l}\text { GAC: } B E T \text { surface area }=1092.951 \mathrm{~m}^{2} \mathrm{~g}^{-1} \text {, pore } \operatorname{size}<20 \mathrm{~A}^{\circ} \text {, } \\
\text { dose: } 1.5 \mathrm{~g} \text { per } 50 \mathrm{~mL} \text { solvent }\end{array}$ & $16.9 \mathrm{mg} \mathrm{L}^{-1}(94.67 \%)$ & Putra et al., 2009 \\
\hline Penicillin G & $\mathrm{Na}$ & $50-1000 \mathrm{mg} \mathrm{L}^{-1}$ & $\begin{array}{l}\text { HCI washed PAC: particle size }<0.15 \mathrm{~mm} \text {, BET surface } \\
\text { area }=1000 \mathrm{~m}^{2} \mathrm{~g}^{-1} \text {, bulk density }=0.46 \text {. } \\
0.1 \mathrm{~g} \text { PAC was treated with } 100 \mathrm{ml} \text { of } \mathrm{PG} \text { at a defined } \mathrm{pH} \text {, } \\
\text { temperature and initial PG concentration }\end{array}$ & $\begin{array}{l}\text { Adsorption }{ }_{\text {MAX }}: 375.0 \mathrm{mg} \mathrm{g}^{-1} \\
\left.\text { (pH: } 6.0,35^{\circ} \mathrm{C}\right) \\
\text { adsorption }(\%) \text { : } \\
\text { 44.0-290.0 }\left(25^{\circ} \mathrm{C}\right) \\
\text { 39.6-64.4 }\left(35^{\circ} \mathrm{C}\right) \\
\text { 24.6-51.6 }\left(45^{\circ} \mathrm{C}\right)\end{array}$ & Aksu and Tunç, 2005 \\
\hline \multicolumn{6}{|c|}{ - } \\
\hline Azithromycin & $\begin{array}{l}\text { Hospital wastewater after } \\
\text { treatment with MBR }\end{array}$ & $110 \mathrm{ng} \mathrm{L}^{-1}$ & $\begin{array}{l}\text { PAC Norit SAE Super, PAC retention time }=2 \text { days, } \\
\text { dose }=8-43 \mathrm{mg} \mathrm{L}^{-1} \text {, contact time }=3-5 \text { days }\end{array}$ & $\begin{array}{l}\text { PAC dose }=8 \mathrm{mg} \mathrm{L}^{-1}(20 \%) \\
\text { PAC dose }=23 \mathrm{mg} \mathrm{L}^{-1}(100 \%) \\
\text { PAC dose }=43 \mathrm{mg} \mathrm{L}^{-1}(100 \%)\end{array}$ & McArdell et al. 2011 \\
\hline Clarithromycin & $\begin{array}{l}\text { Hospital wastewater after } \\
\text { treatment with MBR }\end{array}$ & $1280 \mathrm{ng} \mathrm{L}^{-1}$ & $\begin{array}{l}\text { PAC Norit SAE Super, PAC retention time }=2 \text { days, } \\
\text { dose }=8-43 \mathrm{mg} \mathrm{L}^{-1} \text {, contact time }=3-5 \text { days }\end{array}$ & $\begin{array}{l}\text { PAC dose }=8 \mathrm{mg} \mathrm{L}^{-1}(100 \%) \\
\text { PAC dose }=23 \mathrm{mg} \mathrm{L}^{-1}(100 \%) \\
\text { PAC dose }=43 \mathrm{mg} \mathrm{L}^{-1}(100 \%)\end{array}$ & McArdell et al. 2011 \\
\hline Roxithromycin & $\begin{array}{l}\text { Membrane bioreactor operating in } \\
\text { a sequential mode (SMBR) }\end{array}$ & $4.5-6 \mu g \mathrm{~L}^{-1}$ & $\begin{array}{l}\text { PAC QP: } 1.665 \mathrm{~g} \mathrm{~cm}^{3} \text { real density; } 0.25 \mathrm{~g} \mathrm{~cm}^{3} \text { apparent } \\
\text { density; } 328.2 \mathrm{~m}^{2} \mathrm{~g}^{-1} \text { specific surface area. }\end{array}$ & $\mathrm{PAC}$ dose $=1 \mathrm{~g} \mathrm{~L}^{-1}(71-86 \%)$ & Serrano et al., 2011 \\
\hline Erythromycin & $\begin{array}{l}\text { Membrane bioreactor operating in } \\
\text { a sequential mode (SMBR) }\end{array}$ & $6.5-8.5 \mu \mathrm{g} \mathrm{L}{ }^{-1}$ & $\begin{array}{l}\text { PAC QP: } 1.665 \mathrm{~g} \mathrm{~cm}^{3} \text { real density; } 0.25 \mathrm{~g} \mathrm{~cm}^{3} \text { apparent } \\
\text { density; } 328.2 \mathrm{~m}^{2} \mathrm{~g}^{-1} \text { specific surface area. }\end{array}$ & PAC dose $=1 \mathrm{~g} \mathrm{~L}^{-1}(42-64 \%)$ & Serrano et al., 2011 \\
\hline Erythromycin $-\mathrm{H}_{2} \mathrm{O}$ & $\begin{array}{l}\text { Four matrices: Colorado River from } \\
\text { Lake Mead; Ohio River near } \\
\text { Louisville; Passaic River near Totowa; } \\
\text { Model water. }\end{array}$ & na & $\begin{array}{l}\text { Two PACs: AC } 800 \text { (Acticarb, Dunnellon, FL) and WPM } \\
\text { (Calgon Carbon Corp., Pittsburgh, PA). } \\
\text { Contact time }=4 \text { h; AC dose }=1-20 \mathrm{mg} \mathrm{L}^{-1}\end{array}$ & AC800 dose $=5 \mathrm{mg} \mathrm{L}^{-1}(20 \%)$ & Westerhoff et al., 2005 \\
\hline $\begin{array}{l}\text { Erythromycin \& } \\
\text { Erythromycin- } \mathrm{H}_{2} \mathrm{O}\end{array}$ & $\begin{array}{l}\text { Hospital wastewater after treatment } \\
\text { with MBR }\end{array}$ & $10 \mathrm{ng} \mathrm{L}^{-1}$ & $\begin{array}{l}\text { PAC Norit SAE Super, PAC retention time }=2 \text { days, } \\
\text { dose }=8-43 \mathrm{mg} \mathrm{L}^{-1} \text {, contact time }=3-5 \text { days }\end{array}$ & $\begin{array}{l}\text { PAC dose }=8 \mathrm{mg} \mathrm{L}^{-1}(>95 \%) \\
\text { PAC dose }=23 \mathrm{mg} \mathrm{L}^{-1}(>88 \%) \\
\text { PAC dose }=43 \mathrm{mg} \mathrm{L}^{-1}(>88 \%)\end{array}$ & McArdell et al., 2011 \\
\hline $\begin{array}{l}\text { Sulfonamides } \\
\text { Sulfamethoxazole }\end{array}$ & $\begin{array}{l}\text { Hospital wastewater after treatment } \\
\text { with MBR }\end{array}$ & $3230 \mathrm{ng} \mathrm{L}^{-1}$ & $\begin{array}{l}\text { PAC Norit SAE Super, PAC retention time }=2 \text { days, } \\
\text { dose }=8-43 \mathrm{mg} \mathrm{L}^{-1} \text {, contact time }=3-5 \text { days }\end{array}$ & $\begin{array}{l}\text { PAC dose }=8 \mathrm{mg} \mathrm{L}^{-1}(2 \%) \\
\text { PAC dose }=23 \mathrm{mg} \mathrm{L}^{-1}(33 \%) \\
\text { PAC dose }=43 \mathrm{mg} \mathrm{L}^{-1}(62 \%)\end{array}$ & McArdell et al., 2011 \\
\hline & $\begin{array}{l}\text { Four matrices: Colorado River from } \\
\text { Lake Mead; } \\
\text { Ohio River near Louisville; Passaic } \\
\text { River near } \\
\text { Totowa; Model water. }\end{array}$ & na & $\begin{array}{l}\text { Two PACs: AC800 (Acticarb, Dunnellon, FL) and WPM } \\
\text { (Calgon Carbon Corp., Pittsburgh, PA). } \\
\text { Contact time }=4 \mathrm{~h} \text {; AC dose }=1-20 \mathrm{mg} \mathrm{L}^{-1}\end{array}$ & AC800 dose $=5 \mathrm{mg} \mathrm{L}^{-1}(20 \%)$ & Westerhoff et al., 2005 \\
\hline Sulfamethazine & Missouri River water (Jefferson City). & $50 \mu g \mathrm{~L}^{-1}$ & PAC dose $=0-50 \mathrm{mg} \mathrm{L}^{-1} ;$ Contact time $=4 \mathrm{~h}$ & $\begin{array}{l}\text { AC dose }=10 \mathrm{mg} \mathrm{L}^{-1}(49 \%) \\
\text { AC dose }=20 \mathrm{mg} \mathrm{L}^{-1}(85 \%) \\
\text { AC dose }=50 \mathrm{mg} \mathrm{L}^{-1}(>90 \%)\end{array}$ & Adams et al., 2002 \\
\hline Sulfathiazole & Missouri River water (Jefferson City). & $50 \mu g \mathrm{~L}^{-1}$ & PAC dose $=0-50 \mathrm{mg} \mathrm{L}^{-1} ;$ Contact time $=4 \mathrm{~h}$ & $\begin{array}{l}\text { AC dose }=10 \mathrm{mg} \mathrm{L}^{-1}(70 \%) \\
\text { AC dose }=20 \mathrm{mg} \mathrm{L}^{-1}(85 \%) \\
\text { AC dose: } 50 \mathrm{mg} \mathrm{L}^{-1}(>90 \%)\end{array}$ & Adams et al., 2002 \\
\hline Sulfachloropyridazine & Missouri River water (Jefferson City). & $50 \mu g \mathrm{~L}^{-1}$ & PAC dose $=0-50 \mathrm{mg} \mathrm{L}^{-1} ;$ Contact time $=4 \mathrm{~h}$ & $\begin{array}{l}\text { AC dose }=10 \mathrm{mg} \mathrm{L}^{-1}(58 \%) \\
\text { AC dose }=20 \mathrm{mg} \mathrm{L}^{-1}(75 \%) \\
\text { AC dose }=50 \mathrm{mg} \mathrm{L}^{-1}(>90 \%)\end{array}$ & Adams et al., 2002. \\
\hline Sulfadimethoxine & Missouri River water (Jefferson City). & $50 \mu \mathrm{g} \mathrm{L}^{-1}$ & PAC dose $=0-50 \mathrm{mg} \mathrm{L}^{-1}$; Contact time $=4 \mathrm{~h}$ & $\begin{array}{l}\text { AC dose }=10 \mathrm{mg} \mathrm{L}^{-1}(50 \%) \\
\text { AC dose }=20 \mathrm{mg} \mathrm{L}^{-1}(80 \%) \\
\text { AC dose }=50 \mathrm{mg} \mathrm{L}^{-1}(>90 \%)\end{array}$ & Adams et al., 2002 \\
\hline & & & & & (continued on next page) \\
\hline
\end{tabular}


Antibiotic Group

\begin{tabular}{|c|c|c|c|c|c|}
\hline \multirow{2}{*}{ 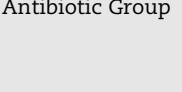 } & & & & & \\
\hline & $\begin{array}{c}\text { Type of } \\
\text { wastewater (location) }\end{array}$ & $\begin{array}{c}\text { Initial } \\
\text { concentration }\end{array}$ & Treatment process & $\begin{array}{l}\text { Results/findings } \\
\text { (Removal efficiency) }\end{array}$ & Reference \\
\hline Sulfadiazine & $\begin{array}{l}\text { Hospital wastewater after treatment } \\
\text { with MBR }\end{array}$ & $2330 \mathrm{ng} \mathrm{L}^{-1}$ & $\begin{array}{l}\text { PAC Norit SAE Super, PAC retention time }=2 \text { days, } \\
\text { dose }=8-43 \mathrm{mg} \mathrm{L}^{-1} \text {, contact time }=3-5 \text { days }\end{array}$ & $\begin{array}{l}\text { PAC dose }=8 \mathrm{mg} \mathrm{L}^{-1}(0 \%) \\
\text { PAC dose }=23 \mathrm{mg} \mathrm{L}^{-1}(40 \%) \\
\text { PAC dose }=43 \mathrm{mg} \mathrm{L}^{-1}(>40 \%)\end{array}$ & McArdell et al. 2011 \\
\hline Sulfapyridine & $\begin{array}{l}\text { Hospital wastewater after treatment } \\
\text { with MBR }\end{array}$ & $251 \mathrm{ng} \mathrm{L}^{-1}$ & $\begin{array}{l}\text { PAC Norit SAE Super, PAC retention time }=2 \text { days, } \\
\text { dose }=8-43 \mathrm{mg} \mathrm{L}^{-1} \text {, contact time }=3-5 \text { days }\end{array}$ & $\begin{array}{l}\text { PAC dose }=8 \mathrm{mg} \mathrm{L}^{-1}(85 \%) \\
\text { PAC dose }=23 \mathrm{mg} \mathrm{L}^{-1}(95 \%) \\
\text { PAC dose }=43 \mathrm{mg} \mathrm{L}^{-1}(>95 \%)\end{array}$ & McArdell et al. 2011 \\
\hline \multicolumn{6}{|l|}{ Quinolones } \\
\hline Ciprofloxacin & $\begin{array}{l}\text { Hospital wastewater after treatment } \\
\text { with MBR }\end{array}$ & $15700 \mathrm{ng} \mathrm{L}^{-1}$ & $\begin{array}{l}\text { PAC Norit SAE Super, PAC retention time }=2 \text { days, } \\
\text { dose }=8-43 \mathrm{mg} \mathrm{L}^{-1} \text {, contact time }=3-5 \text { days }\end{array}$ & $\begin{array}{l}\text { PAC dose }=8 \mathrm{mg} \mathrm{L}^{-1}(100 \%) \\
\text { PAC dose }=23 \mathrm{mg} \mathrm{L}^{-1}(>99 \%) \\
\text { PAC dose }=43 \mathrm{mg} \mathrm{L}^{-1}(>99 \%)\end{array}$ & McArdell et al. 2011 \\
\hline Norfloxacin & $\begin{array}{l}\text { Hospital wastewater after treatment } \\
\text { with MBR }\end{array}$ & $3140 \mathrm{ng} \mathrm{L}^{-1}$ & $\begin{array}{l}\text { PAC Norit SAE Super, PAC retention time }=2 \text { days, } \\
\text { dose }=8-43 \mathrm{mg} \mathrm{L}^{-1} \text {, contact time }=3-5 \text { days }\end{array}$ & $\begin{array}{l}\text { PAC dose }=8 \mathrm{mg} \mathrm{L}^{-1}(99 \%) \\
\text { PAC dose }=23 \mathrm{mg} \mathrm{L}^{-1}(>99 \%) \\
\text { PAC dose }=43 \mathrm{mg} \mathrm{L}^{-1}(>99 \%)\end{array}$ & McArdell et al. 2011 \\
\hline Trimethoprim & $\begin{array}{l}\text { Four matrices: Colorado River from } \\
\text { Lake Mead; } \\
\text { Ohio River near Louisville; Passaic } \\
\text { River near Totowa; Model water. }\end{array}$ & na & $\begin{array}{l}\text { Two PACs: AC800 (Acticarb, Dunnellon, FL) and WPM } \\
\text { (Calgon Carbon Corp., Pittsburgh, PA). } \\
\text { Contact time }=4 \mathrm{~h} \text {; AC dose }=1-20 \mathrm{mg} \mathrm{L}^{-1}\end{array}$ & AC800 dose $=5 \mathrm{mg} \mathrm{L}^{-1}(93 \%)$ & Westerhoff et al., 2005 \\
\hline & Missouri River water (Jefferson City). & $50 \mu \mathrm{g} \mathrm{L}{ }^{-1}$ & PAC dose $=0-50 \mathrm{mg} \mathrm{L}^{-1}$; Contact time $=4 \mathrm{~h}$ & $\begin{array}{l}\text { AC dose }=10 \mathrm{mg} \mathrm{L}^{-1}(55 \%) \\
\text { AC dose }=20 \mathrm{mg} \mathrm{L}^{-1}(65 \%) \\
\text { AC dose }=50 \mathrm{mg} \mathrm{L}^{-1}(>90 \%)\end{array}$ & Adams et al., 2002 \\
\hline & $\begin{array}{l}\text { Hospital wastewater after treatment } \\
\text { with MBR }\end{array}$ & $37 \mathrm{ng} \mathrm{L}^{-1}$ & $\begin{array}{l}\text { PAC Norit SAE Super, PAC retention time }=2 \text { days, } \\
\text { dose }=8-43 \mathrm{mg} \mathrm{L}^{-1} \text {, contact time }=3-5 \text { days }\end{array}$ & $\begin{array}{l}\text { PAC dose }=23 \mathrm{mg} \mathrm{L}^{-1}(>83 \%) \\
\text { PAC dose }=43 \mathrm{mg} \mathrm{L}^{-1}(>83 \%)\end{array}$ & McArdell et al. 2011 \\
\hline \multicolumn{6}{|l|}{ Tetracyclines } \\
\hline Tetracycline & na & na & $\begin{array}{l}\text { Four carbonaceous adsorbents: Single walled carbon } \\
\text { nanotubes (SWNT); Multi-walled carbon nanotubes } \\
\text { (MWNT); Pulverized activated carbon (AC) and } \\
\text { nonporous Graphite (G). }\end{array}$ & $\begin{array}{l}\text { Adsorption efficiency: G/ } \\
\text { SWNT > MWNT >> AC }\end{array}$ & Ji et al., 2009 \\
\hline \multicolumn{6}{|c|}{ 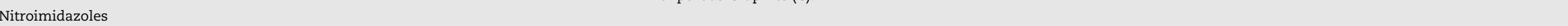 } \\
\hline Metronidazole & $\begin{array}{l}\text { Hospital wastewater after treatment } \\
\text { with MBR }\end{array}$ & $1860 \mathrm{ng} \mathrm{L}^{-1}$ & $\begin{array}{l}\text { PAC Norit SAE Super, PAC retention time }=2 \text { days, } \\
\text { dose }=8-43 \mathrm{mg} \mathrm{L}^{-1} \text {, contact time }=3-5 \text { days }\end{array}$ & $\begin{array}{l}\text { PAC dose }=8 \mathrm{mg} \mathrm{L}^{-1}(3 \%) \\
\text { PAC dose }=23 \mathrm{mg} \mathrm{L}^{-1}(67 \%) \\
\text { PAC dose }=43 \mathrm{mg} \mathrm{L}^{-1}(78 \%)\end{array}$ & McArdell et al. 2011 \\
\hline Metronidazole & Motril (Granada) & $100-600 \mathrm{mg} \mathrm{L}^{-1}$ & $\begin{array}{l}\text { Three activated carbons }(0.1 \mathrm{~g}) \text { : Sorbo }(\mathrm{S}) \text {; Merck }(\mathrm{M}) \\
\text { and carbon prepared by chemical activation of } \\
\text { petroleum coke with KOH (C). } \\
\mathrm{S}\left(\mathrm{BET}=1225 \mathrm{~m}^{2} \mathrm{~g}^{-1}\right) ; \mathrm{M}\left(\mathrm{BET}=1301 \mathrm{~m}^{2} \mathrm{~g}^{-1}\right) \text {; C (BET } \\
\left.=848 \mathrm{~m}^{2} \mathrm{~g}^{-1}\right)\end{array}$ & $\begin{array}{l}\text { Adsorption capacity } \\
\text { S: } 1.92 \mathrm{mmol} \mathrm{g}^{-1} \\
\text { M: } 1.25 \mathrm{mmol} \mathrm{g}^{-1} \\
\text { C: } 1.68 \mathrm{mmol} \mathrm{g}^{-1}\end{array}$ & Rivera-Utrilla et al., 2009 \\
\hline Dimetridazole & Motril (Granada) & $100-600 \mathrm{mg} \mathrm{L}^{-1}$ & $\begin{array}{l}\text { Three activated carbons }(0.1 \mathrm{~g}) \text { : Sorbo }(\mathrm{S}) \text {; Merck }(\mathrm{M}) \\
\text { and carbon prepared by chemical activation of petroleum } \\
\text { coke with KOH (C). } \\
\mathrm{S}\left(\mathrm{BET}=1225 \mathrm{~m}^{2} \mathrm{~g}^{-1}\right) ; \mathrm{M}\left(\mathrm{BET}=1301 \mathrm{~m}^{2} \mathrm{~g}^{-1}\right) ; \mathrm{C}\left(\mathrm{BET}=848 \mathrm{~m}^{2} \mathrm{~g}^{-1}\right)\end{array}$ & $\begin{array}{l}\text { Adsorption capacity } \\
\text { S: } 1.99 \mathrm{mmol} \mathrm{g}^{-1} \\
\text { M: } 1.32 \mathrm{mmol} \mathrm{g}^{-1} \\
\text { C: } 2.04 \mathrm{mmol} \mathrm{g}^{-1}\end{array}$ & Rivera-Utrilla et al., 2009 \\
\hline Tinidazole & Motril (Granada) & $100-600 \mathrm{mg} \mathrm{L}^{-1}$ & $\begin{array}{l}\text { Three activated carbons }(0.1 \mathrm{~g}) \text { : Sorbo }(\mathrm{S}) \text {; Merck }(\mathrm{M}) \text { and carbon } \\
\text { prepared by chemical activation of petroleum coke with } \mathrm{KOH}(\mathrm{C}) \text {. } \\
\mathrm{S}\left(\mathrm{BET}=1225 \mathrm{~m}^{2} \mathrm{~g}^{-1}\right) ; \mathrm{M}\left(\mathrm{BET}=1301 \mathrm{~m}^{2} \mathrm{~g}^{-1}\right) \text {; } \\
\left.\text { C (BET }=848 \mathrm{~m}^{2} \mathrm{~g}^{-1}\right)\end{array}$ & $\begin{array}{l}\text { Adsorption capacity } \\
\text { S: } 1.37 \mathrm{mmol} \mathrm{g}^{-1} \\
\text { M: } 1.56 \mathrm{mmol} \mathrm{g}^{-1} \\
\text { C: } 1.04 \mathrm{mmol} \mathrm{g}^{-1}\end{array}$ & Rivera-Utrilla et al., 2009 \\
\hline Ronidazole & Motril (Granada) & $100-600 \mathrm{mg} \mathrm{L}^{-1}$ & $\begin{array}{l}\text { Three activated carbons }(0.1 \mathrm{~g}) \text { : Sorbo }(\mathrm{S}) \text {; Merck }(\mathrm{M}) \text { and carbon } \\
\text { prepared by chemical activation of petroleum coke with KOH }(\mathrm{C}) \text {. } \\
\mathrm{S}\left(\mathrm{BET}=1225 \mathrm{~m}^{2} \mathrm{~g}^{-1}\right) ; \mathrm{M}\left(\mathrm{BET}=1301 \mathrm{~m}^{2} \mathrm{~g}^{-1}\right) ; \mathrm{C}\left(\mathrm{BET}=848 \mathrm{~m}^{2} \mathrm{~g}^{-1}\right)\end{array}$ & $\begin{array}{l}\text { Adsorption capacity } \\
\text { S: } 1.97 \mathrm{mmol} \mathrm{g}^{-1} \\
\text { M: } 1.82 \mathrm{mmol} \mathrm{g}^{-1} \\
\text { C: } 1.89 \mathrm{mmol} \mathrm{g}^{-1}\end{array}$ & Rivera-Utrilla et al., 2009 \\
\hline
\end{tabular}




\begin{tabular}{|c|c|c|c|c|c|}
\hline Clindamycin & $\begin{array}{l}\text { Hospital wastewater after treatment } \\
\text { with MBR }\end{array}$ & $1160 \mathrm{ng} \mathrm{L}^{-1}$ & $\begin{array}{l}\text { PAC Norit SAE Super, PAC retention time }=2 \text { days, dose }= \\
8-43 \mathrm{mg} \mathrm{L}^{-1} \text {, contact time }=3-5 \text { days }\end{array}$ & $\begin{array}{l}\text { PAC dose }=8 \mathrm{mg} \mathrm{L}^{-1}(96 \%) \\
\text { PAC dose }=23 \mathrm{mg} \mathrm{L}^{-1}(>99 \%) \\
\text { PAC dose }=43 \mathrm{mg} \mathrm{L}^{-1}(100 \%)\end{array}$ & McArdell et al. 2011 \\
\hline \multirow{2}{*}{$\begin{array}{l}\text { Advanced } \\
\text { treatment process } \\
\text { Antibiotic Group }\end{array}$} & \multicolumn{5}{|c|}{ OZONATION } \\
\hline & $\begin{array}{c}\text { Type of } \\
\text { wastewater (location) }\end{array}$ & $\begin{array}{c}\text { Initial } \\
\text { concentration }\end{array}$ & Treatment process & $\begin{array}{l}\text { Results/findings } \\
\text { (Removal efficiency) }\end{array}$ & Reference \\
\hline \multicolumn{6}{|l|}{$\beta$-Lactams } \\
\hline Cephalexin & $\begin{array}{l}\text { Secondary effluent (Kloten-Opfikon, } \\
\text { Switzerland) }\end{array}$ & $1 \mu \mathrm{M}$ & $\begin{array}{l}\text { Batch experiments, } O_{3} \text { dose }=0.5-5.0 \mathrm{mg} \mathrm{L}^{-1} \\
\text { DOC }=5.3 \mathrm{mg} \mathrm{L}^{-1}\end{array}$ & $\mathrm{O}_{3}$ dose $=3 \mathrm{mg} \mathrm{L}^{-1}(100 \%)$ & Dodd et al., 2006 \\
\hline \multirow[t]{2}{*}{ Penicillin } & $\begin{array}{l}\text { Antibiotic formulation effluent } \\
\text { (Turkey) }\end{array}$ & na & $\begin{array}{l}\mathrm{O}_{3} \text { dose }=2500 \mathrm{mg}(\mathrm{L} \mathrm{h})^{-1} ; \mathrm{pH}=2.5-12.0 \\
\left.\mathrm{O}_{3}+\mathrm{H}_{2} \mathrm{O}_{2}\left[\mathrm{H}_{2} \mathrm{O}_{2}\right]=2-40 \mathrm{mM}\right) ; \mathrm{pH}=10.5\end{array}$ & $\begin{array}{l}\text { COD removal } \\
\mathrm{O}_{3}:(10-56 \%) \\
\mathrm{O}_{3}+\mathrm{H}_{2} \mathrm{O}_{2}(20 \mathrm{mM}):(83 \%)\end{array}$ & Arslan Alaton et al., 2004 \\
\hline & $\begin{array}{l}\text { Antibiotic formulation effluent } \\
\text { (Turkey) }\end{array}$ & na & $\mathrm{O}_{3}$ dose $=2760 \mathrm{mg}(\mathrm{L} \mathrm{h})^{-1} ; \mathrm{pH}=3-11.5$ & $\begin{array}{l}\text { COD removal } \\
\mathrm{O}_{3} / \mathrm{pH} \mathrm{3:}(15 \%) \\
\mathrm{O}_{3} / \mathrm{pH} 7:(28 \%) \\
\mathrm{O}_{3} / \mathrm{pH} \mathrm{11:}(49 \%) \\
\text { TOC removal } \\
\mathrm{O}_{3} / \mathrm{pH} \mathrm{3:}(2 \%) \\
\mathrm{O}_{3} / \mathrm{pH} 7:(23 \%) \\
\mathrm{O}_{3} / \mathrm{pH} \mathrm{11:}(52 \%)\end{array}$ & $\begin{array}{l}\text { Arslan Alaton and } \\
\text { Dogruel, } 2004\end{array}$ \\
\hline Penicillin & $\begin{array}{l}\text { Secondary effluent (Kloten-Opfikon, } \\
\text { Switzerland) }\end{array}$ & $1 \mu \mathrm{M}$ & $\begin{array}{l}\text { Batch experiments, } \mathrm{O}_{3} \text { dose }=0.5-5.0 \mathrm{mg} \mathrm{L}^{-1} \\
\text { DOC }=5.3 \mathrm{mg} \mathrm{L}^{-1}\end{array}$ & $\mathrm{O}_{3}$ dose $=5 \mathrm{mg} \mathrm{L}^{-1}(100 \%)$ & Dodd et al., 2006 \\
\hline Penicillin V & Synthetic wastewater (Turkey) & na & $\begin{array}{l}\left.\text { (a) } \mathrm{O}_{3} \text { (flow }=100 \mathrm{~L} \mathrm{~h}^{-1}, \mathrm{O}_{3} \text { dose }=2.96 \mathrm{~g} \mathrm{~L}^{-1} \mathrm{~h}^{-1}\right) \text {; } \\
\text { (b) } \mathrm{O}_{3} / \mathrm{H}_{2} \mathrm{O}_{2}\left(\left[\mathrm{H}_{2} \mathrm{O}_{2}\right]=20 \mathrm{mM}\right)\end{array}$ & $\begin{array}{l}\text { (a) }(80 \% \text { in } 60 \mathrm{~min}) \\
\text { (b) }(100 \% \text { in } 60 \mathrm{~min})\end{array}$ & $\begin{array}{l}\text { Balcıoglu and Otker, } \\
2003\end{array}$ \\
\hline Ceftriaxone & Synthetic wastewater (Turkey) & na & $\begin{array}{l}\left.\text { (a) } \mathrm{O}_{3} \text { (flow }=100 \mathrm{~L} \mathrm{~h}^{-1}, \mathrm{O}_{3} \text { dose }=2.96 \mathrm{~g} \mathrm{~L}^{-1} \mathrm{~h}^{-1}\right) \text {; } \\
\text { (b) } \mathrm{O}_{3} / \mathrm{H}_{2} \mathrm{O}_{2}\left(\left[\mathrm{H}_{2} \mathrm{O}_{2}\right]=20 \mathrm{mM}\right)\end{array}$ & $\begin{array}{l}\text { (a) (>99\% in } 60 \mathrm{~min}) \\
\text { (b) }(100 \% \text { in } 60 \mathrm{~min})\end{array}$ & $\begin{array}{l}\text { Balc1oglu and Otker, } \\
2003\end{array}$ \\
\hline \multicolumn{6}{|l|}{ Macrolides } \\
\hline \multirow[t]{6}{*}{ Roxithromycin } & $\begin{array}{l}\text { Secondary effluent (Kloten-Opfikon, } \\
\text { Switzerland) }\end{array}$ & $1 \mu \mathrm{M}$ & $\begin{array}{l}\text { Batch experiments, } \mathrm{O}_{3} \text { dose }=0.5-5.0 \mathrm{mg} \mathrm{L}^{-1} \\
\mathrm{DOC}=5.3 \mathrm{mg} \mathrm{L}^{-1}\end{array}$ & $\mathrm{O}_{3}$ dose $=1 \mathrm{mg} \mathrm{L}^{-1}(55 \%)$ & Dodd et al., 2006 \\
\hline & $\begin{array}{l}\text { CAS and MBR effluent (Kloten-Opfikon, } \\
\text { Switzerland) }\end{array}$ & $2 \mu \mathrm{L}^{-1}$ & $\mathrm{O}_{3}$ dose $=0-5 \mathrm{mg} \mathrm{L}^{-1}$; flow $=200 \pm 10 \mathrm{~L} \mathrm{~h}^{-1}$ (only column 1). & $\mathrm{O}_{3}$ dose $\geq 2 \mathrm{mg} \mathrm{L}^{-1}(\geq 90 \%)$ & Huber et al., 2005 \\
\hline & Secondary effluent (German) & $0.54 \pm 0.04 \mu g \mathrm{~L}^{-1}$ & $\begin{array}{l}\text { Ozonation-UV treatment plant } \\
\mathrm{O}_{3} 100 \mathrm{~g} \mathrm{~h}^{-1}, \mathrm{O}_{3} \text { dose } 5-15 \mathrm{mg} \mathrm{L}^{-1}, 2 \text { diffuser/PVC bubble } \\
\text { columns }\end{array}$ & $\mathrm{O}_{3}$ dose $=5-15 \mathrm{mg} \mathrm{L}^{-1}(\geq 91 \%)$ & Ternes et al., 2003 \\
\hline & $\begin{array}{l}\text { Secondary wastewater effluent } \\
\text { (Spain) }\end{array}$ & na & Batch experiments, $\mathrm{O}_{3}$ flow $=35 \mathrm{~L} \mathrm{~h}^{-1}, \mathrm{O}_{3}$ dose $=20 \mathrm{mg} \mathrm{L}^{-1}$. & $(100 \%)$ & Radjenovic et al., 2009a \\
\hline & CAS and sand filtration (Tokyo) & $27.2 \mathrm{ng} \mathrm{L}^{-1}$ & $\mathrm{O}_{3}$ dose $=3 \mathrm{mg} \mathrm{L}^{-1}$, Retention time $=27 \mathrm{~min}$ & $(90.9 \%)$ & Nakada et al., 2007 \\
\hline & $\begin{array}{l}\text { CAS effluent (Regensdorf, } \\
\text { Switzerland) }\end{array}$ & $9 \mathrm{ng} \mathrm{L}^{-1}$ & $\begin{array}{l}\mathrm{O}_{3} \text { dose }=1.6-5.3 \mathrm{mg} \mathrm{L}^{-1}\left(0.36-1.16 \mathrm{~g} \mathrm{~g}^{-1} \mathrm{DOC}\right) \text {, Retention } \\
\text { time }=8-15 \mathrm{~min} \text {, full scale six compartment reactor }\end{array}$ & $\begin{array}{l}\mathrm{O}_{3} \text { dose }=0.40 \mathrm{~g} \mathrm{~g}^{-1} \mathrm{DOC}(77 \%) \\
\mathrm{O}_{3} \text { dose }=0.62 \mathrm{~g} \mathrm{~g}^{-1} \mathrm{DOC}(80 \%)\end{array}$ & Hollender et al., 2009 \\
\hline \multirow[t]{4}{*}{ Azithromycin } & $\begin{array}{l}\text { Secondary effluent (Kloten-Opfikon, } \\
\text { Switzerland) }\end{array}$ & $1 \mu \mathrm{M}$ & $\begin{array}{l}\text { Batch experiments, } \mathrm{O}_{3} \text { dose }=0.5-5.0 \mathrm{mg} \mathrm{L}^{-1} \\
\mathrm{DOC}=5.3 \mathrm{mg} \mathrm{L}^{-1}\end{array}$ & $\mathrm{O}_{3}$ dose: $1 \mathrm{mg} \mathrm{L}^{-1}(62 \%)$ & Dodd et al., 2006 \\
\hline & CAS and sand filtration (Tokyo) & nd & $\mathrm{O}_{3}$ dose $=3 \mathrm{mg} \mathrm{L}^{-1}$, Retention time $=27 \mathrm{~min}$ & $(92.6 \%)$ & Nakada et al., 2007 \\
\hline & CAS effluent (Alcala de Henares, Madrid) & $235 \mathrm{ng} \mathrm{L}^{-1}$ & AirSep AS-12 PSA oxygen generation unit & $\mathrm{O}_{3}$ dose $<50 \mu \mathrm{M}(100 \%)$ & Rosal et al., 2010 \\
\hline & $\begin{array}{l}\text { CAS effluent (Regensdorf, } \\
\text { Switzerland) }\end{array}$ & $100 \mathrm{ng} \mathrm{L}^{-1}$ & $\begin{array}{l}\mathrm{O}_{3} \text { dose }=1.6-5.3 \mathrm{mg} \mathrm{L}^{-1}\left(0.36-1.16 \mathrm{~g} \mathrm{~g}^{-1} \mathrm{DOC}\right) \text {, Retention } \\
\text { time }=8-15 \mathrm{~min} \text {, full scale six compartment reactor }\end{array}$ & $\mathrm{O}_{3}$ dose $=0.61 \mathrm{~g} \mathrm{~g}^{-1} \mathrm{DOC}(>99 \%)$ & Hollender et al., 2009 \\
\hline \multirow[t]{2}{*}{ Tylosin } & $\begin{array}{l}\text { Secondary effluent (Kloten-Opfikon, } \\
\text { Switzerland) }\end{array}$ & $1 \mu \mathrm{M}$ & $\begin{array}{l}\text { Batch experiments, } \mathrm{O}_{3} \text { dose }=0.5-5.0 \mathrm{mg} \mathrm{L}^{-1} \\
\mathrm{DOC}=5.3 \mathrm{mg} \mathrm{L}^{-1}\end{array}$ & $\mathrm{O}_{3}$ dose $=3 \mathrm{mg} \mathrm{L}^{-1}(100 \%)$ & Dodd et al., 2006 \\
\hline & Pharmaceutical effluent (Taiwan) & $40 \mathrm{mg} \mathrm{L}^{-1}$ & $\mathrm{O}_{3} / \mathrm{O}_{2}$ mixture, $\mathrm{O}_{3}$ dose $(\mathrm{v} / \mathrm{v})=5.3 \%$, flow $=1.6 \mathrm{~L} \mathrm{~min}^{-1}$. & $(>99 \%)$ & $\begin{array}{l}\text { Lin et al., 2009b } \\
\text { (continued on next page) }\end{array}$ \\
\hline
\end{tabular}


Antibiotic Group

\begin{tabular}{|c|c|c|c|c|c|}
\hline Antibiotic Group & $\begin{array}{c}\text { Type of } \\
\text { wastewater (location) }\end{array}$ & $\begin{array}{c}\text { Initial } \\
\text { concentration }\end{array}$ & Treatment process & $\begin{array}{c}\text { Results/findings } \\
\text { (Removal efficiency) }\end{array}$ & Reference \\
\hline \multirow[t]{4}{*}{ Clarithromycin } & Secondary effluent (German) & $0.21 \pm 0.02 \mu \mathrm{g} \mathrm{L}^{-1}$ & $\begin{array}{l}\text { Ozonation-UV treatment plant } \\
\mathrm{O}_{3}=100 \mathrm{~g} \mathrm{~h}^{-1}, \mathrm{O}_{3} \text { dose }=5-15 \mathrm{mg} \mathrm{L}^{-1}, 2 \text { diffuser/PVC } \\
\text { bubble columns }\end{array}$ & $\mathrm{O}_{3}$ dose $=5-15 \mathrm{mg} \mathrm{L}^{-1}(\geq 76 \%)$ & Ternes et al., 2003 \\
\hline & CAS and sand filtration (Tokyo) & $228 \mathrm{ng} \mathrm{L}^{-1}$ & $\mathrm{O}_{3}$ dose $=3 \mathrm{mg} \mathrm{L}^{-1}$, Retention time $=27 \mathrm{~min}$ & $(84.69 \%)$ & Nakada et al., 2007 \\
\hline & $\begin{array}{l}\text { CAS effluent (Alcala de Henares, } \\
\text { Madrid) }\end{array}$ & $39 \mathrm{ng} \mathrm{L}^{-1}$ & AirSep AS-12 PSA oxygen generation unit & $\mathrm{O}_{3}$ dose $<50 \mu \mathrm{M}(100 \%)$ & Rosal et al., 2010 \\
\hline & $\begin{array}{l}\text { CAS effluent (Regensdorf, } \\
\text { Switzerland) }\end{array}$ & $206 \mathrm{ng} \mathrm{L}^{-1}$ & $\begin{array}{l}\mathrm{O}_{3} \text { dose }=1.6-5.3 \mathrm{mg} \mathrm{L}^{-1}\left(0.36-1.16 \mathrm{~g} \mathrm{~g}^{-1} \mathrm{DOC}\right) \text {, Retention } \\
\text { time }=8-15 \mathrm{~min} \text {, full scale six compartment reactor }\end{array}$ & $\begin{array}{l}\mathrm{O}_{3} \text { dose }=0.40 \mathrm{~g} \mathrm{~g}^{-1} \mathrm{DOC}(94 \%) \\
\mathrm{O}_{3} \text { dose }=0.62 \mathrm{~g} \mathrm{~g}^{-1} \mathrm{DOC}(97 \%) \\
\mathrm{O}_{3} \text { dose }=0.79 \mathrm{~g} \mathrm{~g}^{-1} \mathrm{DOC}(99 \%)\end{array}$ & Hollender et al., 2009 \\
\hline \multirow[t]{4}{*}{ Erythromycin } & Secondary effluent (German) & $0.62 \pm 0.24 \mu \mathrm{g} \mathrm{L}^{-1}$ & $\begin{array}{l}\text { Ozonation-UV treatment plant } \\
\mathrm{O}_{3}=100 \mathrm{~g} \mathrm{~h}^{-1}, \mathrm{O}_{3} \text { dose }=5-15 \mathrm{mg} \mathrm{L}^{-1}, 2 \text { diffuser/PVC } \\
\text { bubble columns }\end{array}$ & $\mathrm{O}_{3}$ dose $=5-15 \mathrm{mg} \mathrm{L}^{-1}(\geq 92 \%)$ & Ternes et al., 2003 \\
\hline & $\begin{array}{l}\text { CAS effluent (Alcala de Henares, } \\
\text { Madrid) }\end{array}$ & $72 \mathrm{ng} \mathrm{L}^{-1}$ & AirSep AS-12 PSA oxygen generation unit & $\mathrm{O}_{3}$ dose $<90 \mu \mathrm{M}(100 \%)$ & Rosal et al., 2010 \\
\hline & Pharmaceutical effluent (Taiwan) & $40 \mathrm{mg} \mathrm{L}^{-1}$ & $\mathrm{O}_{3} / \mathrm{O}_{2}$ mixture, $\mathrm{O}_{3}$ dose $(\mathrm{v} / \mathrm{v})=5.3 \%$, flow $=1.6 \mathrm{~L} \mathrm{~min}{ }^{-1}$ & $(>99 \%)$ & Lin et al., 2009b \\
\hline & $\begin{array}{l}\text { CAS effluent (Regensdorf, } \\
\text { Switzerland) }\end{array}$ & $36 \mathrm{ng} \mathrm{L}^{-1}$ & $\begin{array}{l}\mathrm{O}_{3} \text { dose }=1.6-5.3 \mathrm{mg} \mathrm{L}^{-1}\left(0.36-1.16 \mathrm{~g} \mathrm{~g}^{-1} \mathrm{DOC}\right) \text {, Retention } \\
\text { time }=8-15 \mathrm{~min} \text {, full scale six compartment reactor }\end{array}$ & $\mathrm{O}_{3}$ dose $=0.61 \mathrm{~g} \mathrm{~g}^{-1} \mathrm{DOC}(>64 \%)$ & Hollender et al., 2009 \\
\hline $\begin{array}{l}\text { Erythromycin- } \mathrm{H}_{2} \mathrm{O} \\
\text { Sulfonamides }\end{array}$ & CAS and sand filtration (Tokyo) & $150 \mathrm{ng} \mathrm{L}^{-1}$ & $\mathrm{O}_{3}$ dose $=3 \mathrm{mg} \mathrm{L}^{-1}$, Retention time $=27 \mathrm{~min}$ & $(88.7 \%)$ & Nakada et al., 2007 \\
\hline \multirow[t]{6}{*}{ Sulfamethoxazole } & $\begin{array}{l}\text { Secondary effluent (Kloten-Opfikon, } \\
\text { Switzerland) }\end{array}$ & $1 \mu \mathrm{M}$ & $\begin{array}{l}\text { Batch experiments, } \mathrm{O}_{3} \text { dose }=0.5-5.0 \mathrm{mg} \mathrm{L}^{-1} \\
\mathrm{DOC}=5.3 \mathrm{mg} \mathrm{L}^{-1}\end{array}$ & $\mathrm{O}_{3}$ dose $=3 \mathrm{mg} \mathrm{L}^{-1}(100 \%)$ & Dodd et al., 2006 \\
\hline & $\begin{array}{l}\text { CAS and MBR effluent (Kloten-Opfikon, } \\
\text { Switzerland) }\end{array}$ & $2 \mu \mathrm{g} \mathrm{L}-1$ & $\mathrm{O}_{3}$ dose $=0-5 \mathrm{mg} \mathrm{L}^{-1}$; flow $=200 \pm 10 \mathrm{~L} \mathrm{~h}^{-1}$ (only column 1). & $\begin{array}{l}\mathrm{O}_{3} \text { dose } \geq 2 \mathrm{mg} \mathrm{L}^{-1} \\
(\geq 90 \%)\end{array}$ & Huber et al., 2005 \\
\hline & CAS and sand filtration (Tokyo) & $104 \mathrm{ng} \mathrm{L}^{-1}$ & $\mathrm{O}_{3}$ dose $=3 \mathrm{mg} \mathrm{L}^{-1}$, Retention time $=27 \mathrm{~min}$ & $(87.4 \%)$ & Nakada et al., 2007 \\
\hline & $\begin{array}{l}\text { CAS effluent (Alcala de Henares, } \\
\text { Madrid) }\end{array}$ & $95 \mathrm{ng} \mathrm{L}^{-1}$ & AirSep AS-12 PSA oxygen generation unit & $\mathrm{O}_{3}$ dose $<220 \mu \mathrm{M}(100 \%)$ & Rosal et al., 2010 \\
\hline & Pharmaceutical effluent (Taiwan) & $40 \mathrm{mg} \mathrm{L}^{-1}$ & $\mathrm{O}_{3} / \mathrm{O}_{2}$ mixture, $\mathrm{O}_{3}$ dose $(\mathrm{v} / \mathrm{v})=5.3 \%$, flow $=1.6 \mathrm{~L} \mathrm{~min}^{-1}$. & $(93 \%)$ & Lin et al., 2009b \\
\hline & $\begin{array}{l}\text { CAS effluent (Regensdorf, } \\
\text { Switzerland) }\end{array}$ & $197 \mathrm{ng} \mathrm{L}^{-1}$ & $\begin{array}{l}\mathrm{O}_{3} \text { dose }=1.6-5.3 \mathrm{mg} \mathrm{L}^{-1}\left(0.36-1.16 \mathrm{~g} \mathrm{~g}^{-1} \mathrm{DOC}\right) \text {, Retention } \\
\text { time }=8-15 \mathrm{~min} \text {, full scale six compartment reactor }\end{array}$ & $\begin{array}{l}\mathrm{O}_{3} \text { dose }=0.40 \mathrm{~g} \mathrm{~g}^{-1} \mathrm{DOC}(87 \%) \\
\mathrm{O}_{3} \text { dose }=0.62 \mathrm{~g} \mathrm{~g}^{-1} \mathrm{DOC}(96 \%) \\
\mathrm{O}_{3} \text { dose }=0.79 \mathrm{~g} \mathrm{~g} \mathrm{~g}^{-1} \mathrm{DOC}(96 \%)\end{array}$ & Hollender et al., 2009 \\
\hline \multirow[t]{3}{*}{ Sulfamethazine } & Secondary effluent (German) & $0.62 \pm 0.05 \mu \mathrm{g} \mathrm{L}-1$ & $\begin{array}{l}\text { Ozonation-UV treatment plant } \\
\mathrm{O}_{3}=100 \mathrm{~g} \mathrm{~h}^{-1}, \mathrm{O}_{3} \text { dose }=5-15 \mathrm{mg} \mathrm{L}^{-1}, 2 \text { diffuser/PVC } \\
\text { bubble columns. }\end{array}$ & $\mathrm{O}_{3}$ dose $=5-15 \mathrm{mg} \mathrm{L}^{-1}(\geq 92 \%)$ & Ternes et al., 2003 \\
\hline & Missouri River water (Jefferson City) & $50 \mu \mathrm{g} \mathrm{L}-1$ & $\mathrm{O}_{3}$ dose $=7.1 \mathrm{mg} \mathrm{L}^{-1}$ & $0.3 \mathrm{mg} \mathrm{L}^{-1} \mathrm{O}_{3}$ at $\left.1.3 \mathrm{~min}\right)(>95 \%)$ & Adams et al., 2002 \\
\hline & Pharmaceutical effluent (Taiwan) & $40 \mathrm{mg} \mathrm{L}^{-1}$ & $\mathrm{O}_{3} / \mathrm{O}_{2}$ mixture, $\mathrm{O}_{3}$ dose $(\mathrm{v} / \mathrm{v})=5.3 \%$, flow $=1.6 \mathrm{~L} \mathrm{~min}^{-1}$. & $(95 \%)$ & Lin et al., 2009b \\
\hline Sulfathiazole & Missouri River water (Jefferson City) & $50 \mu \mathrm{g} \mathrm{L}^{-1}$ & $\mathrm{O}_{3}$ dose $=7.1 \mathrm{mg} \mathrm{L}^{-1}$ & $0.3 \mathrm{mg} \mathrm{L}^{-1} \mathrm{O}_{3}$ at $\left.1.3 \mathrm{~min}\right)(>95 \%)$ & Adams et al., 2002 \\
\hline Sulfamerazine & Missouri River water (Jefferson City) & $50 \mu \mathrm{g} \mathrm{L}^{-1}$ & $\mathrm{O}_{3}$ dose $=7.1 \mathrm{mg} \mathrm{L}^{-1}$ & $0.3 \mathrm{mg} \mathrm{L}^{-1} \mathrm{O}_{3}$ at $\left.1.3 \mathrm{~min}\right)(>95 \%)$ & Adams et al., 2002 \\
\hline Sulfachloropyridazine & Missouri River water (Jefferson City) & $50 \mu \mathrm{g} \mathrm{L} \mathrm{L}^{-1}$ & $\mathrm{O}_{3}$ dose $=7.1 \mathrm{mg} \mathrm{L}^{-1}$ & $0.3 \mathrm{mg} \mathrm{L}^{-1} \mathrm{O}_{3}$ at $\left.1.3 \mathrm{~min}\right)(>95 \%)$ & Adams et al., 2002 \\
\hline \multirow[t]{2}{*}{ Sulfadimethoxine } & Missouri River water (Jefferson City) & $50 \mu \mathrm{g} \mathrm{L}^{-1}$ & $\mathrm{O}_{3}$ dose $=7.1 \mathrm{mg} \mathrm{L}^{-1}$ & $0.3 \mathrm{mg} \mathrm{L}^{-1} \mathrm{O}_{3}$ at $\left.1.3 \mathrm{~min}\right)(>95 \%)$ & Adams et al., 2002 \\
\hline & $\begin{array}{l}\text { Pharmaceutical effluent (Taiwan) } \\
\text { CAS and sand filtration (Tokyo) }\end{array}$ & $\begin{array}{l}40 \mathrm{mg} \mathrm{L}^{-1} \\
492 \mathrm{ng} \mathrm{L}^{-1}\end{array}$ & $\begin{array}{l}\mathrm{O}_{3} / \mathrm{O}_{2} \text { mixture, } \mathrm{O}_{3} \text { dose }(\mathrm{v} / \mathrm{v})=5.3 \% \text {, flow }=1.6 \mathrm{~L} \mathrm{~min}^{-1} \text {. } \\
\mathrm{O}_{3} \text { dose }=3 \mathrm{mg} \mathrm{L} \mathrm{L}^{-1}, \text { Retention time }=27 \mathrm{~min}\end{array}$ & $\begin{array}{l}(96 \%) \\
(93.9 \%)\end{array}$ & $\begin{array}{l}\text { Lin et al., 2009b } \\
\text { Nakada et al., } 2007\end{array}$ \\
\hline \multirow{2}{*}{ Sulfapyridine } & $\begin{array}{l}\text { CAS effluent (Alcala de Henares, } \\
\text { Madrid) }\end{array}$ & $50 \mathrm{ng} \mathrm{L}^{-1}$ & AirSep AS-12 PSA oxygen generation unit & $\mathrm{O}_{3}$ dose $<50 \mu \mathrm{M}(100 \%)$ & Rosal et al., 2010 \\
\hline & $\begin{array}{l}\text { CAS effluent (Regensdorf, } \\
\text { Switzerland) }\end{array}$ & $125 \mathrm{ng} \mathrm{L}^{-1}$ & $\begin{array}{l}\mathrm{O}_{3} \text { dose }=1.6-5.3 \mathrm{mg} \mathrm{L}^{-1}\left(0.36-1.16 \mathrm{~g} \mathrm{~g}^{-1} \mathrm{DOC}\right) \text {, Retention } \\
\text { time }=8-15 \mathrm{~min} \text {, full scale six compartment reactor }\end{array}$ & $\begin{array}{l}\mathrm{O}_{3} \text { dose }=0.40 \mathrm{~g} \mathrm{~g}^{-1} \mathrm{DOC}(98 \%) \\
\mathrm{O}_{3} \text { dose }=0.62 \mathrm{~g} \mathrm{~g}^{-1} \mathrm{DOC}(97 \%) \\
\mathrm{O}_{3} \text { dose }=0.79 \mathrm{~g} \mathrm{~g} \mathrm{~g}^{-1} \mathrm{DOC}(97 \%)\end{array}$ & Hollender et al., 2009 \\
\hline
\end{tabular}




\begin{tabular}{|c|c|c|c|c|c|c|}
\hline Norfloxacin & \multicolumn{2}{|c|}{$\begin{array}{l}\text { CAS effluent (Alcala de Henares, } \\
\text { Madrid) }\end{array}$} & $38 \mathrm{ng} \mathrm{L}^{-1}$ & AirSep AS-12 PSA oxygen generation unit & $\mathrm{O}_{3}$ dose $<90 \mu \mathrm{M}(100 \%)$ & Rosal et al., 2010 \\
\hline \multirow[t]{2}{*}{ Ciprofloxacin } & \multicolumn{2}{|c|}{$\begin{array}{l}\text { Secondary effluent (Kloten-Opfikon, } \\
\text { Switzerland) }\end{array}$} & $1 \mu \mathrm{M}$ & $\begin{array}{l}\text { Batch experiments, } \mathrm{O}_{3} \text { dose }=0.5-5.0 \mathrm{mg} \mathrm{L}^{-1} \\
\text { DOC }=5.3 \mathrm{mg} \mathrm{L}^{-1}\end{array}$ & $\mathrm{O}_{3}$ dose $=3 \mathrm{mg} \mathrm{L}^{-1}(100 \%)$ & Dodd et al., 2006 \\
\hline & \multicolumn{2}{|c|}{$\begin{array}{l}\text { CAS effluent (Alcala de Henares, } \\
\text { Madrid) }\end{array}$} & $522 \mathrm{ng} \mathrm{L}^{-1}$ & AirSep AS-12 PSA oxygen generation unit & $\mathrm{O}_{3}$ dose $<130 \mu \mathrm{M}(100 \%)$ & Rosal et al., 2010 \\
\hline Enrofloxacin & \multicolumn{2}{|c|}{$\begin{array}{l}\text { Secondary effluent (Kloten-Opfikon, } \\
\text { Switzerland) }\end{array}$} & $1 \mu \mathrm{M}$ & $\begin{array}{l}\text { Batch experiments, } \mathrm{O}_{3} \text { dose }=0.5-5.0 \mathrm{mg} \mathrm{L}^{-1} \\
\mathrm{DOC}=5.3 \mathrm{mg} \mathrm{L}^{-1}\end{array}$ & $\mathrm{O}_{3}$ dose $=3 \mathrm{mg} \mathrm{L}^{-1}(100 \%)$ & Dodd et al., 2006 \\
\hline \multicolumn{7}{|l|}{ Trimethoprim } \\
\hline & \multicolumn{2}{|c|}{$\begin{array}{l}\text { Secondary effluent (Kloten-Opfikon, } \\
\text { Switzerland) }\end{array}$} & $1 \mu \mathrm{M}$ & $\begin{array}{l}\text { Batch experiments, } \mathrm{O}_{3} \text { dose }=0.5-5.0 \mathrm{mg} \mathrm{L}^{-1} \\
\mathrm{DOC}=5.3 \mathrm{mg} \mathrm{L}^{-1}\end{array}$ & $\mathrm{O}_{3}$ dose $=3 \mathrm{mg} \mathrm{L}^{-1}(100 \%)$ & Dodd et al., 2006 \\
\hline & \multicolumn{2}{|c|}{ Secondary effluent (German) } & $0.34 \pm 0.04 \mu \mathrm{g} \mathrm{L}^{-1}$ & $\begin{array}{l}\text { Ozonation-UV treatment plant } \\
\mathrm{O}_{3}=100 \mathrm{~g} \mathrm{~h}^{-1}, \mathrm{O}_{3} \text { dose }=5-15 \mathrm{mg} \mathrm{L}^{-1}, 2 \text { diffuser/PVC } \\
\text { bubble columns }\end{array}$ & $\begin{array}{l}\mathrm{O}_{3} \text { dose }: 5-15 \mathrm{mg} \mathrm{L}^{-1} \\
(\geq 85 \%)\end{array}$ & Ternes et al., 2003 \\
\hline & \multicolumn{2}{|c|}{$\begin{array}{l}\text { Secondary wastewater effluent } \\
\text { (Spain) }\end{array}$} & na & Batch experiments, $\mathrm{O}_{3}$ flow $=35 \mathrm{~L} \mathrm{~h}^{-1}, \mathrm{O}_{3}$ dose $=20 \mathrm{mg} \mathrm{L}^{-1}$. & $100 \%$ & Radjenovic et al., 2009b \\
\hline & \multicolumn{2}{|c|}{ Missouri River water (Jefferson City) } & $50 \mu \mathrm{g} \mathrm{L}^{-1}$ & $\mathrm{O}_{3}$ dose $=7.1 \mathrm{mg} \mathrm{L}^{-1}$ & $0.3 \mathrm{mg} \mathrm{L}^{-1} \mathrm{O}_{3}$ at $\left.1.3 \mathrm{~min}\right)(>95 \%)$ & Adams et al., 2002 \\
\hline & \multicolumn{2}{|c|}{ CAS and sand filtration (Tokyo) } & $53.5 \mathrm{ng} \mathrm{L}^{-1}$ & $\mathrm{O}_{3}$ dose $=3 \mathrm{mg} \mathrm{L}^{-1}$, Retention time $=27 \mathrm{~min}$ & $(96 \%)$ & Nakada et al., 2007 \\
\hline & \multicolumn{2}{|c|}{$\begin{array}{l}\text { CAS effluent (Alcala de Henares, } \\
\text { Madrid) }\end{array}$} & $73 \mathrm{ng} \mathrm{L}^{-1}$ & AirSep AS-12 PSA oxygen generation unit & $\mathrm{O}_{3}$ dose $<90 \mu \mathrm{M}(100 \%)$ & Rosal et al., 2010 \\
\hline & \multicolumn{2}{|c|}{ WWTPs in Beijing (China) } & $400 \mathrm{ng} \mathrm{L}^{-1}$ & $\begin{array}{l}\mathrm{O}_{3} \text { dose }=5 \mathrm{mg} \mathrm{L}^{-1} ; \text { Contact time }=15 \mathrm{~min} \\
\text { MF/RO: Spiral-wound crossflow module }\end{array}$ & $(>90 \%)$ & Sui et al., 2010 \\
\hline & \multicolumn{2}{|l|}{$\begin{array}{l}\text { CAS effluent (Regensdorf, } \\
\text { Switzerland) }\end{array}$} & $119 \mathrm{ng} \mathrm{L}^{-1}$ & $\begin{array}{l}\mathrm{O}_{3} \text { dose }=1.6-5.3 \mathrm{mg} \mathrm{L}^{-1}\left(0.36-1.16 \mathrm{~g} \mathrm{~g}^{-1} \mathrm{DOC}\right) \text {, Retention } \\
\text { time }=8-15 \mathrm{~min} \text {, full scale six compartment reactor }\end{array}$ & $\begin{array}{l}\mathrm{O}_{3} \text { dose }=0.40 \mathrm{~g} \mathrm{~g}^{-1} \mathrm{DOC}(97 \%) \\
\mathrm{O}_{3} \text { dose }=0.62 \mathrm{~g} \mathrm{~g}^{-1} \mathrm{DOC}(95 \%) \\
\mathrm{O}_{3} \text { dose }=0.79 \mathrm{~g} \mathrm{~g}^{-1} \mathrm{DOC}(93 \%)\end{array}$ & Hollender et al., 2009 \\
\hline \multicolumn{7}{|l|}{ Tetracyclines } \\
\hline Tetracycline & \multicolumn{2}{|c|}{$\begin{array}{l}\text { Secondary effluent (Kloten-Opfikon, } \\
\text { Switzerland) }\end{array}$} & $1 \mu \mathrm{M}$ & $\begin{array}{l}\text { Batch experiments, } O_{3} \text { dose }=0.5-5.0 \mathrm{mg} \mathrm{L}^{-1} \\
\mathrm{DOC}=5.3 \mathrm{mg} \mathrm{L}^{-1}\end{array}$ & $\mathrm{O}_{3}$ dose $=1.5 \mathrm{mg} \mathrm{L}^{-1}(100 \%)$ & Dodd et al., 2006 \\
\hline \multicolumn{7}{|c|}{ 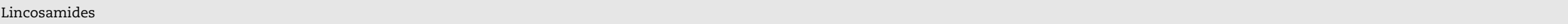 } \\
\hline \multirow[t]{2}{*}{ Lincomycin } & \multicolumn{2}{|c|}{$\begin{array}{l}\text { Secondary effluent (Kloten-Opfikon, } \\
\text { Switzerland) }\end{array}$} & $1 \mu \mathrm{M}$ & $\begin{array}{l}\text { Batch experiments, } \mathrm{O}_{3} \text { dose }=0.5-5.0 \mathrm{mg} \mathrm{L}^{-1} \\
\mathrm{DOC}=5.3 \mathrm{mg} \mathrm{L}^{-1}\end{array}$ & $\mathrm{O}_{3}$ dose $=1 \mathrm{mg} \mathrm{L}^{-1}(70 \%)$ & Dodd et al., 2006 \\
\hline & \multicolumn{2}{|c|}{ CAS effluent (Alcala de Henares, Madrid) } & $12 \mathrm{ng} \mathrm{L}^{-1}$ & AirSep AS-12 PSA oxygen generation unit & $\mathrm{O}_{3}$ dose $<50 \mu \mathrm{M}(100 \%)$ & Rosal et al., 2010 \\
\hline Clindamycin & \multicolumn{2}{|c|}{$\begin{array}{l}\text { CAS effluent (Regensdorf, } \\
\text { Switzerland) }\end{array}$} & $36 \mathrm{ng} \mathrm{L}^{-1}$ & $\begin{array}{l}\mathrm{O}_{3} \text { dose }=1.6-5.3 \mathrm{mg} \mathrm{L}^{-1}\left(0.36-1.16 \mathrm{~g} \mathrm{~g}^{-1} \mathrm{DOC}\right) \text {, Retention } \\
\text { time }=8-15 \mathrm{~min} \text {, full scale six compartment reactor }\end{array}$ & $\begin{array}{l}\mathrm{O}_{3} \text { dose }=0.40 \mathrm{~g} \mathrm{~g}^{-1} \mathrm{DOC}(95 \%) \\
\mathrm{O}_{3} \text { dose }=0.62 \mathrm{~g} \mathrm{~g}^{-1} \mathrm{DOC}(94 \%) \\
\mathrm{O}_{3} \text { dose }=0.79 \mathrm{~g} \mathrm{~g}^{-1} \mathrm{DOC}(91 \%)\end{array}$ & Hollender et al., 2009 \\
\hline $\begin{array}{l}\text { Aminoglycosides } \\
\text { Amikacin }\end{array}$ & \multicolumn{2}{|c|}{$\begin{array}{l}\text { Secondary effluent (Kloten-Opfikon, } \\
\text { Switzerland) }\end{array}$} & $1 \mu \mathrm{M}$ & $\begin{array}{l}\text { Batch experiments, } \mathrm{O}_{3} \text { dose }=0.5-5.0 \mathrm{mg} \mathrm{L}^{-1} \\
\text { DOC }=5.3 \mathrm{mg} \mathrm{L}^{-1}\end{array}$ & $\mathrm{O}_{3}$ dose: $1 \mathrm{mg} \mathrm{L}^{-1}(25 \%)$ & Dodd et al., 2006 \\
\hline \multirow[t]{2}{*}{$\begin{array}{l}\text { Advanced } \\
\text { treatment process } \\
\text { Antibiotic Group }\end{array}$} & \multicolumn{6}{|c|}{ FENTON OXIDATION } \\
\hline & $\begin{array}{c}\text { Type of } \\
\text { wastewater (location) }\end{array}$ & & ntitial & Treatment process & $\begin{array}{l}\text { Results/findings } \\
\text { (Removal efficiency) }\end{array}$ & Reference \\
\hline \multirow[t]{2}{*}{ Amoxicillin } & $\begin{array}{l}\text { Wastewater from plant } \\
\text { manufacturing (China) }\end{array}$ & \multicolumn{2}{|l|}{$\mathrm{Na}$} & \multirow{3}{*}{$\begin{array}{l}\text { Fenton oxidation after extraction (dichloromethane) } \\
{\left[\mathrm{FeSO} \mathrm{C}_{4} .7 \mathrm{H}_{2} \mathrm{O}\right]=10 \mathrm{~g} \mathrm{~L}^{-1} ;\left[\mathrm{H}_{2} \mathrm{O}_{2}\right]=2 \mathrm{~g} \mathrm{~L}^{-1}} \\
\mathrm{TOC}=18925 \mathrm{mg} \mathrm{L} \\
\text { Black light at } 365 \mathrm{~nm} \text { and solar irradiation } \\
{\left[\mathrm{H}_{2} \mathrm{O}_{2}\right]=2.0 \mathrm{mM}} \\
{\left[\mathrm{Ferrioxalate} \text { or Fe}\left(\mathrm{NO}_{3}\right)_{3}\right]=0.20 \mathrm{mM}} \\
\mathrm{pH}=2.5 \\
\mathrm{UV} \text { light }\left(\lambda=253.7 \mathrm{~nm}, 1.73 \times 10^{-4} \text { Einstein }(\mathrm{Ls})^{-1}\right) ; 60 \mathrm{~min} ; \\
\mathrm{pH}=3 ;\left[\mathrm{H}_{2} \mathrm{O}_{2}\right]=20 \mathrm{mM} ;[\mathrm{Fe}(\mathrm{II})]=1 \mathrm{mM} ;[\mathrm{Fe}(\mathrm{III})]=1 \mathrm{mM} \text {. }\end{array}$} & $\begin{array}{l}\mathrm{TOC}=2195.3 \mathrm{mg} \mathrm{L}^{-1}(88.4 \%) \\
\mathrm{COD}=832 \mathrm{mg} \mathrm{L}^{-1}(89.6 \%)\end{array}$ & Zhang et al., 2006 \\
\hline & CAS effluent (Araraquara, Brazil) & $42 \mathrm{mg} \mathrm{L}^{-1}$ & & & $\begin{array}{l}\text { Black light: ( } 89 \% \text { in } 1 \mathrm{~min}) \\
\text { Solar light: ( } 85 \% \text { in } 1 \mathrm{~min}) \\
\text { AMX degradation was not influenced } \\
\text { by the source of the irradiation. }\end{array}$ & Trovó et al., 2008 \\
\hline Penicillin & $\begin{array}{l}\text { Antibiotic formulation effluent } \\
\text { (Turkey) }\end{array}$ & na & & & $\begin{array}{l}\text { COD removal } \\
\text { Photo-Fenton: (56\%) } \\
\text { Photo-Fenton-like: }(66 \%)\end{array}$ & $\begin{array}{l}\text { Arslan Alaton and } \\
\text { Dogruel, } 2004\end{array}$ \\
\hline
\end{tabular}




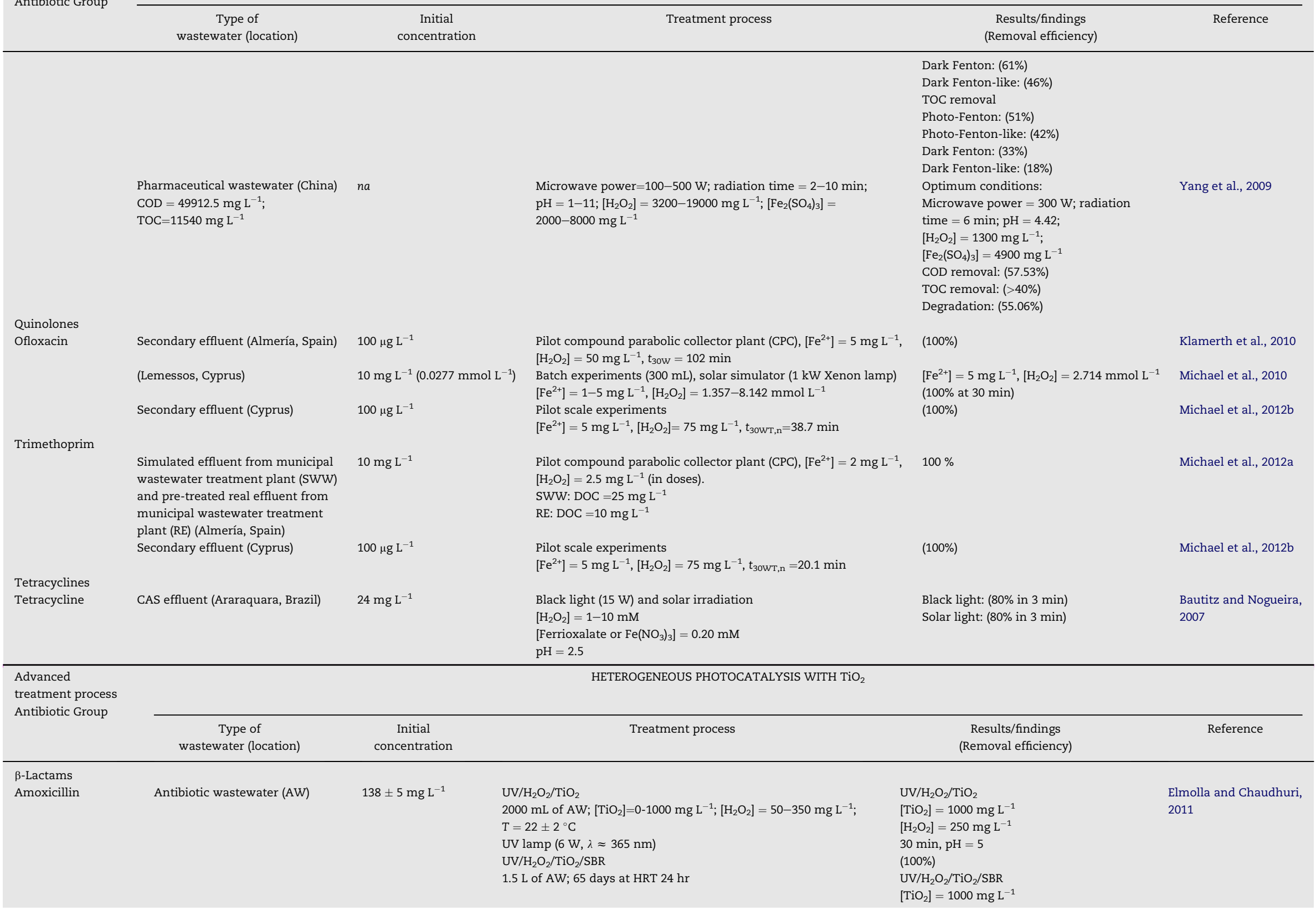




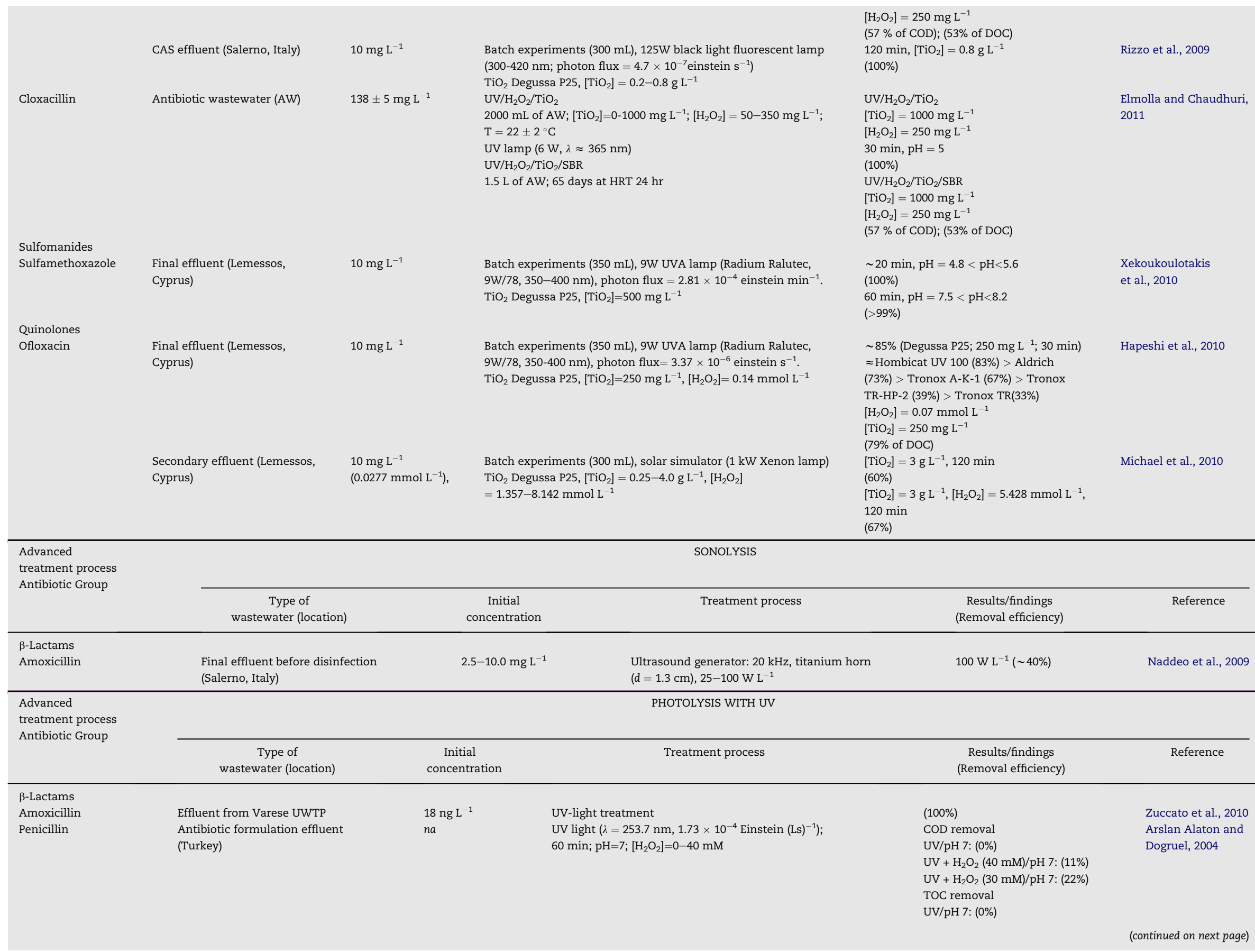


Antibiotic Group

\begin{tabular}{|c|c|c|c|c|c|}
\hline \multirow{2}{*}{ Antibiotic Group } & \multirow[b]{2}{*}{$\begin{array}{c}\text { Type of } \\
\text { wastewater (location) }\end{array}$} & \multirow[b]{2}{*}{$\begin{array}{c}\text { Initial } \\
\text { concentration }\end{array}$} & \multirow{2}{*}{ Treatment process } & \multirow[b]{2}{*}{$\begin{array}{c}\text { Results/findings } \\
\text { (Removal efficiency) }\end{array}$} & \multirow{2}{*}{ Reference } \\
\hline & & & & & \\
\hline & & & & $\begin{array}{l}\mathrm{UV}+\mathrm{H}_{2} \mathrm{O}_{2}(40 \mathrm{mM}) / \mathrm{pH} 7:(10 \%) \\
\mathrm{UV}+\mathrm{H}_{2} \mathrm{O}_{2}(30 \mathrm{mM}) / \mathrm{pH} 7:(6 \%)\end{array}$ & \\
\hline \multicolumn{6}{|c|}{ 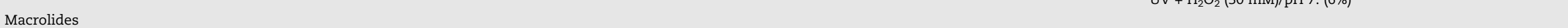 } \\
\hline \multirow[t]{2}{*}{ Clarithromycin } & $\begin{array}{l}\text { Effluent from secondary } \\
\text { sedimentation and sand filter (Japan) }\end{array}$ & $110-656 \mathrm{ng} \mathrm{L}^{-1}$ & $\begin{array}{l}3 \text { UV lamps }(\lambda=254 \mathrm{~nm} \text {; intensity }=1.025 \mathrm{~mW} \mathrm{~cm}-2) ; 3 \\
\text { reactors in series }\left(\mathrm{R}_{1}-\mathrm{R}_{3}\right) \text {; Air flow rate }=0.5 \mathrm{~L} \mathrm{~min}^{-1} \text {; } \\
{\left[\mathrm{H}_{2} \mathrm{O}_{2}\right]=7.8 \mathrm{mg} \mathrm{L}^{-1}}\end{array}$ & $\begin{array}{l}\text { UV: }(24-34 \%) \\
\text { UV }+\mathrm{H}_{2} \mathrm{O}_{2}:(>90 \%)\end{array}$ & Kim et al., 2009 \\
\hline & Effluent from Varese UWTP & $319 \mathrm{ng} \mathrm{L}^{-1}$ & UV-light treatment & $(0 \%)$ & Zuccato et al., 2010 \\
\hline \multirow[t]{3}{*}{ Erythromycin } & Effluent from secondary & $110-656 \mathrm{ng} \mathrm{L}^{-1}$ & 3 UV lamps $\left(\lambda=254 \mathrm{~nm}\right.$; intensity $\left.=1.025 \mathrm{~mW} \mathrm{~cm}^{-2}\right)$ & UV: $(24-34 \%)$ & Kim et al., 2009 \\
\hline & sedimentation and sand filter (Japan) & & $\begin{array}{l}3 \text { reactors in series }\left(\mathrm{R}_{1}-\mathrm{R}_{3}\right) ; \text { Air flow rate }=0.5 \mathrm{~L} \mathrm{~min}^{-1} \text {; } \\
{\left[\mathrm{H}_{2} \mathrm{O}_{2}\right]=7.8 \mathrm{mg} \mathrm{L}^{-1}}\end{array}$ & $\mathrm{UV}+\mathrm{H}_{2} \mathrm{O}_{2}:(>90 \%)$ & \\
\hline & Effluent from Varese UWTP & $12 \mathrm{ng} \mathrm{L}^{-1}$ & UV-light treatment & $(0 \%)$ & Zuccato et al., 2010 \\
\hline Azithromycin & $\begin{array}{l}\text { Effluent from secondary } \\
\text { sedimentation and sand filter (Japan) }\end{array}$ & $110-656 \mathrm{ng} \mathrm{L}^{-1}$ & $\begin{array}{l}3 \text { UV lamps }\left(\lambda=254 \mathrm{~nm} \text {; intensity }=1.025 \mathrm{~mW} \mathrm{~cm}^{-2}\right) \text {; } \\
3 \text { reactors in series }\left(\mathrm{R}_{1}-\mathrm{R}_{3}\right) \text {; Air flow rate }=0.5 \mathrm{~L} \mathrm{~min}^{-1} \text {; } \\
{\left[\mathrm{H}_{2} \mathrm{O}_{2}\right]=7.8 \mathrm{mg} \mathrm{L}^{-1}}\end{array}$ & $\begin{array}{l}\text { UV: }(24-34 \%) \\
\text { UV+ } \mathrm{H}_{2} \mathrm{O}_{2}:(>90 \%)\end{array}$ & Kim et al., 2009 \\
\hline $\begin{array}{l}\text { Spiramycin } \\
\text { Sulfonamides }\end{array}$ & Effluent from Varese UWTP & $603 \mathrm{ng} \mathrm{L}^{-1}$ & UV-light treatment & $(17 \%)$ & Zuccato et al., 2010 \\
\hline \multirow[t]{3}{*}{ Sulfamethoxazole } & $\begin{array}{l}\text { Effluent from Blue Lake WWTP; } \\
\text { Metro WWTP and Lake Josephine } \\
\text { (USA) }\end{array}$ & $1 \mu \mathrm{M}$ & $\begin{array}{l}\text { Photolysis experiments (Suntest CPS + solar simulator } \\
\text { with a UV-Suprax optical filter, } 765 \mathrm{~W} \mathrm{~m}^{-2} \text { ) }\end{array}$ & $(48 \%)$ & Ryan et al., 2011 \\
\hline & $\begin{array}{l}\text { Effluent from secondary } \\
\text { sedimentation and sand filter (Japan) }\end{array}$ & $42-187 \mathrm{ng} \mathrm{L}^{-1}$ & $\begin{array}{l}3 \text { UV lamps }\left(\lambda=254 \mathrm{~nm} \text {; intensity }=1.025 \mathrm{~mW} \mathrm{~cm}^{-2}\right) \text {; } \\
3 \text { reactors in series }\left(\mathrm{R}_{1}-\mathrm{R}_{3}\right) \text {; Air flow rate }=0.5 \mathrm{~L} \mathrm{~min}^{-1} \text {; } \\
{\left[\mathrm{H}_{2} \mathrm{O}_{2}\right]=7.8 \mathrm{mg} \mathrm{L}^{-1}}\end{array}$ & $\begin{array}{l}\text { UV: (89-100\%) } \\
\text { UV }+\mathrm{H}_{2} \mathrm{O}_{2}:(>90 \%)\end{array}$ & Kim et al., 2009 \\
\hline & Effluent from Varese UWTP & $246 \mathrm{ng} \mathrm{L}^{-1}$ & UV-light treatment & $(0 \%)$ & Zuccato et al., 2010 \\
\hline Sulfamethazine & Missouri River water (Jefferson City). & $50 \mu g \mathrm{~L}^{-1}$ & Mercury vapor lamp $(254 \mathrm{~nm})$, UV dose $=0-10000 \mathrm{~mJ} \mathrm{~cm}^{-2}$ & UV dose $=10000 \mathrm{~mJ} \mathrm{~cm}^{-2}(85 \%)$ & Adams et al., 2002 \\
\hline Sulfathiazole & Missouri River water (Jefferson City). & $50 \mu \mathrm{g} \mathrm{L}^{-1}$ & Mercury vapor lamp $(254 \mathrm{~nm})$, UV dose $=0-10000 \mathrm{~mJ} \mathrm{~cm}^{-2}$ & UV dose $=10000 \mathrm{~mJ} \mathrm{~cm}^{-2}(100 \%)$ & Adams et al., 2002 \\
\hline Sulfamerazine & Missouri River water (Jefferson City). & $50 \mu \mathrm{g} \mathrm{L}^{-1}$ & Mercury vapor lamp $(254 \mathrm{~nm})$, UV dose $=0-10000 \mathrm{~mJ} \mathrm{~cm}^{-2}$ & UV dose $=10000 \mathrm{~mJ} \mathrm{~cm}^{-2}(83 \%)$ & Adams et al., 2002 \\
\hline Sulfachlorpyridazine & Missouri River water (Jefferson City). & $50 \mu \mathrm{g} \mathrm{L}^{-1}$ & Mercury vapor lamp $(254 \mathrm{~nm})$, UV dose $=0-10000 \mathrm{~mJ} \mathrm{~cm}^{-2}$ & UV dose: $10000 \mathrm{~mJ} \mathrm{~cm}^{-2}(83 \%)$ & Adams et al., 2002 \\
\hline \multirow[t]{3}{*}{ Sulfadimethoxine } & Missouri River water (Jefferson City). & $50 \mu \mathrm{g} \mathrm{L}^{-1}$ & Mercury vapor lamp $(254 \mathrm{~nm})$, UV dose $=0-10000 \mathrm{~mJ} \mathrm{~cm}^{-2}$ & UV dose: $10000 \mathrm{~mJ} \mathrm{~cm}^{-2}(85 \%)$ & Adams et al., 2002 \\
\hline & Effluent from secondary & $42-187 \mathrm{ng} \mathrm{L}^{-1}$ & 3 UV lamps $\left(\lambda=254 \mathrm{~nm}\right.$; intensity $\left.=1.025 \mathrm{~mW} \mathrm{~cm}^{-2}\right)$ & UV: (89-100\%) & Kim et al., 2009 \\
\hline & sedimentation and sand filter (Japan) & & $\begin{array}{l}3 \text { reactors in series }\left(\mathrm{R}_{1}-\mathrm{R}_{3}\right) ; \text { Air flow rate }=0.5 \mathrm{~L} \mathrm{~min}^{-1} \text {; } \\
{\left[\mathrm{H}_{2} \mathrm{O}_{2}\right]=7.8 \mathrm{mg} \mathrm{L}^{-1}}\end{array}$ & $\mathrm{UV}+\mathrm{H}_{2} \mathrm{O}_{2}:(>90 \%)$ & \\
\hline \multicolumn{6}{|c|}{ 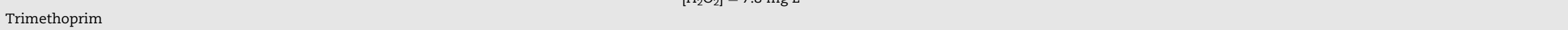 } \\
\hline & $\begin{array}{l}\text { Missouri River water (Jefferson City). } \\
\text { Effluent from Blue Lake WWTP; } \\
\text { Metro WWTP and Lake Josephine } \\
\text { (USA) }\end{array}$ & $\begin{array}{l}50 \mu g \mathrm{~L}^{-1} \\
1 \mu \mathrm{M}\end{array}$ & $\begin{array}{l}\text { Mercury vapor lamp }(254 \mathrm{~nm}) \text {, UV dose }=0-10000 \mathrm{~mJ} \mathrm{~cm}^{-2} \\
\text { Photolysis experiments (Suntest CPS + solar simulator with } \\
\text { a UV-Suprax optical filter, } 765 \mathrm{~W} \mathrm{~m}^{-2} \text { ) }\end{array}$ & $\begin{array}{l}\text { UV dose: } 10000 \mathrm{~mJ} \mathrm{~cm}^{-2}(85 \%) \\
(18 \%)\end{array}$ & $\begin{array}{l}\text { Adams et al., } 2002 \\
\text { Ryan et al., } 2011\end{array}$ \\
\hline & $\begin{array}{l}\text { Tertiary water from Las Vegas, } \\
\text { Nevada (LVNV), Rocky Mountain }\end{array}$ & $38-760 \mathrm{ng} \mathrm{L}^{-1}$ & 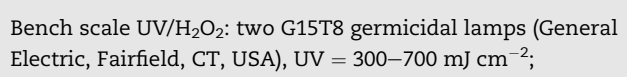 & $\begin{array}{l}\text { UV dose }=300 \mathrm{~mJ} \mathrm{~cm}^{-2} \\
{\left[\mathrm{H}_{2} \mathrm{O}_{2}\right]=20 \mathrm{mg} \mathrm{L}^{-1}(21-67 \%)}\end{array}$ & $\begin{array}{l}\text { Rosario-Ortiz et al., } \\
2010\end{array}$ \\
\hline & Region of Colorado (RMCO) and & & {$\left[\mathrm{H}_{2} \mathrm{O}_{2}\right]=0-20 \mathrm{mg} \mathrm{L}^{-1}$} & $\mathrm{UV}$ dose $=500 \mathrm{~mJ} \mathrm{~cm}^{-2}$ & \\
\hline & Pinellas County, Florida (PCFL). & & & {$\left[\mathrm{H}_{2} \mathrm{O}_{2}\right]=20 \mathrm{mg} \mathrm{L}^{-1}(32-92 \%)$} & \\
\hline & & & & UV dose $=700 \mathrm{~mJ} \mathrm{~cm}^{-2}$ & \\
\hline \multicolumn{6}{|l|}{ Tetracyclines } \\
\hline \multirow[t]{2}{*}{ Tetracycline } & Effluent from secondary & $4-17 \mathrm{ng} \mathrm{L}^{-1}$ & 3 UV lamps $\left(\lambda=254 \mathrm{~nm}\right.$; intensity $\left.=1.025 \mathrm{~mW} \mathrm{~cm}^{-2}\right)$ & UV: (15\%) & Kim et al., 2009 \\
\hline & sedimentation and sand filter (Japan) & & $\begin{array}{l}3 \text { reactors in series }\left(\mathrm{R}_{1}-\mathrm{R}_{3}\right) \text {; Air flow rate }=0.5 \mathrm{~L} \mathrm{~min}^{-1} \text {; } \\
{\left[\mathrm{H}_{2} \mathrm{O}_{2}\right]=7.8 \mathrm{mg} \mathrm{L}^{-1}}\end{array}$ & $\mathrm{UV}+\mathrm{H}_{2} \mathrm{O}_{2}:(>90 \%)$ & \\
\hline Oxytetracycline & Secondary wastewater (Beijing, & $50 \mu \mathrm{M}$ & 11 W low-pressure Hg vapor lamp $(\lambda=254 \mathrm{~nm})$ & UV & Yuan et al., 2011 \\
\hline & China) & & photon flow $=4.5 \times 10^{-5} \mathrm{E} \mathrm{m}^{-2} \mathrm{~s}^{-1} ; \mathrm{UV}$ & UV dose $=30528 \mathrm{~mJ} \mathrm{~cm}^{-2}(100 \%)$ & \\
\hline & & & $\begin{array}{l}\text { dose }=(0-320) \times 10^{2} \mathrm{~mJ} \mathrm{~cm}^{-2} ; 500 \mathrm{~mL} \mathrm{WW} \\
{\left[\mathrm{H}_{2} \mathrm{O}_{2}\right]=1 \mathrm{mM}}\end{array}$ & $\begin{array}{l}\mathrm{UV} / \mathrm{H}_{2} \mathrm{O}_{2} \\
\mathrm{UV} \text { dose }=7632 \mathrm{~mJ} \mathrm{~cm}-2(100 \%)\end{array}$ & \\
\hline
\end{tabular}




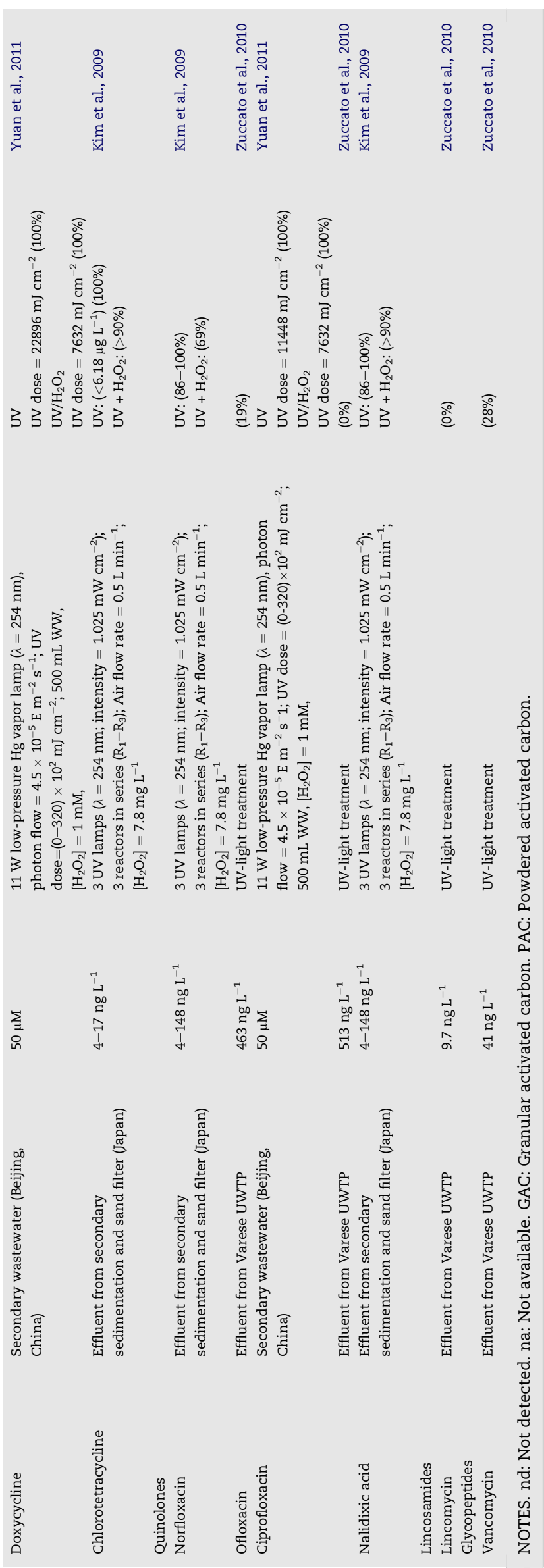

2002; Westerhoff et al., 2005). In a study on hospital wastewater treatment, macrolides, fluoroquinolones, trimethoprim and clindamycin were removed well at PAC dosages of 20-40 $\mathrm{mg} \mathrm{L}^{-1}$, while sulfamethoxazole and metronidazole showed poor removals (McArdell et al., 2011). PAC can also be added directly into the biological reactor, where higher concentrations of carbon are required. Serrano et al. (2011) added $1 \mathrm{~g} \mathrm{~L}^{-1}$ into a sequential membrane bioreactor and found elimination of $42-64 \%$ for erythromycin, $71-97 \%$ for roxitromycin whereas no significant removal was obtained for TMP. Putra et al. (2009) compared the adsorption capacity of activated carbon and bentonite and reported that $94.67 \%$ of amoxicillin was removed from wastewater using activated carbon at a dose as high as $30 \mathrm{~g} \mathrm{~L}^{-1}$.

It should be noted that in the case of the application of the activated carbon adsorption process in wastewater effluents, the natural dissolved organic matter (DOM) in wastewater matrix competes for adsorption sites and decreases the activated carbon capacity for antibiotics and other micropollutants (Snyder et al., 2003).

\subsection{Advanced oxidation processes (AOPs)}

Advanced Oxidation Processes (AOPs) are quite efficient novel methods for water and wastewater treatment (Legrini et al., 1993; Klavarioti et al., 2009; Malato et al., 2009). These processes involve the use and generation of powerful transitory species, principally the hydroxyl radical (HO•) (Goslich et al., 1997; Andreozzi et al., 1999). HO are powerful oxidizing agents leading to oxidation and mineralization of organic matter (Litter, 2005), while this species is characterized by lack of selectivity of attack. This property is of great importance in wastewater treatment because radicals attack the oxidizable part of organic molecules with rates usually in the order of $10^{6}-10^{9} \mathrm{M}^{-1} \mathrm{~s}^{-1}$ (Andreozzi et al., 1999). Several studies have reported the effective AOPs treatment for removal of antibiotics in wastewater effluents (Adams et al., 2002; Arslan Alaton et al., 2004; Saritha et al., 2007; Naddeo et al., 2009; Elmolla and Chaudhuri, 2011). It is worth noting the fact that most studies do not include information on the by-products formed during the application of oxidation or any information related to the antibiotic activity of the byproducts. Therefore, AOPs should be carefully monitored and ecotoxicological investigations should be accompanied to investigate the formation of potentially toxic transformation products (Hollender et al., 2009; Rizzo, 2011). The effectiveness of oxidative processes for degrading antibiotics will be largely determined by the specific water matrix. However, the effects of water matrix quality on antibiotics removal are much less well understood than for other technologies. For example, the presence of natural dissolved organic matter (DOM) can result in the formation of oxidation by-products that may cause water quality to deteriorate beyond its initial state of contamination. Similarly, the presence of nitrates, carbonates and DOM, can interfere with the destruction of the target antibiotic(s) and ultimately reduce the effectiveness of the selected AOP.

The versatility of the AOPs is enhanced by the fact there are different ways of producing hydroxyl radicals, facilitating compliance with the specific treatment requirements. The 
most common AOPs that have been used and evaluated (mainly at a bench scale but many of the processes are being developed at a pilot-scale as well) are: photolysis under ultraviolet (UV) irradiation; combinations of hydrogen peroxide $\left(\mathrm{H}_{2} \mathrm{O}_{2}\right)$, ozone $\left(\mathrm{O}_{3}\right)$ and UV irradiation; homogeneous photocatalysis with Fenton reagent, heterogeneous photocatalysis with semiconductor materials (e.g. $\mathrm{TiO}_{2}$ ) and sonolysis under ultrasound irradiation.

\subsubsection{Ozonation}

Ozone is a powerful oxidant and has been increasingly used for the treatment of wastewater whereas it has been traditionally employed in drinking water treatment (Litter, 2005). Huber et al. (2005) and Hollender et al. (2009) observed that using ozone at a dose of $2 \mathrm{mg} \mathrm{L}^{-1}\left(0.3-0.4 \mathrm{~g} \mathrm{~g}^{-1} \mathrm{DOC}\right)$ more than $80 \%$ of sulfonamides, trimethoprim and macrolides were removed in the effluent of secondary wastewater treatment. Similar results between different wastewater treatment plants are achieved if the dose of ozone per amount of dissolved organic carbon (DOC) is compared. The study by Adams et al. (2002) showed that ozonation removed more than $95 \%$ of several sulfonamides and trimethoprim from river water within $1.3 \mathrm{~min}$ contact time at ozone dose of $7.1 \mathrm{mg} \mathrm{L}^{-1}$. Clindamycin was already removed by $95 \%$ with an ozone dose of $2 \mathrm{mg} \mathrm{L}^{-1}$ (0.40 $\mathrm{g} \mathrm{O}_{3} \mathrm{~g}^{-1} \mathrm{DOC}$ ) (Hollender et al., 2009) and tetracycline by $100 \%$ with an ozone dose of $1.5 \mathrm{mg} \mathrm{L}^{-1}$ (Huber et al., 2005). Balcioglu and Otker (2003) found that up to $80 \%$ of $\beta$-lactams removal from wastewater was observed during ozonation treatment after $60 \mathrm{~min}$ and ozone dose $2.96 \mathrm{~g} \mathrm{~L}^{-1} \mathrm{~h}^{-1}$. In a study of Arslan Alaton et al. (2004) the COD of an antibiotic formulation effluent containing penicillin (COD $\left.=830 \mathrm{mg} \mathrm{L}^{-1}\right)$ was removed by $10-56 \%$ during ozonation process while the addition of small amounts of hydrogen peroxide increased the removal efficiency (83\%). In another study of Arslan Alaton and Dogruel (2004) the COD and TOC of the formulation effluent containing penicillin was removed by $49 \%$ and $52 \%$ respectively under alkaline conditions $(\mathrm{pH}=11)$, whereas the removal efficiency was much lower under acidic conditions $(\mathrm{pH}=3)$ (COD removal $\max =15 \%$; TOC removal $\max =2 \%$ ). Many authors (Balcloglu and Otker, 2003; Arslan Alaton et al., 2004; Andreozzi et al., 2005) suggested that $\mathrm{pH}$ is a critical parameter in the ozonation process and a decrease of $\mathrm{pH}$ usually affects the reaction rate and also the absorption rates of ozone. During wastewater ozonation, many antibiotics, including $\beta$-lactams, sulfonamides, macrolides, quinolones, trimethoprim and tetracyclines, have been shown to be transformed predominantly via direct oxidation by $\mathrm{O}_{3}$ whereas penicillin $\mathrm{G}$, cephalexin and $\mathrm{N}_{4}$-acetylsulfamethoxazole were transformed to a large extent by hydroxyl radicals (Dodd et al., 2006).

Ozone and/or hydroxyl radicals deactivate bactericidal properties of antibiotics by attacking or modulating their pharmaceutically active functional groups, such as N-etheroxime and dimethylamino groups of macrolides (Lange et al., 2006; Dodd et al., 2009), aniline moieties of sulfonamides (Huber et al., 2005), thioether groups of penicillins, unsaturated bonds of cephalosporin and the phenol ring of trimethoprim (Dodd et al., 2009). The high removals (>90\%) by ozonation were achieved for those compounds with electron-rich aromatic systems, such as hydroxyl, amino (e.g. sulfamethoxazoles), acylamino, alkoxy and alkyl aromatic compounds, as well as those compounds with deprotonated amine (e.g. erythromycin, ofloxacin and trimethoprim) and non-aromatic alkene groups since these key structural moieties are highly amendable to oxidative attack (Dickenson et al., 2009).

Research conducted so far demonstrates that ozonation is a promising approach to degrade antibiotics. According to Table 2, ozonation was found to be an effective process for removing $\beta$-lactams, macrolides, sulfonamides and trimethoprim, quinolones, tetracyclines and lincosamides. The energy consumption for upgrading a Swiss municipal wastewater treatment plant with ozonation was evaluated by Hollender et al. (2009). For an ozone dose of $0.6 \mathrm{~g} \mathrm{O}_{3} \mathrm{~g}^{-1} \mathrm{DOC}$ (effluent DOC $\sim 5 \mathrm{~g} \mathrm{~m}^{-3}$ ), $0.035 \mathrm{kWh} \mathrm{m}^{-3}$ wastewater was consumed, which is $12 \%$ of the total energy consumption of a typical nutrient removal plant $\left(0.3 \mathrm{kWh} \mathrm{m}^{-3}\right.$ wastewater). Additionally, $0.01-0.015 \mathrm{kWh} \mathrm{m}^{-3}$ was needed for pure oxygen production. Ozone treatment performance may be enhanced if ozone is combined with UV irradiation, hydrogen peroxide or catalysts (usually iron or copper complexes) (Klavarioti et al., 2009). However, optimal process and operating conditions have yet to be determined for the various water and wastewater types as well as for the different types of antibiotics (Yargeau and Leclair, 2008).

\subsubsection{Fenton oxidation}

Fenton's oxidation is a homogeneous oxidation process and is considered to be a metal-catalyzed oxidation reaction, in which iron acts as the catalyst (Tekin et al., 2006; Saritha et al., 2007). The main disadvantage of the process is the low $\mathrm{pH}$ value required in order to avoid iron precipitation that takes place at higher pH (Melero et al., 2007; Santos et al., 2007).

Trovó et al. (2008) observed that amoxicillin degradation was not influenced by the source of the irradiation during the photoFenton process and the removals of the antibiotic obtained were 89 and $85 \%$ under black light and solar irradiation, respectively. A similar study by Bautitz and Nogueira (2007) showed that tetracycline was removed by $80 \%$ during the photo-Fenton treatment using two types of iron and irradiation. Moreover, in a study by Arslan Alaton and Dogruel (2004) adequate COD and TOC removal rates were achieved during the photo-Fenton and photo-Fenton-like treatment of a formulation effluent containing penicillin. Trimethoprim was completely removed during solar-Fenton process in the study of Michael et al. (2012a) and it was found that the presence of organic carbon and higher salt content in the simulated wastewater and real secondary effluent, led to lower mineralization though per dose of hydrogen peroxide compared to ultrapure water. It is important to highlight that a new approach aimed at performing photoFenton treatment at neutral $\mathrm{pH}$ has been proposed by Klamerth et al. (2010) and De la Cruz et al. (2012). The efficiency of the modified photo-Fenton system is based on the reaction of dissolved organic matter (DOM) present in wastewaters with $\mathrm{Fe}^{2+}$ leading to the formation of soluble iron-complexes. However, contaminants degradation and mineralization tend to be slower at neutral $\mathrm{pH}$ than at $\mathrm{pH}$ 3.0.

Michael et al. (2012b) investigated the application of a solar photo-Fenton system for the degradation of antibiotics at low concentration level $\left(\mu \mathrm{g} \mathrm{L}^{-1}\right)$ in secondary treated domestic effluents at a pilot-scale. The examined antibiotics were ofloxacin and trimethoprim and the pilot treatment plant 
consisted of a compound parabolic collector reactor. The results demonstrated the efficiency of the process in removing enterococci, resistant to these two antibiotics, while the compounds themselves were completely eliminated. The total cost of a full-scale unit for the treatment of $150 \mathrm{~m}^{3}$ day $^{-1}$ of secondary wastewater effluent was estimated to be $0.85 € \mathrm{~m}^{-3}$. This value was found to be in agreement with a previous study of the photo-Fenton process in a pilot-scale set-up (Jordá et al., 2011).

Another approach was taken by Lee et al. (2009) who used ferrate (Fe(VI)) to oxidize micropollutants and remove phosphate by formation of ferric phosphates in wastewater. They showed that Fe(VI) doses higher than $5 \mathrm{mg} \mathrm{Fe} \mathrm{L}^{-1}$ were capable of eliminating sulfamethoxazole and ciprofloxacin by more than $85 \%$. In comparison to ozone, $\mathrm{Fe}(\mathrm{VI})$ was as effective or slightly less effective in terms of micropollutants oxidation, with $\mathrm{Fe}(\mathrm{VI})$ having the benefit of phosphate removal. In general, Fenton process has been extensively used with success for the oxidation of many classes of antibiotics including $\beta$-lactams, quinolones, trimethoprim and tetracyclines.

\subsubsection{Heterogeneous photocatalysis with $\mathrm{TiO}_{2}$}

Heterogeneous photocatalysis by $\mathrm{TiO}_{2}$ semiconductor is achieved usually by the illumination of a suspension of $\mathrm{TiO}_{2}$ in aqueous solution with light energy greater than its bandgap energy. This leads to the formation of high energy electronhole pairs $\left(\mathrm{e}^{-} / \mathrm{h}^{+}\right)$which can migrate on the surface of the catalyst and can either recombine producing thermal energy, or participate in redox reactions with the compounds that are adsorbed on the catalyst's surface (Herrmann et al., 1993; Schiavello, 1993; Robertson, 1996). The valence holes are strong oxidants and are able to oxidize various contaminants, as well as water, resulting in the formation of $\mathrm{HO}$. while the conduction band electrons are good reductants reducing the dissolved oxygen to $\mathrm{O}_{2}{ }^{--}$(Munter, 2001).

The study of Elmolla and Chaudhuri (2011) examined the feasibility of using combined $\mathrm{TiO}_{2}$ photocatalysis $\left(\mathrm{UV} / \mathrm{TiO}_{2} /\right.$ $\mathrm{H}_{2} \mathrm{O}_{2}$ ) and sequencing batch biological reactor (SBR) process for the treatment of an antibiotic wastewater containing amoxicillin and cloxacillin. The complete removal of these compounds was observed at $\mathrm{TiO}_{2}$ and $\mathrm{H}_{2} \mathrm{O}_{2}$ doses of 1000 and $250 \mathrm{mg} \mathrm{L}^{-1}$, respectively. Amoxicillin was also completely removed from urban wastewater treatment plant effluent using $\left[\mathrm{TiO}_{2}\right]=0.8 \mathrm{~g} \mathrm{~L}^{-1}$ after $120 \mathrm{~min}$ of treatment as reported by Rizzo et al. (2009). Ofloxacin in wastewater samples was removed by $60 \%$ using $\left[\mathrm{TiO}_{2}\right]=3 \mathrm{~g} \mathrm{~L}^{-1}$ (Michael et al., 2010) while Hapeshi et al. (2010) reported that the DOC of a solution contained ofloxacin at $10 \mathrm{mg} \mathrm{L}^{-1}$ was reduced by $79 \%$ after $120 \mathrm{~min}$ of photocatalytic treatment using $\left[\mathrm{TiO}_{2}\right]=250 \mathrm{mg} \mathrm{L}^{-1}$ and $\left[\mathrm{H}_{2} \mathrm{O}_{2}\right]=0.07 \mathrm{mmol} \mathrm{L}^{-1}$.

Besides some drawbacks of the heterogeneous photocatalysis (e.g. the rather small quantum yield of the process; the relatively narrow light-response range of $\mathrm{TiO}_{2}$; the need of post-separation and recovery of the catalyst particles from the reaction mixture in aqueous slurry systems), $\mathrm{TiO}_{2}$ seems to possess some interesting features, such as high chemical stability in a wide $\mathrm{pH}$ range, strong resistance to chemical breakdown and photocorrosion, commercial availability and good performance. The catalyst is also cheap and can be reused (Andreozzi et al., 1999; Malato et al., 2009). The properties of antibiotics to be treated such as $p K_{a}$ and molecular structure will determine not only the efficiency of their photocatalytic degradation but also the mechanisms of the oxidation products formation (i.e. contribution of $\mathrm{HO}$ - radical and valence band holes oxidation pathway).

\subsubsection{Sonolysis}

Ultrasound irradiation or sonolysis is a relatively new process in water and wastewater treatment and therefore, has unsurprisingly received less attention than other AOPs. This is also reflected by the small number of publications concerning the treatment of pharmaceutical compounds. Ultrasound enhances chemical and physical changes in a liquid medium through the generation and subsequent destruction of cavitation bubbles. These bubbles grow over a period of a few cycles to an equilibrium size for the particular frequency applied. It is the fate of these bubbles when they collapse in succeeding compression cycles that generates the energy for chemical and mechanical effects (Parsons, 2004). The sonochemical degradation in aqueous phase involves several reaction pathways and zones such as pyrolysis inside the bubble and/or at the bubble-liquid interface and hydroxyl radical-mediated reactions at the bubble-liquid interface and/or in the liquid bulk. Pyrolytic reactions inside or near the bubble as well as solution radical chemistry are the two major pathways of sonochemical degradation (Emery et al., 2005).

According to the authors' best knowledge, only one paper is available up to now in the literature on the applicability of sonolysis to remove antibiotics from wastewater effluents. Naddeo et al. (2009) evaluated the ultrasonic process on the degradation of amoxicillin spiked in urban wastewater effluent. It was found that the amoxicillin conversion was enhanced at increased applied power densities, acidic conditions and in the presence of dissolved air and the maximum removal observed was $40 \%$.

It is important to note that there is limited literature (Hernández-Sancho et al., 2010; Mahamuni and Adewuyi, 2010; Jordá et al., 2011; Hollender et al., 2009; Michael et al., 2012b) dealing with advanced wastewater treatment process economics although this aspect is a very important issue.

\subsection{Effect of disinfection on antibiotics removal}

\subsubsection{Chlorination}

Limited studies have focused on the removal of antibiotics during wastewater treatment with chlorine. Chlorination is by far the most common method of wastewater disinfection and is used worldwide for the disinfection of pathogens before discharge into receiving streams, rivers or oceans. From the chlorinated species, hypochlorite $\left(\mathrm{ClO}^{-}\right)$has the highest standard oxidation potential $\left(E_{0}=1.48 \mathrm{~V}\right)$, followed by chlorine gas $\left(E_{0}=1.36 \mathrm{~V}\right)$ and chlorine dioxide $\left(E_{0}=0.95 \mathrm{~V}\right)$ (Homem and Santos, 2011). The two major disadvantages of using chlorine based disinfectants are (i) the safety hazards associated with storage, transportation and handling of chlorine, and (ii) the potential formation of disinfection byproducts.

The effective removal of antibiotics by chlorination from wastewater requires sufficient free chlorine concentration and contact time. For example, cephalexin which was 
removed by $91 \%$ in activated sludge treatment at the Stanley WWTP was further removed in the following disinfection process by $99 \%$, resulting in a total removal of $100 \%$ in the Stanley WWTP whole treatment process (Li and Zhang, 2011). Li and Zhang (2011) also reported that during chlorine disinfection process roxithromycin was eliminated by a further $18 \%$ (total removal $53 \%$ ), erythromycin $-\mathrm{H}_{2} \mathrm{O}$ by $24 \%$ (total removal $43 \%$ ), sulfamethoxazole by $27 \%$ (total removal $73 \%$ ) and trimethoprim by $40 \%$ (total removal $65 \%$ ).

\subsubsection{Ultraviolet irradiation}

Ultraviolet (UV) disinfection is increasingly finding applications in UWTPs. Photolytic degradation can be either direct or indirect. In direct photolysis, the target contaminant (in this case the antibiotic compound) absorbs a solar photon, which leads to a break-up of the molecule. In an indirect photolysis mechanism, naturally occurring molecules in the system such as dissolved organic matter (DOM) act as sensitizing species which generates strong reactive agents e.g. singlet oxygen $\left({ }^{1} \mathrm{O}_{2}\right)$, hydroxyl radicals (HO) or alkyl peroxyl radicals ( $\circ \mathrm{OOR})$ and hydrate electrons under solar radiation (Arnold and McNeill, 2007; Fatta-Kassinos et al., 2011b). Generally, the degradation of a compound by UV irradiation is affected by the UV energy absorption and the quantum yield of the compound. UV energy absorption is expressed as molar extinction coefficient, which is a measure of how strongly a chemical species absorbs light at a given wavelength that can be used for its degradation (Kim et al., 2009).

Ultraviolet irradiation has been widely used for the treatment of waters and wastewaters worldwide. Several studies have reported the effective treatment of UV irradiation for removal of antibiotics in wastewater effluents (Adams et al., 2002; Ryan et al., 2011; Yuan et al., 2011). It has been recently reported that at high UV doses of nearly $11,000-30,000 \mathrm{~mJ} \mathrm{~cm}{ }^{2}$, an almost complete removal of tetracyclines and ciprofloxacin was achieved (Yuan et al., 2011). Kim et al. (2009) reported that sulfonamides (sulfamethoxazole and sulfadimethoxine) and quinolones (norfloxacin and nalidixic acid) showed high removal efficiency in the range of $86-100 \%$ during the UV process. In contrast to this, macrolides (clarithromycin, erythromycin and azithromycin) were removed by $24-34 \%$. Among tetracyclines, chlorotetracycline concentration decreased to less than limit of detection during the UV process while only $15 \%$ removal efficiency was achieved for tetracycline. This can be explained by the low molar extinction coefficient of tetracycline $\left(4108 \mathrm{M}^{-1} \mathrm{~cm}^{-1}\right)$ comparing to that of chlorotetracycline $\left(18,868 \mathrm{M}^{-1} \mathrm{~cm}^{-1}\right)$.

Another study of photolysis was conducted by Arslan Alaton and Dogruel (2004) in which penicillin in the form of formulation effluent with total COD $=1555 \mathrm{mg} \mathrm{L}^{-1}$ was treated under UV irradiation or UV combined with $\mathrm{H}_{2} \mathrm{O}_{2}$. In this study, the removal efficiency was very low compared to the others described above (COD removal $\max =22 \%$ and TOC removal $\max =10 \%$ with 30 and $40 \mathrm{mM}$ of peroxide respectively) and this may be attributed to the complexity of the formulation effluent (high COD and TOC values). Zuccato et al. (2010) also reported complete elimination of amoxicillin in Varese WWTP with UV-light treatment. The addition of $\mathrm{H}_{2} \mathrm{O}_{2}$ to UV has proven to be more efficient in removing antibiotics than UV alone, and lower fluence doses need to be applied for the same removal (Kim et al., 2009; Rosario-Ortiz et al., 2010; Yuan et al., 2011).

Many of the antibiotics have aromatic rings, structural moieties (such as phenol and nitro groups) heteroatoms, and other functional chromophore groups that can either absorb solar radiation or react with photogenerated transient species in natural waters (e.g. photo excited natural organic matterNOM) (Fatta-Kassinos et al., 2011b). The organic matter (DOC, COD), UV dose, contact time and the chemical structure of the compound are important factors governing the removal efficiency of antibiotics during direct photolysis. This technology is only applicable to wastewater containing photosensitive compounds and waters with low COD concentrations (e.g. river, drinking waters) (Homem and Santos, 2011). Furthermore, wastewater effluents have different organic compounds that may either inhibit or enhance the process by scavenging or generating oxidant species (humic and inorganic substances like dissolved metals) (Jiao et al., 2008). Generally, photolysis has proved to be less effective in degrading antibiotics in wastewater effluents and more energy demanding (Katsoyiannis et al., 2011) than e.g. ozonation.

\section{Concluding remarks and future trends}

The conventional sewage treatment facilities were never designed to deal with pharmaceutical compounds. Due to their highly variable physicochemical properties (chemical structure, solubility, octanol/water partition coefficient) as well as the operational conditions of the biological process, the efficiencies by which pharmaceuticals are removed vary substantially. Unfortunately, the lack of data concerning the biological treatment processes does not allow comparison among the various studies conducted, and there are only few studies, which comprehensively and systematically investigated operating conditions of the biological treatment. In general, MBR systems have been reported to be equal to or slightly more effective in removing some antibiotics compared to CAS treatment systems (Le-Minh et al., 2010); MBR is more expensive, but provides a more hygienic effluent due to the filtration. As a consequence of the inability of the most commonly applied biological treatments to sufficiently remove antibiotics, the latter are regarded as pseudopersistent contaminants due to their continual introduction into the environment and permanent presence.

Advanced treatment, downstream of conventional biological process, can significantly improve antibiotics removal before effluent disposal. Although capital and operational costs of an advanced treatment increase the costs of conventional process, further improvement of micropollutants and other antibiotics removal, in line with possible stringent regulations might be difficult to achieve without advanced treatment. The installation of treatment techniques to remove antibiotics in wastewaters should also be flexible and allow their implementation not only in UWTPs, but also at important source points such as hospitals and the pharmaceutical industry.

More comprehensive studies are required to thoroughly understand the behavior of antibiotics under both conventional sewage treatment and advanced treatment processes and to gain more knowledge on the elimination processes 
within the UWTPs including sorption onto sewage sludge. Furthermore, studies should provide all basic treatment plant operational parameters since these are essential for later comparison or assessments.

It is important to underline also the fact that only little information is currently available with regard to transformation products formed in the environment or UWTPs and during oxidative treatment. Future research should include a dedicated focus on the potential formation of pharmacologically active or more toxic products during treatment processes. Additionaly, it is necessary to conduct research on the occurrence, fate and removal of humans' metabolites in UWTPs. Most antibiotics and their metabolites are excreted by humans after administration and therefore discharged to the municipal sewage; however, only little is known about their biodegradability in the aquatic environments.

From a practical point of view, it is necessary to study process integration to maximize the treatment performance in removing antibiotics and for disinfection including those that can use renewable energy resources to power the processes. Moreover, both environmental and economic assessments are considered necessary in the framework of industrial scale applications for the removal of antibiotic residues from wastewater.

Finally, evaluation of the negative impacts (i.e. antibiotic bacteria and resistance genes evolution, toxicity on organisms and plants) caused by the presence of antibiotics in the environment is considered as a necessity in order to reduce the risk for humans.

\section{Acknowledgments}

Nireas-International Water Research Center is a project cofunded by the European Regional Development Fund and the Republic of Cyprus through the Research Promotion Foundation (Strategic Infrastructure Project NEAYחO $\Delta \mathrm{OMH} / \mathrm{\Sigma TPATH} /$ 0308/09), and the University of Cyprus. The authors would like to thank EU for the support provided through Cost Action "TD0803: Detecting evolutionary hot spots of antibiotic resistances in Europe (DARE)". Luigi Rizzo wishes to thank University of Salerno for funding the project "Effect of solar photolysis on antibiotic degradation, antibiotic resistant bacteria inactivation as well as on their capacity to develop antibiotic resistance in surface water", Ex 60\%, anno 2011.

Christophe Merlin and Christophe Dagot wish to thank the ANR national program ECOTECH, the EU interreg PILLS Program, and the Zone Atelier Moselle (ZAM) for supporting investigations regarding parameters affecting antibiotic resistance gene transfer in environmental matrices.

\section{Appendix A}

\section{Supporting Information}

\begin{tabular}{|c|c|}
\hline Reference & Location \\
\hline Abegglen et al., 2009 & Switzerland \\
\hline Batt et al., 2007 & $\begin{array}{l}\text { Erie County (New York) } \\
\text { (Amherst, East Aurora, Holland, } \\
\text { Lackawanaa). }\end{array}$ \\
\hline Bendz et al., 2005 & Kallby (Sweden) \\
\hline Brown et al., 2006 & $\begin{array}{l}\text { Rio Grande (Colorado) (Magdalena; } \\
\text { Hagerman; Socorro; Portales; Santa Fe; } \\
\text { Albuquerque) }\end{array}$ \\
\hline Carballa et al., 2004 & Galicia (Spain) \\
\hline Castiglioni et al., 2008 & Varese Olona (Italy) \\
\hline Cha et al., 2006 & Fort Collins (Colorado) \\
\hline Choi et al., 2007 & Korea \\
\hline Clara et al., 2005 & South-East of Austria \\
\hline Costanzo et al., 2005 & Brisbane (Australia) \\
\hline
\end{tabular}

CAS and MBR (aerobic or anoxic).

$\mathrm{SRT}_{1}>150$ days; $\mathrm{HRT}_{1}=6.3$ days; $\mathrm{SRT}_{2}>100$ days;

$\mathrm{HRT}_{2}=3.4$ days

Amherst: Primary treatment; Secondary treatment

(Stage 1: CAS; Stage 2: nitrification); Tertiary treatment

(Sand filtration); Chlorination.

East Aurora: No Primary treatment; Secondary

treatment (Extended aeration; Ferrous chloride addition);

Tertiary treatment (Sand filtration); UV radiation.

Holland: Primary treatment; Secondary treatment

(Rotating biological contactors); Tertiary treatment (Sand filtration); UV radiation.

Lackawana: Primary treatment; Secondary treatment

(Pure oxygen activated sludge); Chlorination.

Primary treatment (Bar screening; Grit removal; Primary

clarification); CAS; Chemical phosphorous removal;

Final sedimentation.

CAS

Pre-treatment (coarse screening, bar racks, fine screening and aerated chambers for grit and fat removal); Primary treatment; CAS; Sedimentation tank. na Pretreatment; Primary treatment; CAS; Chlorination. CAS Primary treatment (screen; grit chamber); CAS. MBR pilot plant (UF, cross flow); SRT $=10-55$ days. $\mathrm{Na}$ 
Supporting Information - (continued)

Reference

Dolar et al., 2012

Castell-Platja d'Aro (Spain)

Fatta et al., 2010

Cyprus

Göbel et al., 2005; Göbel et al., 2007

Golet et al., 2002

Golet et al., 2003

Gros et al., 2006

Gulkowska et al., 2008

Jelic et al., 2011

Joss et al., 2005

Karthikeyan and Meyer, 2006 Kasprzyk-Hordern et al., 2009 Kovalova et al., 2012
Switzerland (Kloten-Opfikon (UWTP-K); Altenrhein (UWTP-A))

Glatt Valley Watershed (Switzerland) Zurich-Werdholzli (Switzerland)

\section{Croatia}

Hong Kong and Shenzhen (China)

(Wan Chai, Shatin, Tai Po,

Stonecutters Island, Nan Shan)

Catalonia (Spain)

Switzerland (Kloten-Opfikon (UWTP-K); Altenrhein (UWTP-A))

Wisconsin (USA)

South Wales (England)

Switzerland
Li and Zhang, 2011

Li et al., 2009
Hong Kong (Stanley and Shatin)

Hong Kong (Stanley and Shatin)
Main treatment steps

MBR-RO pilot plant ( $8 \mathrm{~m}^{2}$ of flat sheet membranes; pore size of $0.4 \mu \mathrm{m}$ ): HRT $=12.5 \mathrm{~h}$; SRT $=45$ days RO system: one pressure vessel housing, a double element (Ropur membranes TR70-4021-HF) with an automatic cleaning system; high flow, crosslinked, aromatic polyamide, negative charge spiral wound module.

UWTP I: Primary treatment; Secondary treatment (oxidation ditches, secondary settlement); Tertiary treatment (sand filtration); Chlorination.

UWTP II: Primary treatment; CAS; Tertiary treatment (sand filtration); Chlorination.

UWTP III: Primary treatment; Secondary treatment (phosphorus biological removal, nitrification and denitrification, secondary clarifiers); Tertiary treatment (sand filtration); Chlorination.

Primary treatment (screen, aerated grit-removal tank, primary clarifier); Secondary treatment (UWTP-K: CAS; UWTP-A: CAS and FBR); Tertiary treatment (sand filtration).MBR (in UWTP-K): operated in parallel to CAS (HRT $=13 \mathrm{~h}$ ).

Three different membrane filtration units: MF plate membrane module $(0.4 \mu \mathrm{m})$; UF hollow-fibre modules $(0.1 \mu \mathrm{m})$; UF hollow-fibre modules $(0.04 \mu \mathrm{m}) . \mathrm{SRT}_{1}=16$; $\mathrm{SRT}_{2}=33$ days; $\mathrm{SRT}_{3}=60-80$ days

FBR (in UWTP-A): 8 Biostyr up-flow cells, $3.6 \mathrm{~mm}$ Styrofoam beads as biofilm support CAS

Primary treatment (screens; combined grid; fat removal tank; primary clarification); CAS (SRT = 11days); Denitrification; Flocculation-filtration.

CAS

Wan Chai: Primary treatment

Shatin: Primary treatment (Screening; Settlement of grit particles; Primary sedimentation); CAS

Tai Po: Primary treatment (Removal of solids and grit; Primary sedimentation); Biological treatment; Stonecutters Island: Chemically enhanced primary treatment

Nan Shan: Primary treatment

UWTP $_{1}$ : Pre-treatment, Primary treatment; Secondary treatment (anoxic/aerobic and secondary settling, coagulation/flocculation/lamella clarifier); Tertiary treatment (microfiltration); Chlorination.

UWTP $_{2}$ : Pre-treatment, Primary treatment, CAS $\mathrm{UWTP}_{3}$ : Primary treatment; Secondary biological treatment (nitrogen and phosphorus removal). Primary treatment (screen, aerated grit-removal tank, primary clarifier); Secondary treatment (UWTP-K: CAS; UWTP-A: CAS and a FBR); Tertiary treatment (sand filtration). $\mathrm{SRT}_{1}=16-33$ days; $\mathrm{SRT}_{2}=60-80$ days

CAS

Cilfynydd: Trickling filter beds; Coslech: CAS

Pilot-scale MBR: average influent of $1.2 \mathrm{~m}^{3}$ day $^{-1}$ pumped directly from the hospital sewer collection system. Sludge concentration $=2 \mathrm{~g} \mathrm{~L}^{-1}$, SRT $=30-50$ days, $\mathrm{T}_{\text {average }}=29^{\circ} \mathrm{C}, \mathrm{pH}=7.8$, conductivity $=1100 \mu \mathrm{S} \mathrm{cm}^{-1}$. Submerged ultrafiltration flat sheet membrane plates (Huber MembraneClearBox, PP carrier, PES membrane, $7 \mathrm{~m}^{3}, 15-30 \mathrm{~L} \cdot \mathrm{m}^{-2} \cdot \mathrm{h}^{-1}, 38 \mathrm{~nm}$ pore size, $150 \mathrm{kDa}$ ). Shatin (Anoxic-Aerobic CAS); Stanley (Anoxic-Aerobic CAS and Chlorination)

na 
Supporting Information - (continued)

Reference

Lin et al., 2009

Taipei (Taiwan)

Lindberg et al., 2005

Löffler and Ternes, 2003

Loganathan et al., 2009

McArdell et al., 2003

Pailler et al., 2009

Peng et al., 2006

Radjenovic et al., 2009b

Reif et al., 2008

Renew and Huang, 2004

Roberts and Thomas, 2006

Sahar et al., 2010

Spongberg and Witter, 2008

Sui et al., 2010

Tambosi et al., 2010

Ternes et al., 2007

Watkinson et al., 2007

Watkinson et al., 2009

Xia et al., 2012

Germany

Terrassa (Spain)

Spain

Howdon (UK)

Tel-Aviv (Israel)

Beijing (China)

China
Sweden (Stockholm; Gothenburg; Umeå; Kalmar; and Floda)

South-western Kentucky

Switzerland (Kloten-Opfikon; Zurich-Werdhoelzli; and Duebendorf Beggen (Luxemburg)

Guangzhou (China)

California (UWTP I) and Arizona (UWTP II) (Georgia)

Northwest Ohio (USA)

Aachen (Germany)

Braunschweig (Germany)

Brisbane (Australia)

South-East Queensland (Australia)
Gao Beidian (Beijing, China)
Main treatment steps

UWTP $_{1}$ : Screening and sedimentation; CAS; UV.

$\mathrm{UWTP}_{2}$ : Grit removal and screening and sedimentation, deep shaft and step aeration and sedimentation; Chlorination.

$\mathrm{UWTP}_{3}$ : Screening; Trickling filter and sedimentation; Chlorination.

$\mathrm{UWTP}_{4}$ : Screening and grit removal and sedimentation; CAS and sedimentation; Chlorination.

Chemical removal of phosphorus; Primary clarification; CAS with nitrogen removal (except Umeå and Floda); Secondary clarification.

Hospital wastewater; $0.45-\mu \mathrm{m}$ polystyrene filters Large grit removal; Returned Activated Sludge; Post-Clarifier/Pre-Chlorination; Oxidation ditch; Post-Chlorination

Primary treatment; Secondary treatment; Tertiary treatment (sand filtration)

na

GZ-UWTP ${ }_{1}$ : Sedimentation; CAS; Filtration.

GZ-UWTP $_{2}$ : CAS; Filtration; Chlorination.

Two pilot-scale MBRs were operating in parallel with

CAS (SRT $>60$ days): Hollow-fibre ultra-filtration membranes (HF-UF) (HRT=7.2 h); flat-sheet micro-filtration membranes (FS-MF) (HRT = $15 \mathrm{~h})$. MBR: Zenon ZW-10 submerged hollow fibre membrane module (average pore size $=0.04 \mu \mathrm{m}$; nominal surface area of $0.9 \mathrm{~m}^{2}$ ), SRT $=44-72$ days. Primary treatment (screening and sedimentation); CAS; Tertiary treatment; Disinfection (UWTP I: chlorination; UWTP II: UV).

Primary treatment (coarse screening; preliminary clarification); CAS and trickling filter system; High-pressure $254 \mathrm{~nm}$ UV disinfection.

MBR/RO plant: Two Zenon ZeeWeed 500 UF immersed hollow fiber membranes (total area $=2 \mathrm{~m}^{2}$ ); RO membrane Filmtec TW30 25-40 (surface area $=2.7 \mathrm{~m}^{2}$ ).

CAS-UF/RO plant: UF (24 modules, $1024 \mathrm{~m}^{2}$, ZeeWeed-1000 immersed hollow fibers); RO membrane Filmtec BW30-400 (total area $=1295 \mathrm{~m}^{2}$ ).

SRT $>40$ days

na

Primary treatment; Secondary biological treatment (A and D: anaerobic/anoxic/oxic $\left[\mathrm{A}^{2} / \mathrm{O}\right]$ ) CAS; B: anoxic/oxic [A/O]) CAS; C: Oxidation ditch [OD].

MBR pilot plant receives effluent from the pre-settling tank.

MBR-15 (V = $260 \mathrm{~L}):$ SRT $=15$ days; HRT $=6 \mathrm{~h}$

MBR-30 ( $V=240 \mathrm{~L}):$ SRT $=30$ days; HRT $=13 \mathrm{~h}$

Hollow-fiber ultrafiltration (UF) membranes (PURON,

KMS Germany): area $=1.43 \mathrm{~m}^{2}$; pore size $=0.04 \mu \mathrm{m}$;

polyethersulfone (PES).

Primary treatment (screen; aerated grid-removal tank; primary clarifier); CAS; Phosphate removal; Nitrification-denitrification.

Primary treatment; CAS (SRT $=12.5$ days)

na

Lab-scale A/O-MBR (6 L): (i) anoxic unit (AN, 2 L) and (ii) aerobic unit (AO, $4 \mathrm{~L}$ ). A hydrophilic polyvinylidene fluoride (PVDF) hollow fiber membrane module was used in the AO unit (pore size $=0.02 \mu \mathrm{m}$; effective filtration area $=0.1 \mathrm{~m}^{2}$ ).

SRT $=3-60$ days; HRT $=6-24 \mathrm{~h}$

Primary treatment; Secondary treatment processes 
Supporting Information - (continued)

\begin{tabular}{|c|c|c|}
\hline Reference & Location & Main treatment steps \\
\hline Xu et al., 2007 & $\begin{array}{l}\text { Guangzhou and Hong Kong } \\
\text { (South China) } \\
\text { (Kaifaqu, Liede, New Territory, Kowloon) }\end{array}$ & $\begin{array}{l}\text { Kaifaqu: Primary treatment; CAS; Chlorination. } \\
\text { Liede: Primary treatment; Oxidation ditch; UV. } \\
\text { New Territory: Primary treatment; CAS. } \\
\text { Kowloon: Primary treatment; Chemically enhanced; } \\
\text { Chlorination. }\end{array}$ \\
\hline Yang and Carlson, 2004 & Northern Colorado (USA) & $\mathrm{Na}$ \\
\hline Yang et al., 2005 & Fort Collins (Colorado) & $\begin{array}{l}\text { Pretreatment; Primary treatment; Secondary treatment } \\
\text { (secondary clarification); Chlorination. }\end{array}$ \\
\hline Yu et al., 2009 & Taiwan & $\begin{array}{l}\text { Extended sludge age biological technology }(\mathrm{HRT}=12 \mathrm{~h} \text {; } \\
\left.\text { SRT }>200 \text { days; } \mathrm{MLSS}=16000 \mathrm{mg} \mathrm{L}^{-1}\right)\end{array}$ \\
\hline Zorita et al., 2009 & Kristianstad (Sweden) $\left(\mathrm{UWTP}_{1}-\mathrm{UWTP}_{5}\right)$ & $\begin{array}{l}\text { Primary treatment (screens; grit-aerated chamber); CAS; } \\
\text { Chemical removal; Tertiary treatment (Sand filtration). }\end{array}$ \\
\hline Zuccato et al., 2010 & $\begin{array}{l}\text { Italy and Switzerland } \\
\text { (Milan, Varese, Como, Lugano) }\end{array}$ & $\begin{array}{l}\text { Pre-treatment; Primary treatment (primary settling); CAS; } \\
\text { UV-light treatment (Varese). }\end{array}$ \\
\hline
\end{tabular}

\section{R E F E R E N C E S}

Abegglen, C., Joss, A., McArdell, C.S., Fink, G., Schlüsener, M.P., Ternes, T.A., Siegrist, H., 2009. The fate of selected micropollutants in a single-house MBR. Water Research 43, 2036-2046.

Adams, C., Asce, M., Wang, Y., Loftin, K., Meyer, M., 2002. Removal of antibiotics from surface and distilled water in conventional water treatment processes. Journal of Environmental Engineering 128, 253-260.

Aksu, Z., Tunç, O., 2005. Application of biosorption for penicillin G removal: comparison with activated carbon. Process Biochemistry 40, 831-847.

Alturki, A.A., Tadkaew, N., McDonald, J.A., Khan, S.J., Price, W.E., Nghiem, L.D., 2010. Combining MBR and NF/RO membrane filtration for the removal of trace organics in indirect potable water reuse applications. Journal of Membrane Science 365, 206-215.

Andreozzi, R., Caprio, V., Insola, A., Marotta, R., 1999. Advanced oxidation processes (AOP) for water purification and recovery. Catalysis Today 53, 51-59.

Andreozzi, R., Canterino, M., Marotta, R., Paxeus, N., 2005. Antibiotic removal from wastewaters: the ozonation of amoxicillin. Journal of Hazardous Materials 122, 243-250.

Arnold, W.A., McNeill, K., 2007. In: Petrović, M., Barceló, D. (Eds.), Transformation of Pharmaceuticals in the Environment: Photolysis and Other Abiotic Processes. Comprehensive Analytical Chemistry 50, pp. 361-385. Chapter 3.2.

Arslan Alaton, I., Dogruel, S., 2004. Pre-treatment of penicillin formulation effluent by advanced oxidation processes. Journal of Hazardous Materials B112, 105-113.

Arslan Alaton, I., Dogruel, S., Baykal, E., Gerone, G., 2004. Combined chemical and biological oxidation of penicillin formulation effluent. Journal of Environmental Management 73, 155-163.

Auerbach, E.A., Seyfried, E.E., McMahon, K.D., 2007. Tetracycline resistance genes in activated sludge wastewater treatment plants. Water Research 41, 1143-1151.

Backhaus, T., Grimme, L.H., 1999. The toxicity of antibiotic agents to the luminescent bacterium Vibrio fischeri. Chemosphere 38 , 3291-3301.

Balcıoglu, I.A., Otker, M., 2003. Treatment of pharmaceutical wastewater containing antibiotics by $\mathrm{O}_{3}$ and $\mathrm{O}_{3} / \mathrm{H}_{2} \mathrm{O}_{2}$ processes. Chemosphere 50, 85-95.

Batt, A.L., Kim, S., Aga, D.S., 2007. Comparison of the occurrence of antibiotics in four full-scale wastewater treatment plants with varying designs and operations. Chemosphere 68, 428-435.

Batt, A.L., Snow, D.D., Aga, D.S., 2006. Occurrence of sulphonamide antimicrobials in private water wells in Washington County, Idaho, USA. Chemosphere 64, 1963-1971.

Bautitz, I.R., Nogueira, R.F.P., 2007. Degradation of tetracycline by photo-Fenton process-solar irradiation and matrix effects. Journal of Photochemistry and Photobiology A: Chemistry 187, 33-39.

Bendz, D., Paxéus, N.A., Ginn, T.R., Loge, F.J., 2005. Occurrence and fate of pharmaceutically active compounds in the environment, a case study: Hoje River in Sweden. Journal of Hazardous Materials 122, 195-204.

Boehler, M., Zwickenpflug, B., Hollender, J., Ternes, T., Joss, A., Siegrist, H., 2012. Removal of micropollutants in municipal wastewater treatment plants by powder-activated carbon. Water Science and Technology 66, 2115-2121.

Boxall, A.B.A., 2004. The environmental side effects of medication. EMBO Reports 5, 1110-1116.

Brown, K.D., Kulis, J., Thomson, B., Chapman, T.H., Mawhinney, D.B., 2006. Occurrence of antibiotics in hospital, residential, and dairy effluent, municipal wastewater, and the Rio Grande in New Mexico. Science of the Total Environment 366, 772-783.

Carballa, M., Omil, F., Lema, J.M., Llompart, M., Garcia-Jares, C., Rodriguez, I., Gomez, M., Ternes, T., 2004. Behavior of pharmaceuticals, cosmetics and hormones in a sewage treatment plant. Water Research 38, 2918-2926.

Castiglioni, S., Pomati, F., Miller, K., Burns, B.P., Zuccato, E., Calamari, D., Neilan, B.A., 2008. Novel homologs of the multiple resistance regulator marA in antibioticcontaminated environments. Water Research 42, 4271-4280.

Cha, J.M., Yang, S., Carlson, K.H., 2006. Trace determination of $\beta$ lactam antibiotics in surface water and urban wastewater using liquid chromatography combined with electrospray tandem mass spectrometry. Journal of Chromatography A 1115, 46-57.

Choi, K.J., Kim, S.G., Kim, C.W., Kim, S.H., 2007. Determination of antibiotic compounds in water by on-line SPE-LC/MSD. Chemosphere 66, 977-984.

Clara, M., Strenn, B., Gans, O., Martinez, E., Kreuzinger, N., Kroiss, H., 2005. Removal of selected pharmaceuticals, fragrances and endocrine disrupting compounds in a membrane bioreactor and conventional wastewater treatment plants. Water Research 39, 4797-4807.

Costanzo, S.D., Murby, J., Bates, J., 2005. Ecosystem response to antibiotics entering the aquatic environment. Marine Pollution Bulletin 51, 218-223. 
Czekalski, N., Berthold, T., Caucci, S., Egli, A., Bürgmann, H., 2012. Increased levels of multiresistant bacteria and resistance genes after wastewater treatment and their dissemination into Lake Geneva, Switzerland. Frontiers in Microbiology 3 (106), 1-18.

Davies, J., Davies, D., 2010. Origins and evolution of antibiotic resistance. Microbiology and Molecular Biology Reviews 74 (3), 417-433.

De la Cruz, N., Giménez, J., Esplugas, S., Grandjean, D., de Alencastro, L.F., Pulgarín, C., 2012. Degradation of 32 emergent contaminants by UV and neutral photo-fenton in domestic wastewater effluent previously treated by activated sludge. Water Research 46, 1947-1957.

Diaz-Cruz, M.S., Lopez de Alda, M.J., Barcelo, D., 2003. Environmental behavior and analysis of veterinary and human drugs in soils, sediments and sludge. TrAC-Trends in Analytical Chemistry 22 (6), 340-351.

Dickenson, E.R.V., Drewes, J.E., Sedlak, D.L., Wert, E.C., Snyder, S.A., 2009. Applying surrogates and indicators to assess removal efficiency of trace organic chemicals during chemical oxidation of wastewaters. Environmental Science and Technology 43 (16), 6242-6247.

Dodd, M.C., Buffle, M., von Gunten, U., 2006. Oxidation of antibiotic molecules by aqueous ozone: moiety-specific reaction kinetics and application to ozone-based wastewater treatment. Environmental Science and Technology 40, 1969-1977.

Dodd, M.C., Kohler, H.E., Gunten, U.V., 2009. Oxidation of antibiotic compounds by ozone and hydroxyl radical: elimination of biological activity during aqueous ozonation processes. Environmental Science and Technology 43, $2498-2504$.

Dodd, M.C., 2012. Potential impacts of disinfection processes on elimination and deactivation of antibiotic resistance genes during water and wastewater treatment. Journal of Environmental Monitoring 14, 1754-1771. http://dx.doi.org/ 10.1039/c2em00006g.

Dolar, D., Gros, M., Rodriguez-Mozaz, S., Moreno, J., Comas, J., Rodriguez-Roda, I., Barceló, D., 2012. Removal of emerging contaminants from municipal wastewater with an integrated membrane system, MBR-RO. Journal of Hazardous Materials 239-240, 64-69. http://dx.doi.org/10.1016/ j.jhazmat.2012.03.029.

Drewes, J.E., 2008. Removal of Pharmaceutical Residues During Wastewater Treatment. In: Comprehensive Analytical Chemistry 50. Chapter 4.1.

Drewes, J.E., Bellona, C., Oedekoven, M., Xu, P., Kim, T.U., Amy, G., 2006. Rejection of wastewater-derived micropollutants in high-pressure membrane applications leading to indirect potable reuse. Environmental Progress 24 (4), 400-409.

Elmolla, E.S., Chaudhuri, M., 2011. The feasibility of using combined $\mathrm{TiO}_{2}$ photocatalysis-SBR process for antibiotic wastewater treatment. Desalination 272, 218-224.

Emery, R.J., Papadaki, M., Freitas dos Santos, L.M., Mantzavinos, D., 2005. Extent of sonochemical degradation and change of toxicity of a pharmaceutical precursor (triphenylphosphineoxide) in water as a function of treatment conditions. Environment International 31, 207-211.

Fatta-Kassinos, D., Hapeshi, E., Achilleos, A., Meric, S., Gros, M., Petrovic, M., Barcelo, D., 2010. Existence of pharmaceutical compounds in tertiary treated urban wastewater that is utilized for reuse applications. Water Resources Management 25, 1183-1193.

Fatta-Kassinos, D., Meric, S., Nikolaou, A., 2011a. Pharmaceutical residues in environmental waters and wastewater: current state of knowledge and future research. Analytical and Bioanalytical Chemistry 399, 251-275.
Fatta-Kassinos, D., Vasquez, M.I., Kümmerer, K., 2011b. Transformation products of pharmaceuticals in surface waters and wastewater formed during photolysis and advanced oxidation processes - degradation, elucidation of byproducts and assessment of their biological potency. Chemosphere 85, 693-709.

Froehner, K., Backhaus, T., Grimme, L.H., 2000. Bioassays with Vibrio fischeri for the assessment of delayed toxicity. Chemosphere 40, 821-828.

Gao, P., Munir, M., Xagoraraki, I., 2012. Correlation of tetracycline and sulfonamide antibiotics with corresponding resistance genes and resistant bacteria in a conventional municipal wastewater treatment plant. Science of the Total Environment 421-422, 173-183. http://dx.doi.org/10.1016/ j.scitotenv.2012.01.061.

Göbel, A., McArdell, C.S., Joss, A., Siegrist, H., Giger, W., 2007. Fate of sulfonamides, macrolides, and trimethoprim in different wastewater treatment technologies. Science of the Total Environment 372, 361-371.

Göbel, A., Thomsen, A., McArdell, C.S., Joss, A., Giger, W., 2005. Occurrence and sorption behavior of sulfonamides, macrolides, and trimethoprim in activated sludge treatment. Environmental Science and Technology 39, 3981-3989.

Golet, E.M., Alder, A.C., Giger, W., 2002. Environmental exposure and risk assessment of fluoroquinolone antibiotic agents in wastewater and river water of the Glatt Valley Watershed, Switzerland. Environmental Science and Technology 36, 3645-3651.

Golet, E.M., Xifra, I., Siegrist, H., Alder, A.C., Giger, W., 2003. Environmental exposure assessment of fluoroquinolone antibiotic agents from sewage to soil. Environmental Science and Technology 37, 3243-3249.

Goslich, R., Dillert, R., Bahnemann, D., 1997. Solar water treatment: principles and reactors. Water Science and Technology 35 (4), 137-148.

Gros, M., Petrovíc, M., Barceló, D., 2006. Development of a multiresidue analytical methodology based on liquid chromatography-tandem mass spectrometry (LC-MS/MS) for screening and trace level determination of pharmaceuticals in surface and wastewaters. Talanta 70, 678-690.

Guardabassi, L., Wong, D.M.A., Dalsgaard, A., 2002. The effects of tertiary wastewater treatment on the prevalence of antimicrobialresistant bacteria. Water Research 36, 1955-1964.

Gullberg, E., Cao, S., Berg, O.G., Ilbäck, C., Sandegren, L., Hughes, D., Andersson, D.I., 2012. Selection of resistant bacteria at very low antibiotic concentrations. PLoS Pathogens 7, 1-9.

Gulkowska, A., Leung, H.W., So, M.K., Taniyasu, S., Yamashita, N., Yeung, L.W.Y., Richardson, B.J., Lei, A.P., Giesy, J.P., Lam, P.K.S., 2008. Removal of antibiotics from wastewater by sewage treatment facilities in Hongkong and Shenzhen, China. Water Research 42, 395-403.

Hapeshi, E., Achilleos, A., Vasquez, M.I., Michael, C., Xekoukoulotakis, N.P., Mantzavinos, D., Kassinos, D., 2010. Drugs degrading photocatalytically: kinetics and mechanisms of ofloxacin and atenolol removal on titania suspensions. Water Research 44, 1737-1746.

Heberer, T., 2002. Occurrence, fate, and removal of pharmaceutical residues in the aquatic environment: a review of recent research data. Toxicology Letters 131, 5-17.

Hernández-Sancho, F., Molinos-Senante, M., Sala-Garrido, R., 2010. Economic valuation of environmental benefits from wastewater treatment processes: an empirical approach for Spain. Science of the Total Environment 408, 953-957.

Herrmann, J.M., Guillard, C., Pichat, P., 1993. Heterogeneous photocatalysis: an emerging technology for water treatment. Catalysis Today 17, 7-20. 
Hirsch, R., Ternes, T., Haberer, K., Kratz, K.L., 1999. Occurrence of antibiotics in the aquatic environment. Science of the Total Environment 225, 109-118.

Hollender, J., Singer, H., McArdell, C., 2008. Polar organic micropollutants in the water cycle. In: Hlavinek, P., et al. (Eds.), Dangerous Pollutants (Xenobiotics) in Urban Water Cycle. Springer, pp. 103-116.

Hollender, J., Zimmermann, S.G., Koepke, S., Krauss, M., McArdell, C.S., Ort, C., Singer, H., von Gunten, U., Siegrist, H., 2009. Elimination of organic micropollutants in a municipal wastewater treatment plant upgraded with a full-scale postozonation followed by sand filtration. Environmental Science and Technology 43, 7862-7869.

Homem, V., Santos, L., 2011. Degradation and removal methods of antibiotics from aqueous matrices - a review. Journal of Environmental Management 92, 2304-2347.

Huber, M.M., Göbel, A., Joss, A., Hermann, N., Loffler, D., McArdell, C.S., Ried, A., Siegrist, H., Ternes, T.A., von Gunten, U., 2005. Oxidation of pharmaceuticals during ozonation of municipal wastewater effluents: a pilot study. Environmental Science and Technology 39, 4290-4299.

Jelic, A., Gros, M., Ginebreda, A., Cespedes-Sanchez, R., Ventura, F., Petrovic, M., Barcelo, D., 2011. Occurrence, partition and removal of pharmaceuticals in sewage water and sludge during wastewater treatment. Water Research 45, 1165-1176.

Ji, L.G., Chen, W., Duan, L., Zhu, D., 2009. Mechanisms for strong adsorption of tetracycline to carbon nanotubes: a comparative study using activated carbon and graphite as adsorbents. Environmental Science and Technology 43, 2322-2327.

Jiao, S., Zheng, S., Yin, D., Wang, L., Chen, L., 2008. Aqueous photolysis of tetracycline and toxicity of photocatalytic products to luminescent bacteria. Chemosphere 73, 377-382.

Jones, O.A.H., Voulvoulis, N., Lester, J.N., 2001. Human pharmaceuticals in the aquatic environment a review. Environmental Science and Technology 22, 1383-1394.

Jones, O.A.H., Voulvoulis, N., Lester, J.N., 2007. The occurrence and removal of selected pharmaceutical compounds in a sewage treatment works utilising activated sludge treatment. Environmental Pollution 145 (3), 738-744.

Jordá, L.S.J., Martín, M.M.B., Gómez, E.O., Reina, A.C., Sánchez, I.M.R., López, J.L.C., Pérez, J.A.S., 2011. Economic evaluation of the photo-Fenton process. Mineralization level and reaction time: the keys for increasing plant efficiency. Journal of Hazardous Materials 186, 1924-1929.

Joss, A., Kellera, E., Aldera, A.C., Göbel, A., McArdell, C.S., Ternes, T., Siegrista, H., 2005. Removal of pharmaceuticals and fragrances in biological wastewater treatment. Water Research 39, 3139-3152.

Karthikeyan, K.G., Meyer, M.T., 2006. Occurrence of antibiotics in wastewater treatment facilities in Wisconsin, USA. Science of the Total Environment 361, 196-207.

Kasprzyk-Hordern, B., Dinsdale, R.M., Guwy, A.J., 2009. The removal of pharmaceuticals, personal care products, endocrine disruptors and illicit drugs during wastewater treatment and its impact on the quality of receiving waters. Water Research 43, 363-380.

Katsoyiannis, I.A., Canonica, S., Gunten, U., 2011. Efficiency and energy requirements for the transformation of organic micropollutants by ozone, $\mathrm{O}_{3} / \mathrm{H}_{2} \mathrm{O}_{2}$ and $\mathrm{UV} / \mathrm{H}_{2} \mathrm{O}_{2}$. Water Research 45, 3811-3822.

Kemper, N., 2008. Vetererinary antibiotics in the aquatic and terrestrial environment. Ecological Indicators 8, 1-13.

Khan, S.J., Ongerth, J.E., 2005. Occurrence and removal of pharmaceuticals at an Australian sewage treatment plant. Water 32 (4), 80-85.

Kim, I., Yamashita, N., Tanaka, H., 2009. Performance of UV and $\mathrm{UV} / \mathrm{H}_{2} \mathrm{O}_{2}$ processes for the removal of pharmaceuticals detected in secondary effluent of a sewage treatment plant in Japan. Journal of Hazardous Materials 166, 1134-1140.

Kim, S., Eichhorn, P., Jensen, J.N., Weber, A.S., Aga, D., 2005. Removal of antibiotics in wastewater: effect of hydraulic and solid retention times on the fate of tetracycline in the activated sludge process. Environmental Science and Technology 39, 5816-5823.

Kim, Y., Choi, K., Jung, J., Park, S., Kim, P.G., Park, J., 2007. Aquatic toxicity of acetaminophen, carbamazepine, cimetidine, diltiazem and six major sulfonamides, and their potential ecological risks in Korea. Environment International 33, 370-375.

Kimura, K., Toshima, S., Amy, G., Watanabe, Y., 2004. Rejection of neutral endocrine disrupting compounds (EDCs) and pharmaceutical active compounds (PhACs) by RO membranes. Journal of Membrane Science 245, 71-78.

Klamerth, N., Rizzo, L., Malato, S., Maldonado, M.I., Aguera, A., Fernández-Alba, A.R., 2010. Degradation of fifteen emerging contaminants at $\mu \mathrm{L} \mathrm{L}^{-1}$ initial concentrations by mild solar photo-Fenton in MWTP effluents. Water Research 44, 545-554.

Klavarioti, M., Mantzavinos, D., Kassinos, D., 2009. Removal of residual pharmaceuticals from aqueous systems by advanced oxidation processes. Environment International 35, 402-417.

Kolpin, D.W., Furlong, E.T., Meyer, M.T., Thurman, E.M., Zaugg, S.D., Barber, L.B., Buxton, H.T., 2002. Pharmaceuticals, hormones, and other organic wastewater contaminants in U.S. streams, 1999-2000: a national reconnaissance. Environmental Science and Technology 36, 1202-1211.

Kosutíc, K., Dolar, D., Asperger, D., Kunst, B., 2007. Removal of antibiotics from a model wastewater by RO/NF membranes. Separation and Purification Technology 53, 244-249.

Kovalova, L., Siegrist, H., Singer, H., Wittmer, A., McArdell, C.S., 2012. Hospital wastewater treatment by membrane bioreactor: performance and efficiency for organic micropollutant elimination. Environmental Science and Technology 46, 1536-1545.

Kümmerer, K., 2009. Antibiotics in the aquatic environment a review - Part II. Chemosphere 75, 435.

Lange, F., Cornelissen, S., Kubac, D., Sein, M.M., von Sonntag, J., Hannich, C.B., Golloch, A., Heipieper, H.J., Moder, M., von Sonntag, C., 2006. Degradation of macrolide antibiotics by ozone: a mechanistic case study with clarithromycin. Chemosphere 65 (1), 17-23.

Längin, A., Alexy, R., König, A., Kümmerer, K., 2009. Deactivation and transformation products in biodegradability testing of $\beta$ lactams amoxicillin and piperacillin. Chemosphere 75, 347-354.

Le Corre, S.K., Ort, C., Kateley, D., Allen, B., Escher, B.I., Keller, J., 2012. Consumption-based approach for assessing the contribution of hospitals towards the load of pharmaceutical residues in municipal wastewater. Environment International 45, 99-111.

Lee, Y., Zimmermann, S.G., Kieu, A.T., von Gunten, U., 2009. Ferrate $(\mathrm{Fe}(\mathrm{VI}))$ application for municipal wastewater treatment: a novel process for Simultaneous micropollutant oxidation and phosphate removal. Environmental Science and Technology 43 (10), 3831-3838.

Legrini, O., Oliveros, E., Braun, A.M., 1993. Photochemical processes for water treatment. Chemical Reviews 93, 671-698.

Le-Minh, N., Khan, S.J., Drewes, J.E., Stuetz, R.M., 2010. Fate of antibiotics during municipal water recycling treatment processes. Water Research 44, 4295-4323.

Li, B., Zhang, T., 2011. Mass flows and removal of antibiotics in two municipal wastewater treatment plants. Chemosphere 83, 1284-1289. http://dx.doi.org/10.1016/ j.chemosphere.2011.03.002.

Li, B., Zhang, T., Xua, Z., Fang, H.H.P., 2009. Rapid analysis of 21 antibiotics of multiple classes in municipal wastewater using 
ultra performance liquid chromatography-tandem mass spectrometry. Analytica Chimica Acta 645, 64-72.

Li, S., Li, X., Wang, D., 2004. Membrane (RO-UF) filtration for antibiotic wastewater treatment and recovery of antibiotics. Separation and Purification Technology 34, 109-114.

Lin, A.Y.C., Yu, T.H., Lateef, S.K., 2009a. Removal of pharmaceuticals in secondary wastewater treatment processes in Taiwan. Journal of Hazardous Materials 167, 1163-1169.

Lin, A.Y.C., Lin, C., Chiou, J., Hong, P.K.A., 2009b. $\mathrm{O}_{3}$ and $\mathrm{O}_{3} / \mathrm{H}_{2} \mathrm{O}_{2}$ treatment of sulfonamide and macrolide antibiotics in wastewater. Journal of Hazardous Materials 171, 452-458.

Lindberg, R.H., Wennberg, P., Johansson, M.I., Tysklind, M., Andersson, B.A.V., 2005. Screening of human antibiotic. Substances and determination of weekly mass flows in five sewage treatment plants in Sweden. Environmental Science and Technology 39, 3421-3429.

Litter, M.I., 2005. Introduction to photochemical advanced oxidation processes for water treatment. Environmental Chemistry 2 (Pt. M), 325-366.

Loffler, D., Ternes, T.A., 2003. Analytical method for the determination of the aminoglycoside gentamicin in hospital wastewater via liquid chromatography electrospray-tandem mass spectrometry. Journal of Chromatography A 1000 (1-2), 583-588.

Loganathan, B., Phillips, M., Mowery, H., Jones-Lepp, T.L., 2009. Contamination profiles and mass loadings of macrolide antibiotics and illicit drugs from a small urban wastewater treatment plant. Chemosphere 75, 70-77.

Macrì, A., Stazi, A.V., Dojmi di Delupis, G., 1988. Acute toxicity of furazolidone on Artemia salina, Daphnia magna, and Culex pipiens molestus larvae. Ecotoxicology and Environmental Safety 16, 90-94.

Mahamuni, N.N., Adewuyi, Y.G., 2010. Advanced oxidation processes (AOPs) involving ultrasound for wastewater treatment: a review with emphasis on cost estimation. Ultrasonics Sonochemistry 17, 990-1003.

Mahugo-Santana, C., Sosa-Ferrera, Z., Torres-Padrón, M.E., Santana-Rodríguez, J.J., 2010. Analytical methodologies for the determination of nitroimidazole residues in biological and environmental liquid samples: a review. Analytica Chimica Acta 665, 113-122.

Malato, S., Fernández-Ibáñez, P., Maldonado, M.I., Blanco, J., Gernjak, W., 2009. Decontamination and disinfection of water by solar photocatalysis: recent overview and trends. Catalysis Today 147, 1-59.

McArdell, C.S., Molnar, E., Suter, M.J.F., Giger, W., 2003. Occurrence and fate of macrolide antibiotics in wastewater treatment plants and in the Glatt Valley Watershed, Switzerland. Environmental Science and Technology 37, 5479-5486.

McArdell, C.S., Kovalova, L., Siegrist, H., Kienle, C., Moser, R., Schwartz, T., 2011. Input and Elimination of Pharmaceuticals and Disinfectants from Hospital Wastewater. Final project report. Eawag, Duebendorf, Switzerland. accessible at. http://tinyurl.com/eawag-spitalabwasser.

Melero, J.A., Calleja, G., Martinez, F., Molina, R., Pariente, M.I., 2007. Nanocomposite $\mathrm{Fe}_{2} \mathrm{O}_{3} / \mathrm{SBA}-15$ : an efficient and stable catalyst for the catalytic wet peroxidation of phenolic aqueous solutions. Chemical Engineering Journal 131, 245-256.

Miao, X.S., Bishay, F., Chen, M., Metcalfe, C.D., 2004. Occurrence of antimicrobials in the final effluents of wastewater treatment plants in Canada. Environmental Science and Technology 38, 3533-3541.

Michael, I., Hapeshi, E., Michael, C., Fatta-Kassinos, D., 2010. Solar Fenton and solar $\mathrm{TiO}_{2}$ catalytic treatment of ofloxacin in secondary treated effluents: evaluation of operational and kinetic parameters. Water Research 44, 5450-5462.
Michael, I., Hapeshi, E., Osorio, V., Pèrez, S., Petrović, M., Zapata, A., Malato, S., Barceló, D., Fatta-Kassinos, D., 2012a. Solar photocatalytic treatment of trimethoprim in four environmental matrices at a pilot scale: transformation products and ecotoxicity evaluation. Science of the Total Environment 430, 167-173.

Michael, I., Hapeshi, E., Michael, C., Varela, A.R., Kyriakou, S., Manaia, C.M., Fatta-Kassinos, D., 2012b. Solar Fenton process on the abatement of antibiotics at a pilot plant scale: degradation kinetics, ecotoxicity and phytotoxicity assessment and removal of antibiotic resistant enterococci. Water Research 46, 5621-5634.

Migliore, L., Cozzolino, S., Fiori, M., 2003. Phytotoxicity to and uptake of enrofloxacin in crop plants. Chemosphere 52, 1233-1244.

Morse, A., Jackson, A., 2004. Fate of amoxicillin in two water reclamation systems. Water, Air, \& Soil Pollution 157 (1-4), 117-132.

Munter, R., 2001. Advanced oxidation processes-current status and prospects. Proceedings of the Estonian Academy of Sciences Chemistry 50, 59-80.

Naddeo, V., Meric, S., Kassinos, D., Belgiorno, V., Guida, M., 2009. Fate of pharmaceuticals in contaminated urban wastewater effluent under ultrasonic irradiation. Water Research 43, 4019-4027.

Nakada, N., Shinohara, H., Murata, A., Kiri, K., Managakia, S., Sato, N., Takada, H., 2007. Removal of selected pharmaceuticals and personal care products (PPCPs) and endocrine-disrupting chemicals (EDCs) during sand filtration and ozonation at a municipal sewage treatment plant. Water Research 41, 4373-4382.

Pailler, J.Y., Krein, A., Pfister, L., Hoffmann, L., Guignard, C., 2009. Solid phase extraction coupled to liquid chromatographytandem mass spectrometry analysis of sulfonamides, tetracyclines, analgesics and hormones in surface water and wastewater in Luxembourg. Science of the Total Environment 407, 4736-4743.

Parsons, S., 2004. Advanced Oxidation Processes for Water and Wastewater Treatment. IWA Publishing.

Peng, X., Wang, Z., Kuang, W., Tan, J., Li, K., 2006. A preliminary study on the occurrence and behavior of sulfonamides, ofloxacin and chloramphenicol antimicrobials in wastewaters of two sewage treatment plants in Guangzhou, China. Science of the Total Environment 371, 314-322.

Perez, S., Eichhorn, P., Aga, D.S., 2005. Evaluating the biodegradability of sulfamethazine, sulfamethoxazole, sulfathiazole and trimethoprim at different stages of sewage treatment. Environmental Toxicology and Chemistry 24 (6), 1361-1367.

Putra, E.K., Pranowo, R., Sunarso, J., Indraswati, N., Ismadji, S., 2009. Performance of activated carbon and bentonite for adsorption of amoxicillin from wastewater: mechanisms, isotherms and kinetics. Water Research 43, 2419-2430.

Radjenovic, J., Godehardt, M., Petrovic, M., Hein, A., Farre, M., Jekel, M., Barcelo, D., 2009a. Evidencing generation of persistent ozonation products of antibiotics roxithromycin and trimethoprim. Environmental Science and Technology 43, 6808-6815.

Radjenovic, J., Petrovic, M., Barcelo, D., 2009b. Fate and distribution of pharmaceuticals in wastewater and sewage sludge of the conventional activated sludge (CAS) and advanced membrane bioreactor (MBR) treatment. Water Research 43, 831-841.

Reif, R., Suárez, S., Omil, F., Lema, J.M., 2008. Fate of pharmaceuticals and cosmetic ingredients during the operation of a MBR treating sewage. Desalination 221, 511-517. 
Renew, J.E., Huang, C.H., 2004. Simultaneous determination of fluoroquinolone, sulfonamide, and trimethoprim antibiotics in wastewater using tandem solid phase extraction and liquid chromatography-electrospray mass spectrometry. Journal of Chromatography A 1042, 113-121.

Richardson, S.D., Ternes, T.A., 2011. Water analysis: emerging contaminants and current issues. Analytical Chemistry 83 (12), 4614-4648.

Rivera-Utrilla, J., Prados-Joya, G., Sánchez-Polo, M., FerroGarcía, M.A., Bautista-Toledo, I., 2009. Removal of nitroimidazole antibiotics from aqueous solution by adsorption/bioadsorption on activated carbon. Journal of Hazardous Materials 170, 298-305.

Rizzo, L., 2011. Bioassays as a tool for evaluating advanced oxidation processes in water and wastewater treatment. Water Research 45, 4311-4340.

Rizzo, L., Meric, S., Guida, M., Kassinos, D., Belgiorno, V., 2009. Heterogenous photocatalytic degradation kinetics and detoxification of an urban wastewater treatment plant effluent contaminated with pharmaceuticals. Water Research 43, 4070-4078.

Roberts, P.H., Thomas, K.V., 2006. The occurrence of selected pharmaceuticals in wastewater effluent and surface waters of the lower Tyne catchment. Science of the Total Environment 356, 143-153.

Robertson, P.K.J., 1996. Semiconductor photocatalysis: an environmentally acceptable alternative production technique and effluent treatment process. Journal of Cleaner Production 4 (34), 203-212.

Rogers, H.R., 1996. Sources, behaviour and fate of organic contaminants during sewage treatment and in sewage sludges. Science of the Total Environment 185, 3-26.

Rosal, R., Rodríguez, A., Perdigón-Melón, J.A., Petre, A., GarcíaCalvo, E., Gómez, M.J., Aguera, A., Fernández-Alba, A.R., 2010. Occurrence of emerging pollutants in urban wastewater and their removal through biological treatment followed by ozonation. Water Research 44, 578-588.

Rosario-Ortiz, F.L., Wert, E.C., Snyder, S.A., 2010. Evaluation of $\mathrm{UV} / \mathrm{H}_{2} \mathrm{O}_{2}$ treatment for the oxidation of pharmaceuticals in wastewater. Water Research 44, 1440-1448.

Ryan, C.C., Tan, D.T., Arnold, W.A., 2011. Direct and indirect photolysis of sulfamethoxazole and trimethoprim in wastewater treatment plant effluent. Water Research 45, 1280-1286.

Sahar, E., David, I., Gelman, Y., Chikurel, H., Aharoni, A., Messalem, R., Brenner, A., 2010. The use of RO to remove emerging micropollutants following CAS/UF or MBR treatment of municipal wastewater. Desalination 273 (1), 142-147.

Santos, A., Yustos, P., Rodriguez, S., Simon, E., Garcia-Ochoa, F., 2007. Abatement of phenolic mixtures by catalytic wet oxidation enhanced by Fenton's pretreatment: effect of $\mathrm{H}_{2} \mathrm{O}_{2}$ dosage and temperature. Journal of Hazardous Materials 146, 595-601.

Saritha, P., Aparna, C., Himabindu, V., Anjaneyulu, Y., 2007. Comparison of various advanced oxidation processes for the degradation of 4-chloro-2nitrophenol. Journal of Hazardous Materials 149, 609-614.

Schafer, A.I., Kalinowski, J., Puhler, A., 1994. Increased fertility of Corynebacterium glutamicum recipients in intergeneric matings with Escherichia coli after stress exposure. Applied and Environmental Microbiology 60 (2), 756-759.

Schiavello, M., 1993. Some working principles of heterogeneous photocatalysis by semiconductors. Electrochimicha Acta 38 (1), 11-14.

Schwartz, T., Kohnen, W., Jansen, B., Obst, U., 2006. Detection of antibiotic-resistant bacteria and their resistance genes in wastewater, surface water and drinking water biofilms. FEMS Microbiology Ecology 43 (3), 325-355.
Serrano, D., Suárez, S., Lema, J.M., Omil, F., 2011. Removal of persistent pharmaceutical micropollutants from sewage by addition of PAC in a sequential membrane bioreactor. Water Research 45, 5323-5333.

Snyder, A.S., Westerhoff, P., Yoon, Y., Sedlak, D.L., 2003. Pharmaceuticals, personal care products, and endocrine disruptors in water: implications for the water industry. Environmental Engineering Science 20 (5), 449-469.

Spongberg, A.L., Witter, J.D., 2008. Pharmaceutical compounds in the wastewater process stream in Northwest Ohio. Science of the Total Environment 397, 148-157.

Sui, Q., Huang, J., Deng, S., Yu, G., Fan, Q., 2010. Occurrence and removal of pharmaceuticals, caffeine and DEET in wastewater treatment plants of Beijing, China. Water Research 44, 417-426.

Tadkaew, N., Sivakumar, M., Khan, S.J., McDonald, J.A., Nghiem, L.D., 2011. Effect of mixed liquor $\mathrm{pH}$ on the removal of trace organic contaminants in a membrane bioreactor. Bioresource Technology 101, 1494-1500.

Tambosi, J.L., de Sena, R.F., Favier, M., Gebhardt, W., José, H.J., Schröder, H.F., Moreira, R.F.P.M., 2010. Removal of pharmaceutical compounds in membrane bioreactors (MBR) applying submerged membranes. Desalination 26, 148-156.

Tekin, H., Bilkay, O., Ataberk, S.S., Balta, T.H., Ceribasi, I.H., Sanin, F.D., 2006. Use of Fenton oxidation to improve the biodegradability of a pharmaceutical wastewater. Journal of Hazardous Materials 136, 258-265.

Ternes, T.A., Stuber, J., Herrmann, N., McDowell, D., Ried, A., Kampmann, M., Teiser, B., 2003. Ozonation: a tool for removal of pharmaceuticals, contrast media and musk fragrances from wastewater? Water Research 37, 1976-1982.

Ternes, T.A., Bonerz, M., Herrmann, N., Teiser, B., Andersen, H.R., 2007. Irrigation of treated wastewater in Braunschweig, Germany: an option to remove pharmaceuticals and musk fragrances. Chemosphere 66, 894-904.

Thomulka, K.W., McGee, D.J., 1993. Detection of biohazardous materials in water by measuring bioluminescence reduction with the marine organism Vibrio harveyi. Journal of Environmental Science \& Health Part A 28, 2153-2166.

Trovó, A.G., Melo, S.A.S., Nogueira, R.F.P., 2008. Photodegradation of the pharmaceuticals amoxicillin, bezafibrate and paracetamol by the photo-Fenton process - application to sewage treatment plant effluent. Journal of Photochemistry and Photobiology A: Chemistry 198, 215-220.

Watkinson, A.J., Murbyc, E.J., Costanzoa, S.D., 2007. Removal of antibiotics in conventional and advanced wastewater treatment: implications for environmental discharge and wastewater recycling. Water Research 41, 4164-4176.

Watkinson, A.J., Murbyd, E.J., Kolpin, D.W., Costanzof, S.D., 2009. The occurrence of antibiotics in an urban watershed: from wastewater to drinking water. Science of the Total Environment 407, 2711-2723.

Westerhoff, P., Yoon, Y., Snyder, S., Wert, E., 2005. Fate of endocrine-disruptor, pharmaceutical, and personal care product chemicals during simulated drinking water treatment processes. Environmental Science and Technology 39, 6649-6663.

Wollenberger, L., Halling-Sorensen, B., Kusk, K.O., 2000. Acute and chronic toxicity of veterinary antibiotics to Daphnia magna. Chemosphere 40, 723-730.

Xekoukoulotakis, N.P., Drosou, C., Brebou, C., Chatzisymeon, E., Hapeshi, E., Fatta-Kassinos, D., Mantzavinos, D., 2010. Kinetics of UV-A/ $/ \mathrm{TiO}_{2}$ photocatalytic degradation and mineralization of the antibiotic sulfamethoxazole in aqueous matrices. Catalysis Today 161, 163-168.

Xia, S., Jia, R., Feng, F., Xie, K., Li, H., Jing, D., Xu, X., 2012. Effect of solids retention time on antibiotics removal performance and microbial communities in an A/O-MBR process. Bioresource Technology 106, 36-43. 
Xiao, Y., Chang, H., Jia, A., Hu, J., 2008. Trace analysis of quinolone and fluoroquinolone antibiotics from wastewaters by liquid chromatography - electrospray tandem mass spectrometry. Journal of Chromatography A 1214, 100-108.

Xu, P., Drewes, J.E., Kim, T.U., Bellona, C., Amy, G., 2006. Effect of membrane fouling on transport of organic contaminants in NF/RO membrane applications. Journal of Membrane Science 279 (1-2), 165-175.

Xu, W., Zhang, G., Li, X., Zou, S., Li, P., Hu, Z., Li, J., 2007. Occurrence and elimination of antibiotics at four sewage treatment plants in the Pearl River Delta (PRD), South China. Water Research 41, 4526-4534.

Yang, S., Carlson, K.H., 2004. Solid-phase extraction-highperformance liquid chromatography-ion trap mass spectrometry for analysis of trace concentrations of macrolides antibiotics in natural and waste water matrices. Journal of Chromatography A 1038, 141-155.

Yang, S., Cha, J., Carlson, K., 2005. Simultaneous extraction and analysis of 11 tetracycline and sulfonamide antibiotics in influent and effluent domestic wastewater by solid-phase extraction and liquid chromatography-electrospray ionization tandem mass spectrometry. Journal of Chromatography A 1097, 40-53.

Yang, Y., Wang, P., Shi, S., Liu, Y., 2009. Microwave enhanced Fenton-like process for the treatment of high concentration pharmaceutical wastewater. Journal of Hazardous Materials 168, 238-245.
Yargeau, V., Leclair, C., 2008. Impact of operating conditions on decomposition of antibiotics during ozonation: a review. Ozone: Science and Engineering 30, 175-188.

Yu, T., Lin, A.Y., Lateef, S.K., Lin, C., Yang, P., 2009. Removal of antibiotics and non-steroidal anti-inflammatory drugs by extended sludge age biological process. Chemosphere 77, 175-181.

Yuan, F., Hu, C., Hu, X., Wie, D., Chen, Y., Qu, J., 2011. Photodegradation and toxicity changes of antibiotics in UV and $\mathrm{UV} / \mathrm{H}_{2} \mathrm{O}_{2}$ process. Journal of Hazardous Materials 185, 1256-1263.

Zhang, G., Ji, S., Xi, B., 2006. Feasibility study of treatment of amoxillin wastewater with a combination of extraction, Fenton oxidation and reverse osmosis. Desalination 196, 32-42.

Zhang, Y., Marrs, C.F., Simon, C., Xi, C., 2009. Wastewater treatment contributes to selective increase of antibiotic resistance among Acinetobacter spp. Science of the Total Environment 407, 3702-3706.

Zorita, S., Mårtensson, L., Mathiasson, L., 2009. Occurrence and removal of pharmaceuticals in a municipal sewage treatment system in the south of Sweden. Science of the Total Environment 407, 2760-2770.

Zuccato, E., Castiglioni, S., Bagnati, R., Melis, M., Fanelli, R., 2010. Source, occurrence and fate of antibiotics in the Italian aquatic environment. Journal of Hazardous Materials 179 1042-1048. 